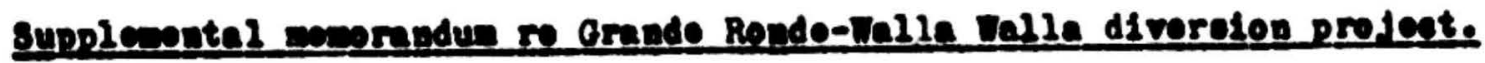

Genpliet ith othor prolects. The orande Ronde-Weile Walle diverolon project 10 eompetitive ath propoeed power and Irrigation dovelopent on the Snako-Coluabia

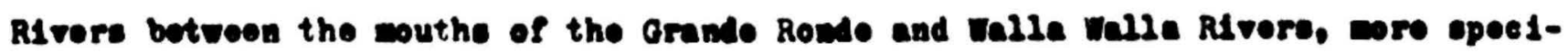
P1cally between belwater fren the proposed Unat12la den and backeter frov the propoed Dry Gulch Raplde site on the Snake RIver (Se0 W.S.P. 657, D. 256 ). Aesuring that the Unatilie dan 10 conot ruoted to an altitude of 350 foot, and tho Dry Guleh Rapide dan to an altitude of 730 foot, the 1000 arinend to tho sacke-

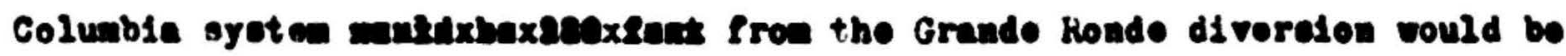
neacured by the aindre flow of the Grende Ronde develeped through seo soot of head. If other eltes on the salke River should be propoeed to ut1lise the full avalleble head belor the wouth of the Grande Rotde (Multude apprex. 820 foot), .

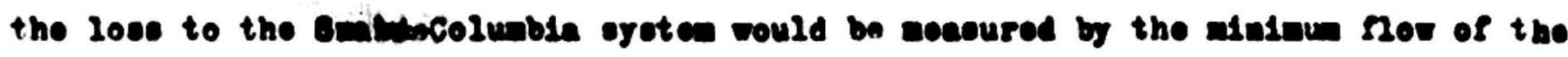
Grande Ronde developed through 460 foet of head.

However, the lose to the smake-Colubble oyetce vould probably Invelve porar

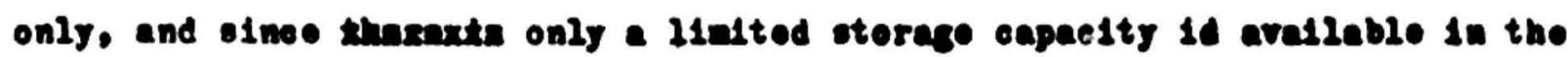
Snake River below the eouth of the Grande Ronde, the 20 es would be wo greater

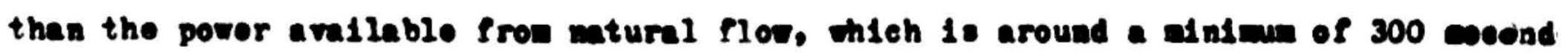
foet. If 300 eceond-foot were ut1l1sed through the full arallable head of 46 J foot It would derelop 11,000 K.P., or 8,300 K.it. of prine power. That enout of pover wat therefor be subtracted fron the 29,000 K. W. erodsted to the Grande Ronde-

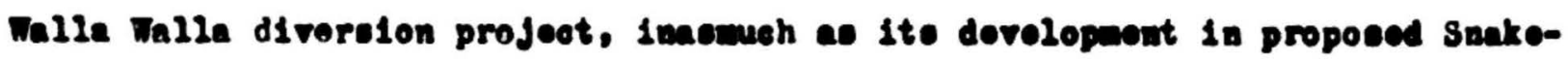
Columbla projects would ontail no addit1onal cost. Inotallatione at the proposed

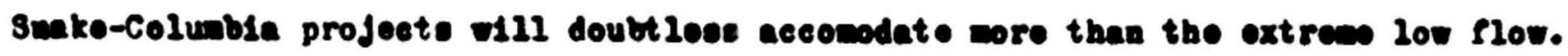

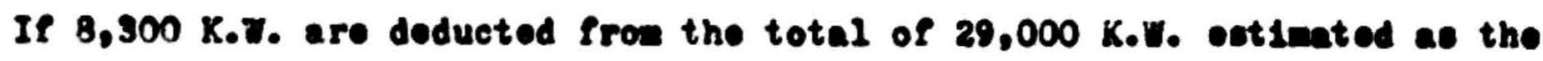
Q100 capaelty of the Grande Rondo-lalle Falle projeet under Plas II, the reandalas power, properly erodited to the projeet, $1020,700 \mathrm{K.W}$.

The Grande Ronde-walla Walle divereion projeot should not bo coneldered es 


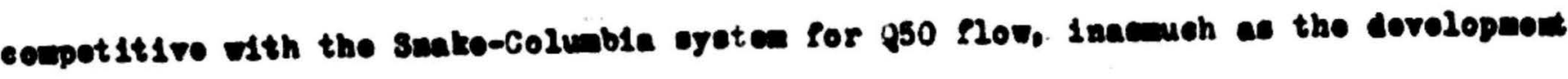
of pSo Plow would ontall addit1onl lastellations of conparable coot wothor ut1l-

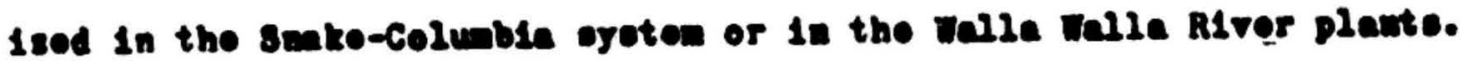

The 1000 to natgation on the snato-Golunbla River fron the propoecd diverelon would w nogliglble, elnee the ont1ro etrean mon fully doreleped would probably be elneknter.

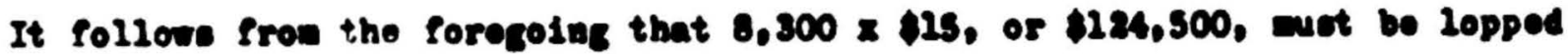

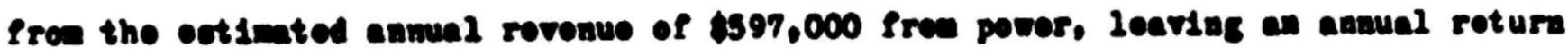

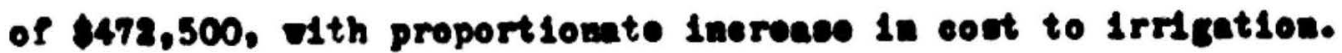

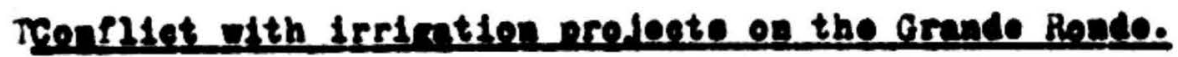

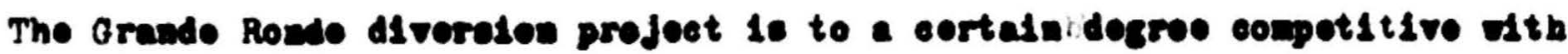
proposed Irrigetion projeete in the upper Grande Roade velloy. Aecerdlas to the

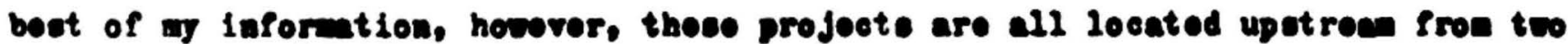
geglag etetione in the bala, one on the Grande Ronde near La Grande, the other on Gathoriso Crook wear Un10n. The total run-off rocorded at these two etatione 10

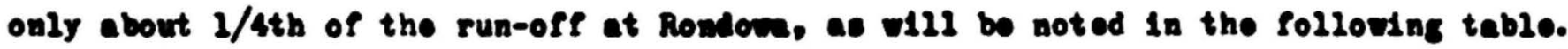
Gountive museoff in sere foet at etetion in the Grande Ronde bals.

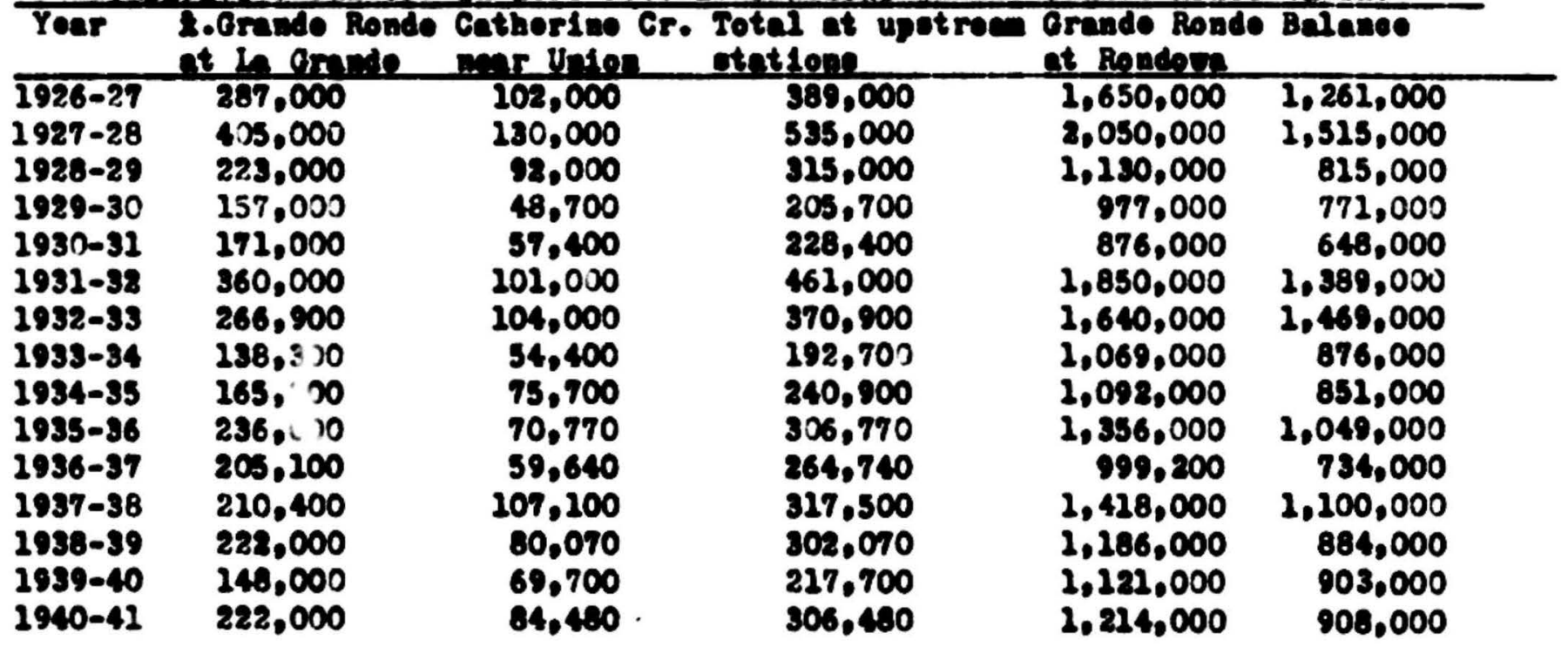


sooudng that all run-off at the two upotrece otatione wore stored, which 10

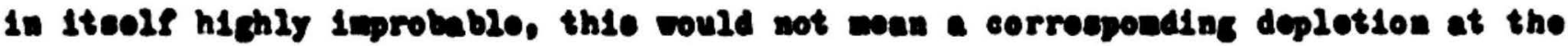

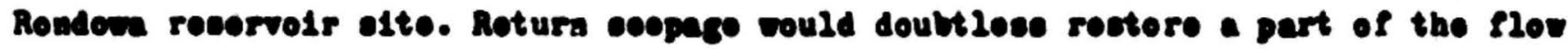
at Rowdowe. How much water vould I1nd ito wey back to tho rivor 10 a enjor ground weter problea, but it ea probably be eatimated at a conoldorable porcentego.

It 1. further epparent that even at the present t1a thore 10 very $11 t+20$ diecharge In the Grande Ronde at the etat1on near ia Grande durfag the erdt1eal nonthe of Auguet and Sopterbor. The gaglag otation reeord ohowe that the aean run-eff for Auguet during the 16-year poriod fron 2925 to 1941 ve 1,174 aere seot, and for Septonber. 2453 aere fect. Corroopondlas values for d1scharge ere a ean of 10 vocend-foet for Auguet, and a nean of 24 second-foct for septcober. It secen vory doubtful, therefor, that the masme poseible storage of water in the uppor

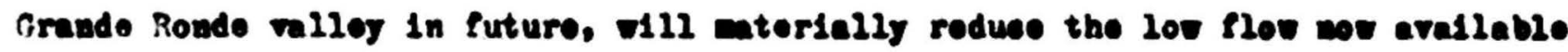
at Rondow. On the other hand, roture soopage from additional arees brought undor 1 rrigation in the future, wy quite poseibly ibereace the 100 nov nov avallable at Roadow.

If proposed reservoirs in the upper Grande Ronde basin ere to be operated al00 for flood coutrol, whlch, I undoretand to be the plen, otorege vould probably not begin until late viuter or carly opring, whon the hoevy run-off bocdne. If ouch 10 the plaw. future otorage in the uppor bein should not effect advorsely the value of the proposed divereion project for prine pocer.

The exteat to wich future upetrea otorage odll bo la confliet ifth the

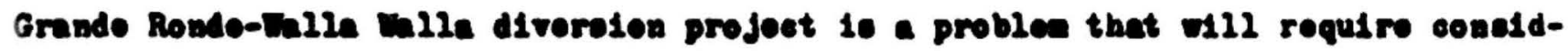
orable otudy. but a brief rovien of evilable discharge roeorde ladicatee that the fulleot developmet of upotran etorage eltee would net eorlouely confliet alth the proposed diverelon project if the two plane are proporly coordinated.

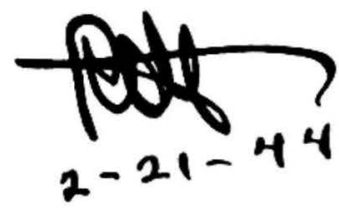




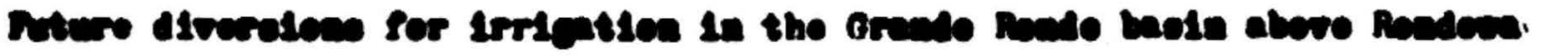

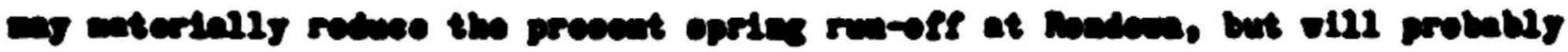

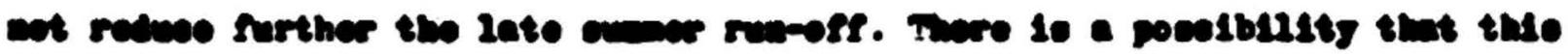

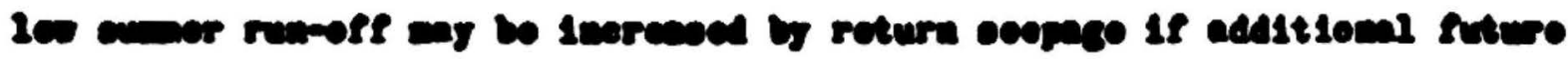

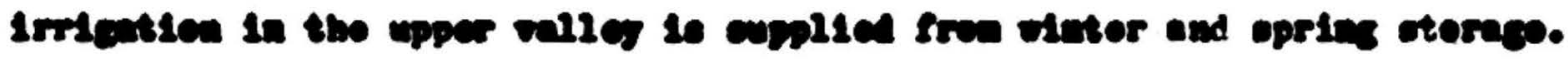

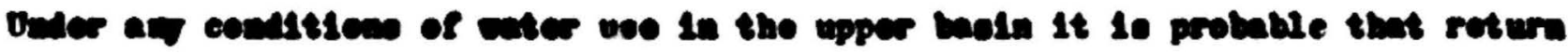

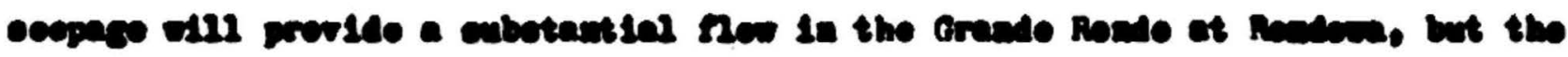

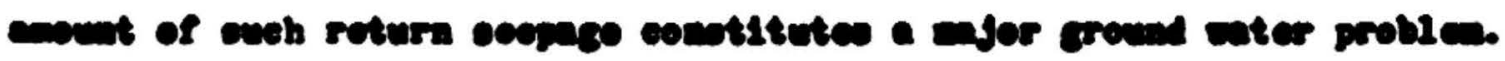

\section{Remint renere.}

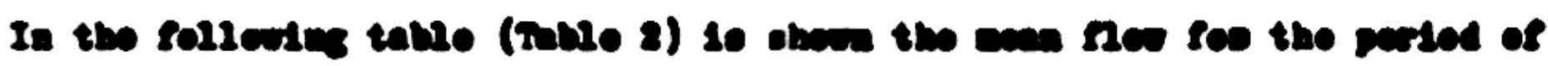

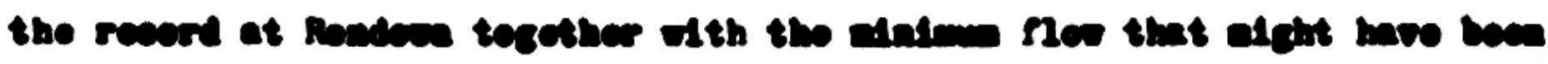

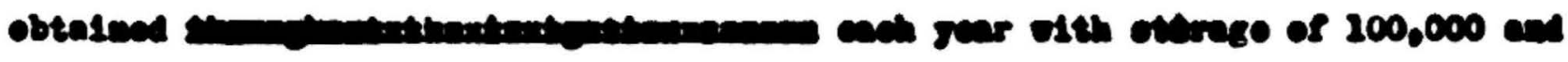
200,000 eare sent. 


\section{Tebre 2}

Matural ileoharge of the Grande Ronde River at Rondowa, Orogen, and regulated flow obtalnable by otorage of 100,000 acre foet and 200,000 acre foot

Iear Nural nor in socond reat Regulated now in Second Foet Keas KInimue 100,000 ecro foot 200,000 ecro foet

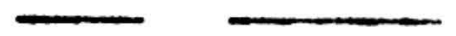
of otorage

of storen.

\section{6-27}

$1927-28$

2,280

468

$1928-29$

2,830

470

1929-30

2,560

353

1930-31

1,360

310

1.210

254

1931-32

2,550

301

1932-33

2,260

424

1933-34

1,477

300

1934-35

1,508

304

1935-36

1,868

256

1936-37

1,380

230

1037-38

1938-39

10958

308

1,638

335

$1939-40$

1,544

1940-41

1,677

260

1942-42

8.323

458

$1942-43$

2,953

439

800

25

ns

660

660

870

840

670

580

580

810

760

760

950
1,020

980

940

860

860

1,100

1,090

900

800

800

1,070

2,030

1,030

1,170

Aro. ziose

In Fable 3 which followe below, the conetant flow that could have beea matatalned throughout the irrigation season, Apr1l to Soptember, incluelve, 18 wown together with the mintmu notural flow that occurred in each year of the record. In ell years a minimu flow of 300 second feet could have been maintained for power purposes by reguletion. It will be noted from this table that e conotant flow of 1,000 second feet for irrigation might have boen maintained in a.11 years of the rocord but two (1931 and 1936), and that only atnor deflciency would have occurred in thoee yeara. 
Regulated flow evailable during irrigetion seeson and minimum flow avallable for power, aseuming storege of $100,000 \mathrm{~A} . \mathrm{F}$.

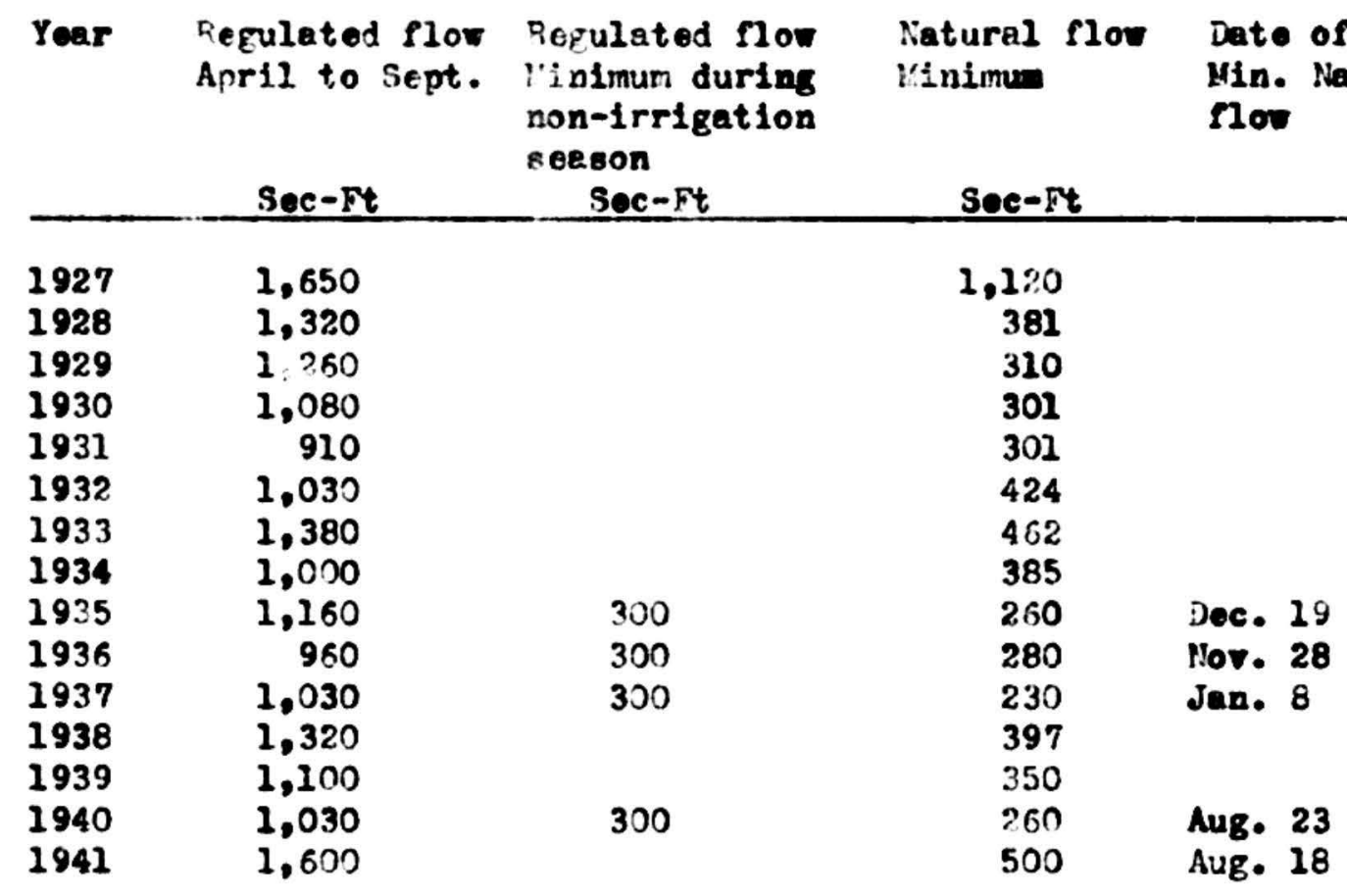

Although the gbove tobulation show that 1,000 second feet vould heve been Qveilable for Irrigation in all but two yesrs of the record, delivery vould have been limited by the size of the tunnel and could not have been made on en irrigation demend schedule. However some degree of regulation to adapt the rate of delivery to irrigation demand would be possible through reservoir head. In general the period of frestest Irrigation demend corresponde to the period of high reservoir stage.

\section{Arailable Storage}

A rough eetimate of avilable storage on the Erande Ronde liver can be made from a reconnaiegance survey of the Yallowa River wilich shows a part of the area within the proposed Rondova reservoir site. It is roughly estimated that atorage capecity of 150,000 acre feet could be developed on the Grande Ronde and Wallowe Rivers by the construction of a dam 250 feet high at the 
Sweop Creok dan eite two ale boler Ronden, near the section IIne betweon ecetlons 11 and 14, T. 3 N., R, 40 E. Of thl total capactty, about 100,000 A.T. would be in the recervolr above the 2,400-foot contour. Drilling nax at or nchr this eite" connection with F.P. Projeet 75I showe "broken Iave rock" to doph of 42 fent. Mron 42 to 62 feet the drill $10 \mathrm{~g}$ showe a "eloee, hard grained andeolte and frow 62 to 92 foet "broken law roek". Dr1ll1ng otopped at 92 foet, and 14 wa concluded that the ofte was not ouitable to concrete den. No geologie

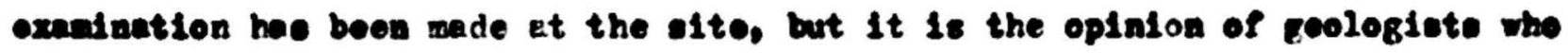
have noted the dr1II log thet it wey be oulted to an carthon or rock-P121 dan of broed base. Fith a cut-off all.

Backvater froe a 250-foot dan at the Sheep Creck olte could nood on

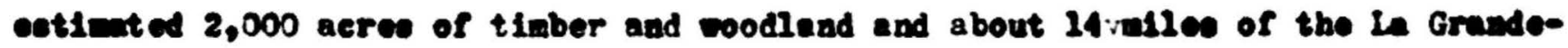
Joaph brench If of the Unton Paclfie Ry. Relocatlon of thie rallread would bo the prineiple itew in the aequieltion of right-of-gey for the reoervolr. The relocation of the rall roed would be to 1 te ovn advantage, however, co far as regarde grade. The $14-a l l e$ stroteh is wow located on an evorage grade of about 25 feet per alle. Reloeation could eliainate all grade in this reach 18 oultablo roed bed is found near the $2,500-800$ contour.

\section{Generel Plen of Dovelopment.}

A rough, prellainary study of the proposed Grande honde-Yalla Fella divorolos project ouggente the following general plan of developents an carther or rockIill dar at the Sheop Creek den elte on the Grande Ronde River In eectlon 11 and 14, T. 3 N., R. 40 E., 250 foet in holght above the water ourface, an

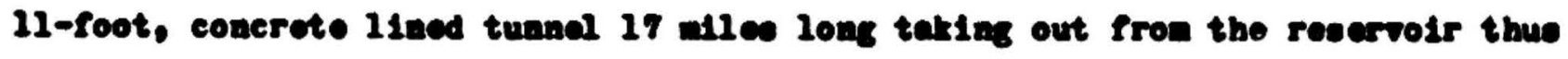
created at an elevation of 2,400 foct acar tho wouth of Lookingelace Great, in , See. 29, T. 3 N., F. 40 E., and diecharging 1 ate the South Fort Walle walle River 


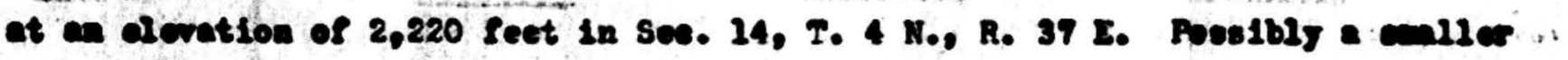

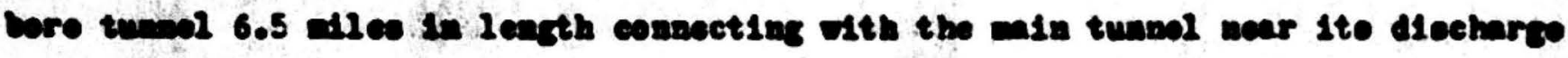

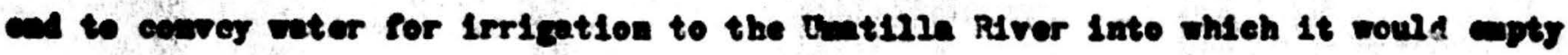
If se.. 27, T. 3 R., R. 37 E. This tunnel could be constructed on aplight crede

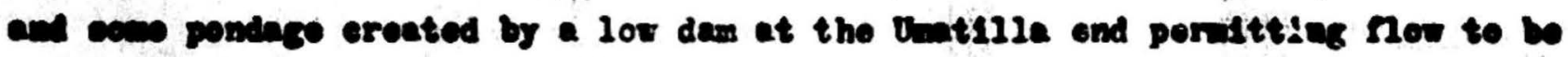

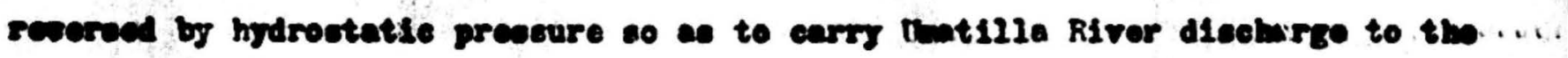

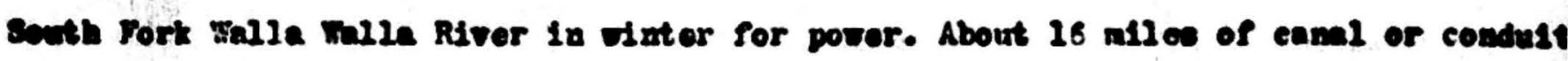

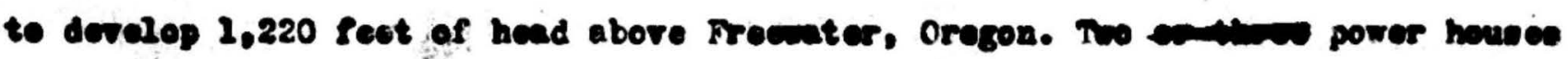
or the South Fork Wlle walla River with a totel inatslletion of $50,000 \mathrm{~K}$.,

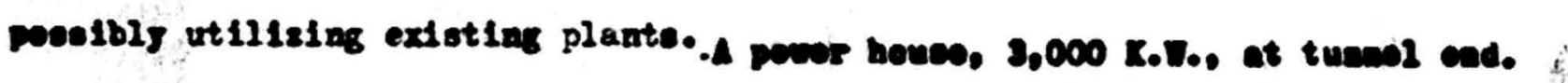
Thle ropgh prelfintary plen would be eubject to posalble mide adjentant after further otudy of the irriglble ares bolow Midton-Frecuater which my require the recorvation of wore head for irrigution cenle with a coscenuent 1000 of hend to peror.

On the bate of a 16-year record of diseharge for the Grande Roade Rifar. at Rondora (1926-48) it is eetimeted thet etorage of 100,000 acre foct above the

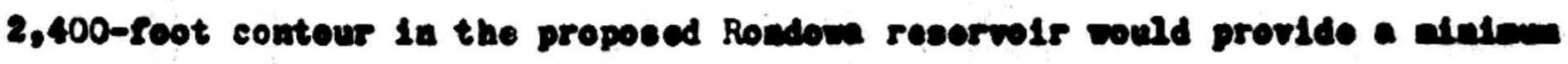

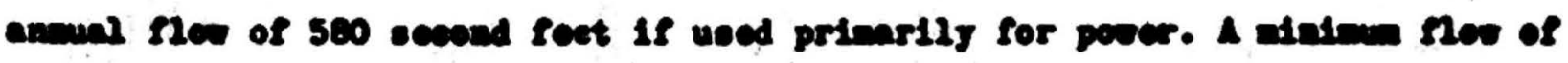

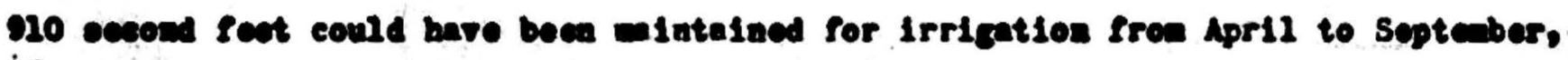
i.

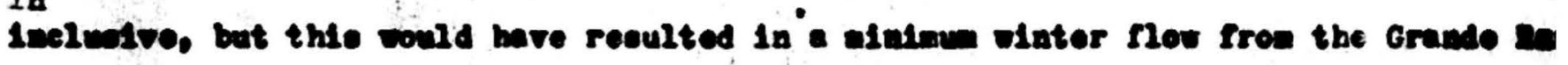

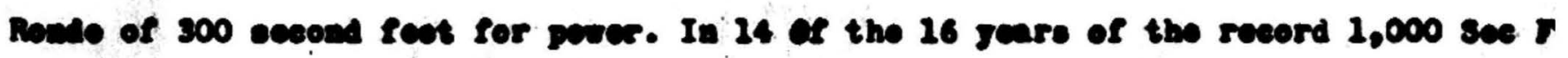

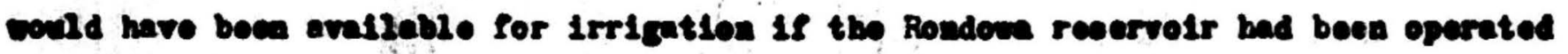
Sor Irrtention parpoces primally.

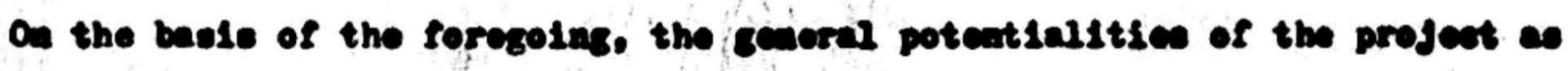

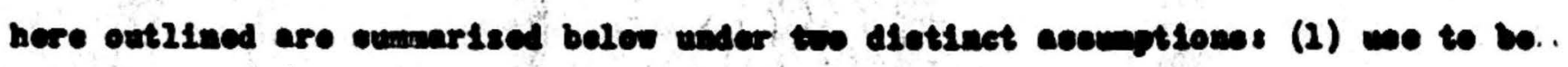

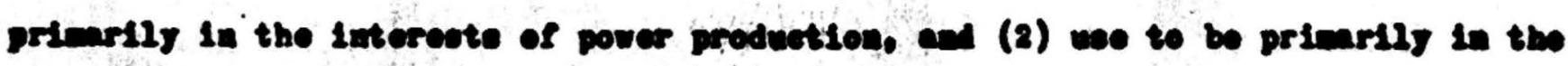
intercote of Irricatiod. 


\section{Plen I. Oparation for merer nelarilye}

If tw profeet wore operated primerily in the interesto of powor production, the I6-genr record of cdlecharce for the Grande howde at Rondens ladientes that a :

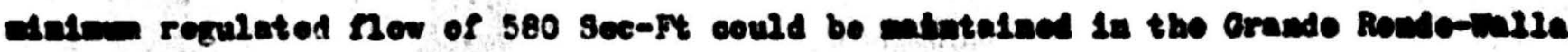

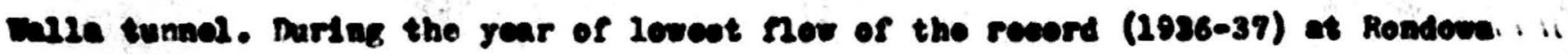

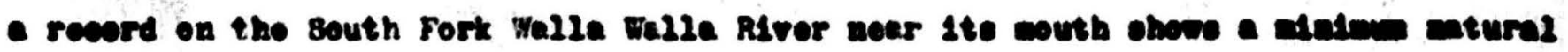

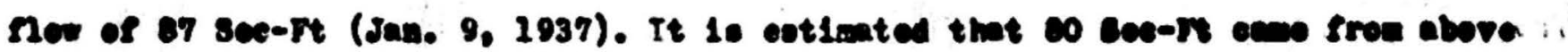
the proposed tunnel discherge end. Thle would make a total afnime 8100 of 660 sees

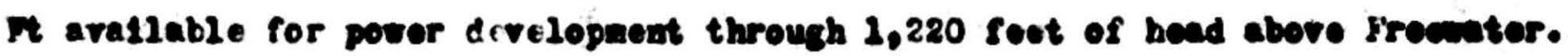
Wlth a Now of only 580 sec-Ft in the tunacl (diemeter, 11 Nt., elopo, .003) It

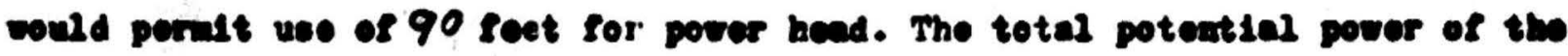
projoet undor conditione of now as above outlined is oumarlsed as follows

Potedt lal perer from Rondon Diverelon Prolent

\begin{tabular}{|c|c|c|c|c|}
\hline site & Head (rt) & M1n. $10=$ & H.P. & K.日. \\
\hline $\begin{array}{l}\text { Tanel } \\
\text { So. Fr., inale Varle }\end{array}$ & $\begin{array}{r}90 \\
1,220\end{array}$ & $\begin{array}{l}580 \\
660\end{array}$ & $\begin{array}{r}4,170 \\
64,400\end{array}$ & $\begin{array}{r}3,100 \\
48,000\end{array}$ \\
\hline
\end{tabular}

vader thle plan a minimen now of 660 see-rt vould have been avallable for

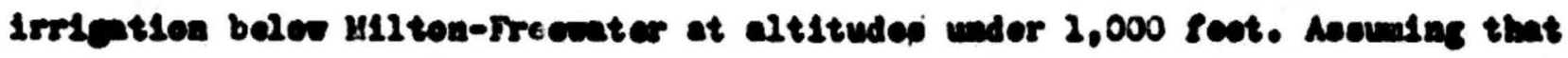
6 aere fact of mitor por acre dellvored at a unfforn rate of flow would ecet Irrigatios demale, the Now belor illton-Freemator would have oupplied 10,000 aere

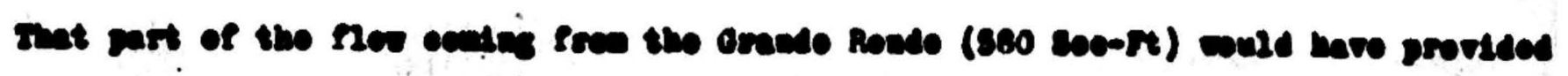

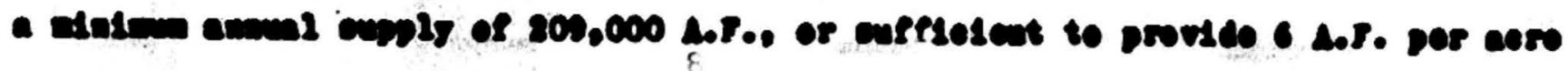

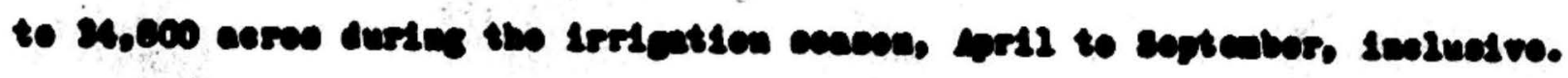




\section{Plan II. Operation for Irrigation primarily.}

If the profect wore operated prinarily for irrigution the proposod Rondowe revervolr would then bo used to doliver water on an irrigation deand echedule. In so far askthe capaeity of the tunnel would permit. A etwdy of the roeord at. Roadewa shows that a storage capcelty of 100,000 A.F. would have ade avalleble - aininum flow of 1,000 Sec-Ft for irrigation in all but tor yeare of the 16 jeare of the record. The exceptione ere 1931, when only 910 Sec-pt would have beon avald

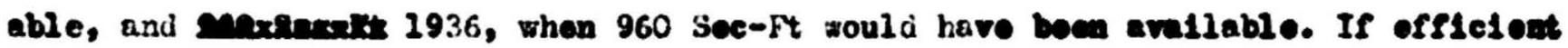
use of all evailatie flow could not bo made in the welle talle valley, a taneol

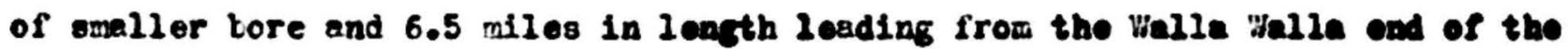
noin tunnel to the betilla River could bo constructed to doliver wator to tho "watilla valley for irrigation. It 1o roughly eatimated that a total aree of 60,000 scres In the Talle walle and bat1lla vallege could be 1rrigated froe the Grande Ronde diveraloa.

"nder this plan (end dioregarding any possible coatribution from the Unatilla kivero an eatimated sinimun flow of 400 sec-rit would be avallable for power developecat, of which about 200 see-it would be contributed by the South Fork Walle Talle River. This total Row could be developed through 1,220 foet of head above Freewgtor, and would generate 29,000 K.

If all vater were diverted to the Filla Jalla bagin a 050 Nlow of 910 sce-Ft would be avallable for power. Thic would ropresent $66,000 \mathrm{~K} .7$. for 50 poreant of the tine. 


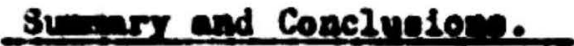

tho Grande Rosdo-llalla tulle divereion project, if deoigmed primarily for pewor, would require the following etructures:

1. Aa earthon or rockfill dan, 250 feet high, Vol., 6,000,000 Cu. Ydo.(earily)

2. A tuanol 17balles long, $11 \mathrm{ft}$. diamoter, slope, .002.

3. About 16 mllee of pover canal or condult.

4. A totel Inatallation of $51,000 \mathrm{~K}$. W. on South Fork valle Walla River.

Sened on 16-year record of diecharge for the Grande Ronde River at Roadowa, the project would develop 51,000 K.\%., and would supply an annual miatmen of 209,000 A. F. for irrigation, or In 14 of 16 years would eupply 240,000 A.F.

If developed primarily for irrigation the profoct would requlre a total Installation of $36,000 \mathrm{~K} . \%$. if 850 powor ehould be dereloped in full. It rould

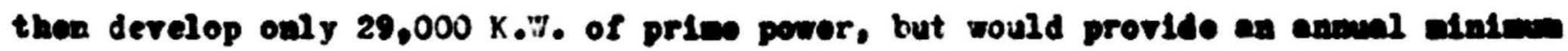
of 330,000 A.F. For Irrigation, and in 14 of 16 years would prov1de 360,000 A.F'.

If there ohould be a surplus of weter for use in the walla falle velleg for irrigation, a part could be diverted to the lnatilla velley, but this would add the cost of 6.5 miles of tunnol and vould lower the yield of G5O powcr.

Following is an eatimate of the value for powor and for Irrigation of the project under the altornative plane of operation:

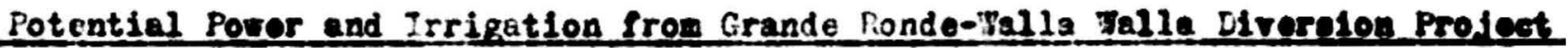
K1lowatte sere-feot avellable for Irrication April to Septemer, incluntive

\begin{tabular}{lllll}
\hline & 0100 & 050 & Y1nin & In 14 of 16 Ym \\
\hline P1ax I & 51,000 & 51,000 & 209,000 & 240,000 \\
PIan II & 29,000 & $56,000^{*}$ & 333,000 & 360,000 \\
\hline
\end{tabular}

Hosumes ell flow diverted to walla wella beala.

At $\$ 15.00$ per K.W.Yr. for prine power, and 1 mill por K.W.H. for dusp power, the potential returas from pever are eatineted as follow for the projoets 
$\frac{\text { Plon I }}{51.000 \mathrm{K.7.Yrs}: 555.00 \cdots \$ 765.000}$

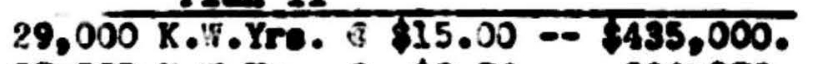

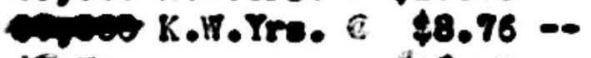
18,500
Plen II

42.19

Total yield

$$
\$ 765,000 \text {. }
$$

The estimated value of dusp (Q50) powor at 1 mili por K. avallablifty during the irrigetion seacen when it could bo used for puping. The

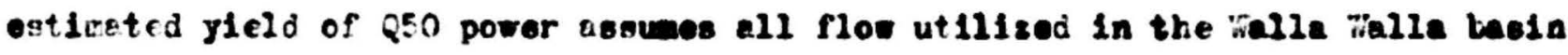
and consequently none direrted to the ventille besin.

Vinder Plen II a total insteallation of $66,000 \mathrm{K.T}$. would be necescary, but wo power house would be constructed at the tunnel end, since the tunnel would bo discharging to enpaetty for about alx wouthe of eech year, leaving wo head in the tunnel available for porer.

The lergor conduit necensary under Plan II to earry 850 flor would antall nose additional coot.

Construction of a 6itmile tunnel to carry vater to the rentill valley would ontail a meterial additional cost, but, if all nov wore utilized in the wallu Welle besin, this cost item could be eliminated.

If all flow could be utilized in the Falla Falla basin it io appareat that the more economical developnent and operation of the project vould be for Irrigetion prixarily. "Inder PIan II the total entinated revonue fron poser sould $62>2 \%$,

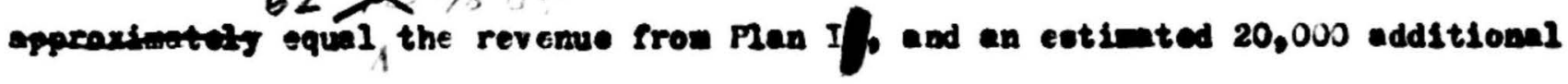

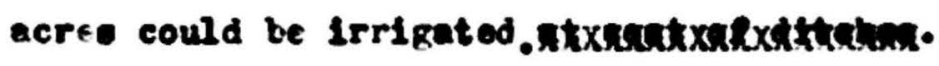

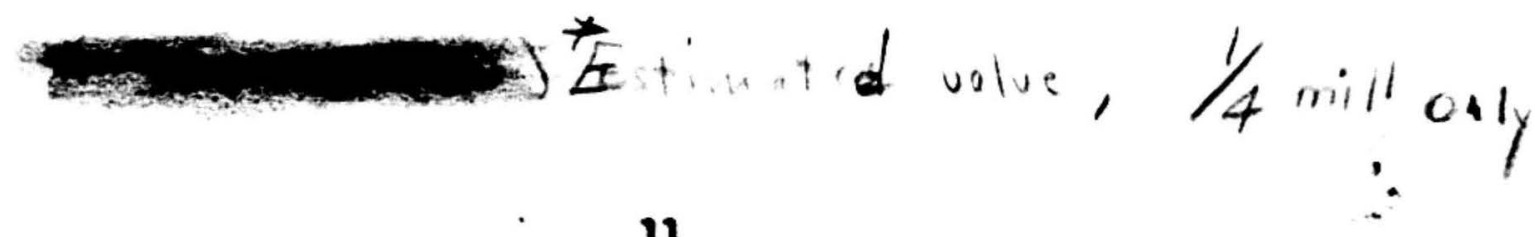

$\mathbf{1 1}$

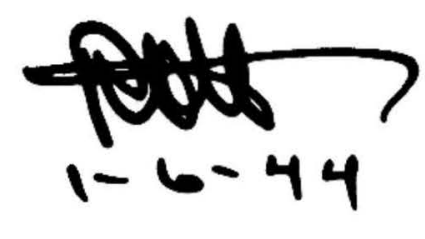


Following 1s an estimate of costs of the project; osouning thet it is deslgned for operation under Plan II, and that all flen is uod In the walla Walle baoin:

1. Sheep Creok dan, carthen, 6,000,000 cu yde $120,000,000$.

2. Land acquiteit1on, 2,000 acres o \$50 $100,000$.

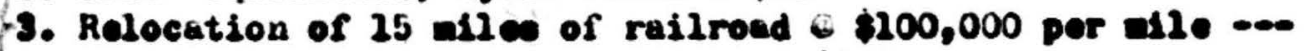

4. Tunnel excavation 435,000 cu yde $\$ 8.50$ $2,500,000.0 / K(3, p)$
$3,697,500$

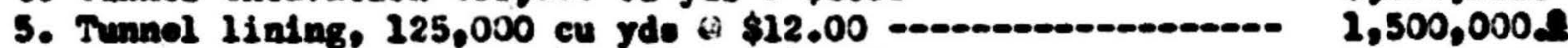

6 . 16 ailes of wood stave pipe $(10-f t) \& \$ 20$ per lineal ft $-2,2,700,000$.

7. Installation of $66,000 \mathrm{~K}$. त. (turblace and genoraters) \&\$20 1,320,000.

8. Aequisition of P.P.\& L. righte and structure (rough) -... 500,000 .

$$
\$ 20,317,500
$$

Some salvage of P. P. C L. structures would be possiblo. Aovining a total coet of $\$ 20,000,000$, an overall charge of 5 percent for interect, anortizet100 over a 50-year perlod, operation, mintenance and replacemente, and no tuxce. the retirement of the total debt in 50 jeare would require anneal paynute of $57 \% 000$ $\$ 1,000,000$. Deductiag from this total anmed an eotimeted $\$ 960000$ reeolved froe eale of power. a belance of fowpoo would be charged to irrigation. If 60,000 acres could be Irrigated from the Grande Ronde diversion, Irrigation coste 6.72

vould average \$hoo por acre per year over the 50-ycar period. This estinate does not, Include the coet of irrigation ditches.

$$
\text { R. 0. Hellund }
$$

Portlend, Ore. Jan. 6 . 1944.

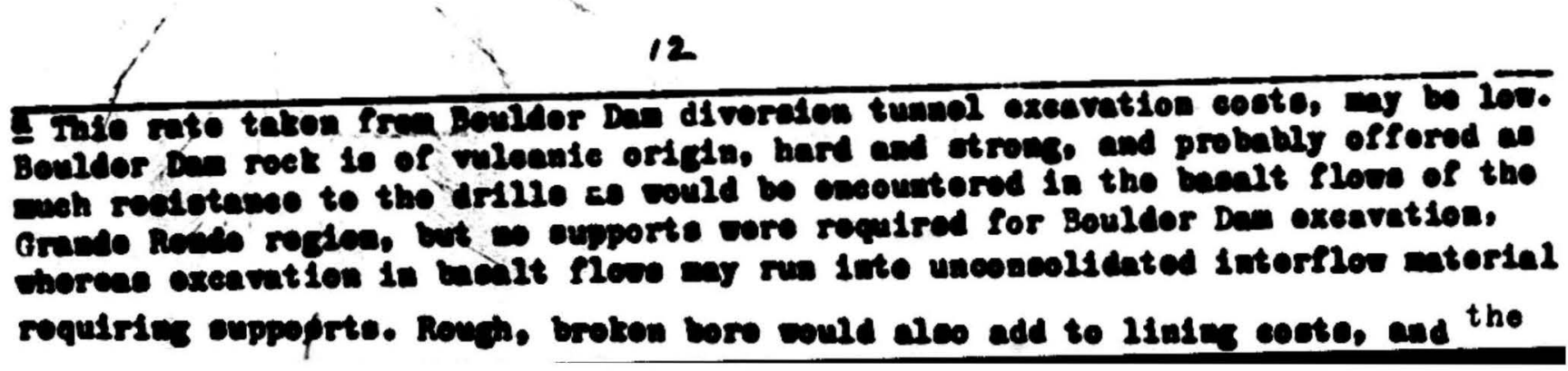


long haul increase mucking costs. The rate is used on the assumption that tunneline mothods are gaining from experience. 
Herinth is a brief report on the posibility of diverting the Grande Roade River into Walle Walla and betilla Rivor drainage for power and irrigetion, oubaitted in eccordance with your mecrandu of Deceaber 1, 1943.

Tn the aboence of adequate field information it has been acceosary to make a large maber of assumption. The ostinated capaeity of the Shen Greok (Rondowa) revorvolr wte is beed on the Hellowa River ourves and a rall road profile thoving the Union Puelfte brameh lino running along tho Grande Roade bove Rondowa. I think the estialed capacity Is consorvative.

The meximum delivery of water by tunnel would permit of rery 1stelo

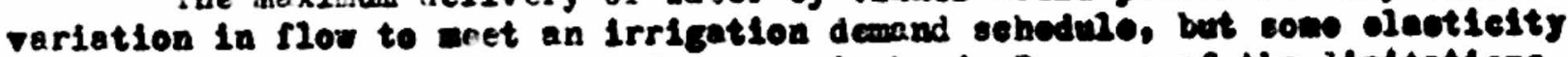
would be poseible through use of reservolr head. Beceuse of the Initatione inposed by tumel eapecity I have dealt in second feet rether than In aero feet in discussing 1rrigation.

In eatinating coste I have borrowed frow "Dono and Control vorto" by the Burcau of Reclention, frow U.S.E.D caglneore, and fron hrione ecettered sources. Financing is based roughly on preeent ".S.T.D. methode, aserding an

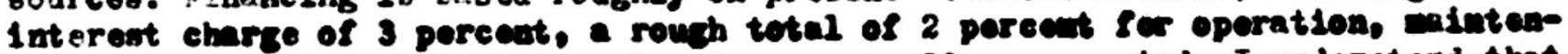
ance and replecemente, and smortisution over a 50-year poried. I uaderetand that

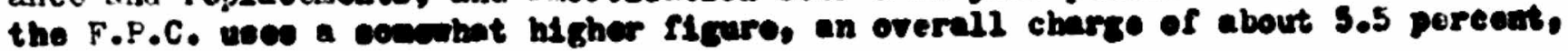
plus operation coets.

Although costs huve in general been estinated on the bavil of pro-var prices and neges, and would be auch greater on the backs of currest values, It

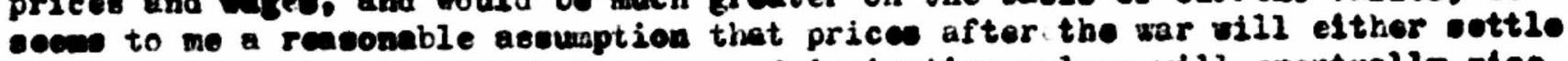
back to former levele, or that powor and irrigetion values will eventually rieo to belence the rise in other comoditice and in labor coste.

The principle item of coot, $\$ 10,000,000$ for the earthen den, is eubject to wide adjuotment after complete information 15 evallable. The volue io baced on a $1: 4$ upetren and a $1: 3$ downtrean slopo, and aveuce that suitable earth can be found nearby. Suitable borros pite could posnibly be located on top of the platean. Spliliry cost is iusped in the total. The coet as I have estimated 1t, io a rough everage taken from eovertil of the largo carthen deme bullt by the Pureau of Reclenation. It 1e appareat that a great deal depeade on the haul in computing cost of earth fill. Pield examination might reveul songthing in this regard, but ohould probably be ade by en enginecr with exporience in this 1 ine.

It io eppareat that the proposed diveroion project could follow one of ecveral plane. I do not consider that this roport deals ofth wore than one of

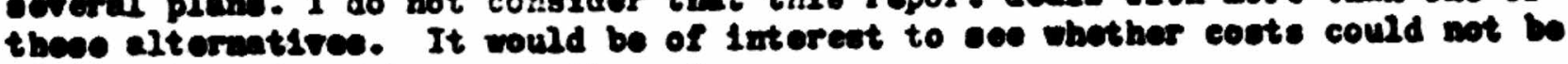
nterially reduced by come other plen.

I belleve that the potentialition of the projeet justify furthor otudy and that all pablic lande alows the lise of alternative tunnol location obould be clesalfied a pover sites. 


\section{$x \times x \times x \times x \times x \times x x x$}

222 O1d Court Howee (U.8.)

Portlasd, Ore. Jas. 10, INA

MTORMNDU sor Ne.

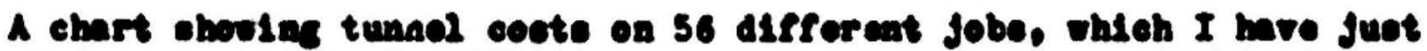
reoolved free Ir. Dobler'e offlee, arrived too late to bo avalleble for $a$

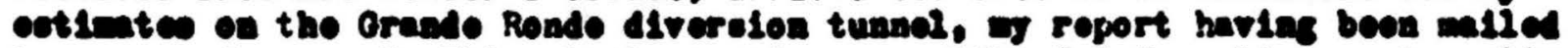

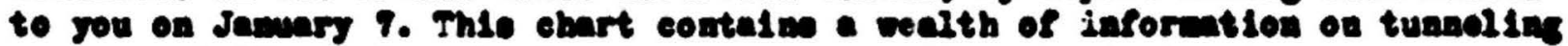
coete, and If you do not alrcady have a copy, you ney deolre to roquent one 4

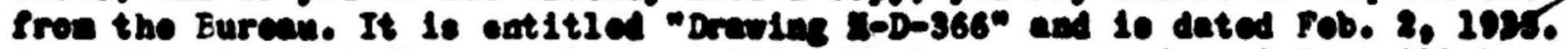

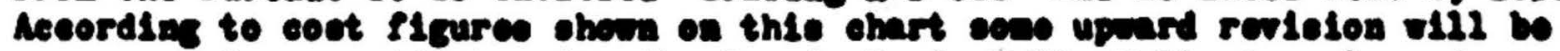

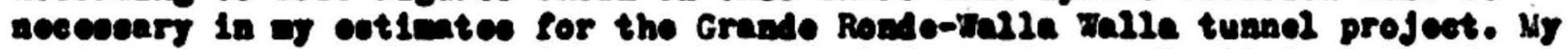

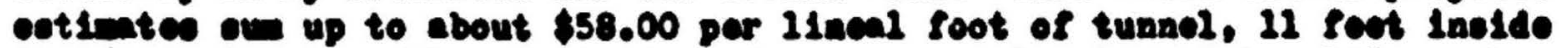
Piniohed diencter. The chart ohowe 3 bhort tunnole through bacaltse rock, and

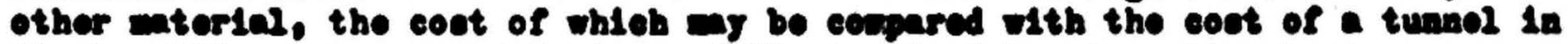

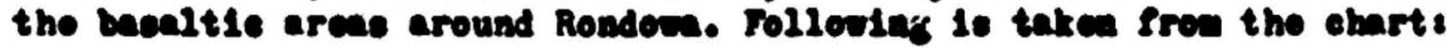

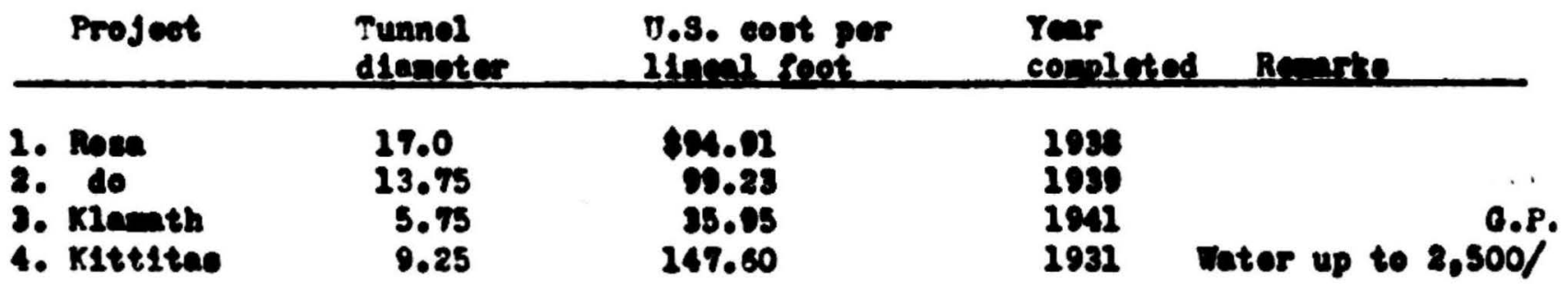

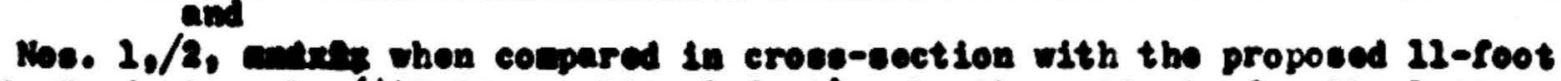
Grande Ronde tunaol, (\$58.00 por lincel soot) sake the cot inte for the lettor

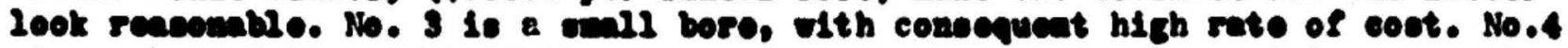

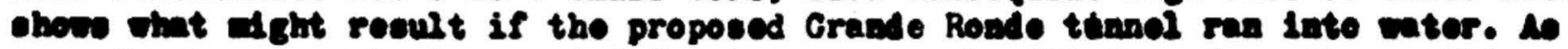
grousd enter experto have polinted out to we much w111 dopend on tho position of the ground water tablo. Tunnoliag frem the discharge end would perilt cany dralmge of ang enter that alght be encount ored, but tunnollas froe the uppor or Intake and would 1wrolve a corlous drainage problen that alght make tho whole projeet Inpractleable. Thlo would rcoult free the great 20 ath, 17 milee.

The chart doce not deceribe any tunnol of wore than and a fraction alles 10 Ieacth. 10 topography 10 avallable from which to doterniso tho poeclblesty of elnilins obnerte at Intorvale for tho Grande Rosde tunnol project, and 1to creat Ienjth would probebly wake oweh ehafte nocecesary. Tho flrot nood for a

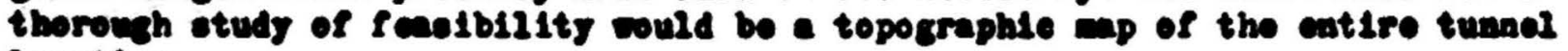
locat1on.

If the calarice and othor offlee expeasen of covorinomet englacore ohould bo Ineluded In cotinteo of coot, a perecutage overhead charge mut bo added to $y$ cotintec. Apparoatly tunnoliss ceoto mut carry aleo a chares of

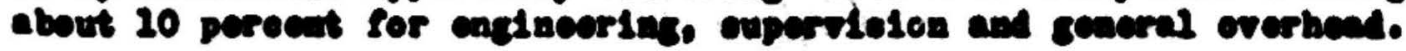


228 ore court House, (U.8.) Portiand, Ore. Fob, 1, 1046.

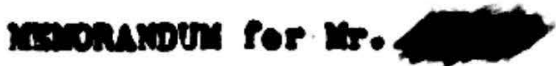

Thth furthor roforome to as brief roport on the poeslble orande Rocdo-inlle Elle disorolose

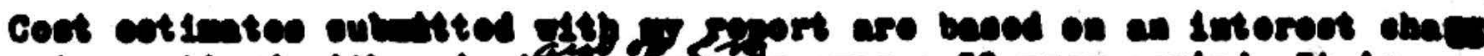

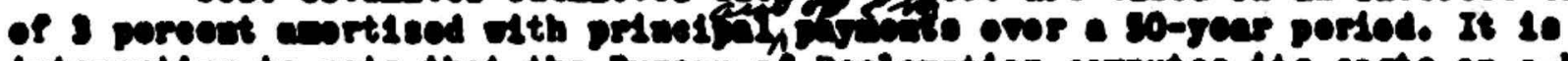

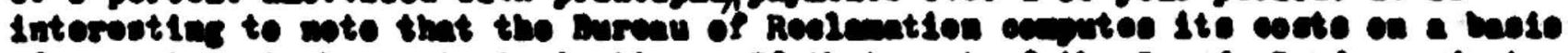

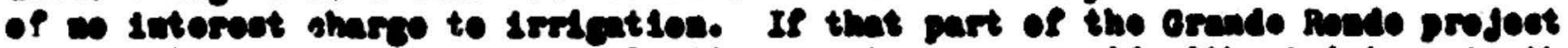

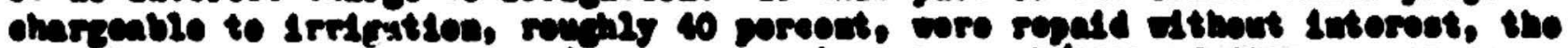

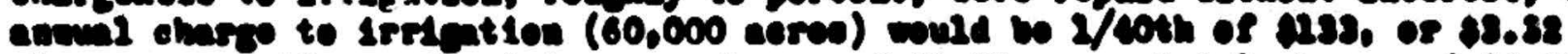

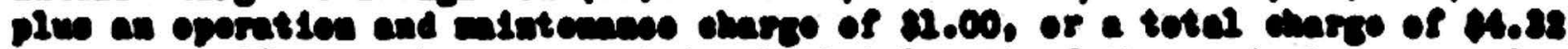

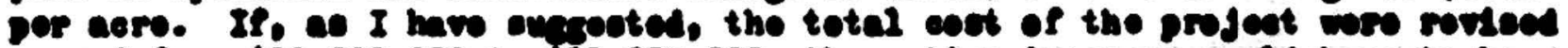

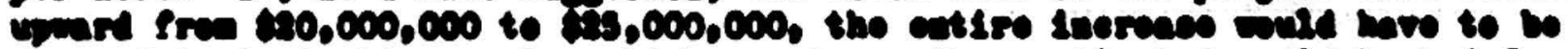

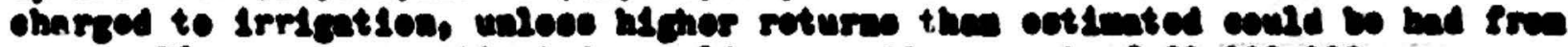

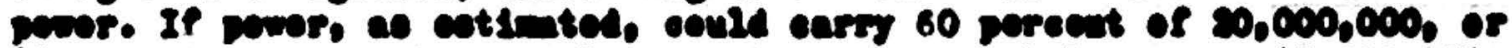

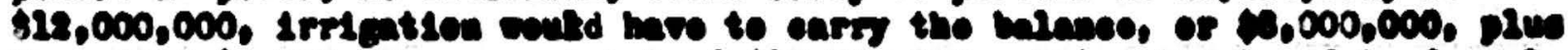

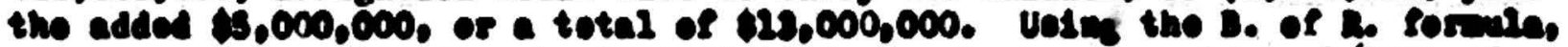

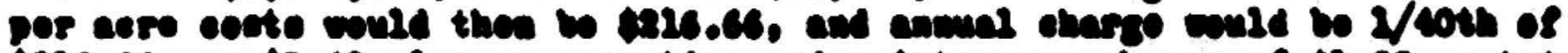

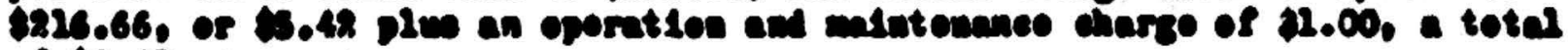
of *3.48 ver acro.

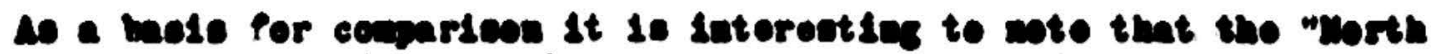

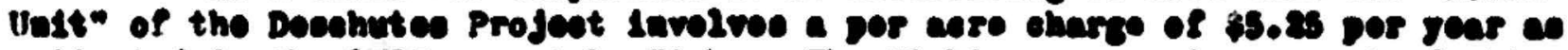

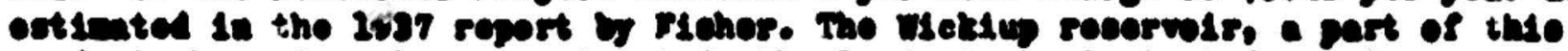

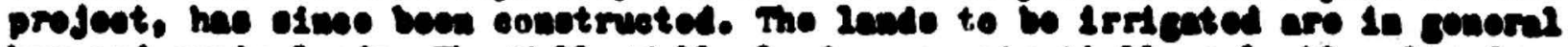

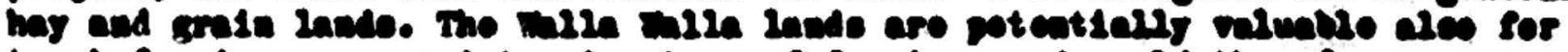

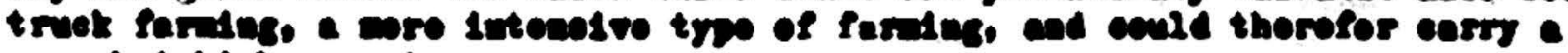
eccomiant idphor ecot.

Anothor feotor that could affect tho fcacdulsty of tho project 10 tho

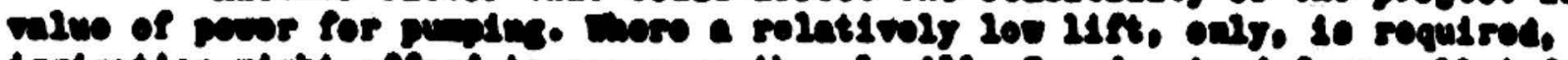

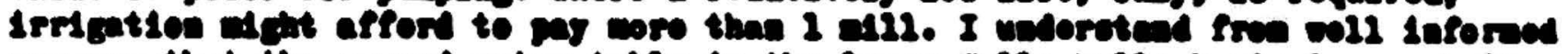

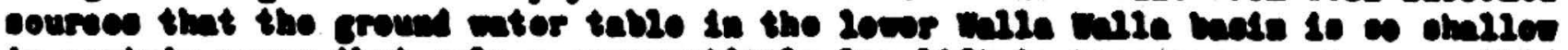

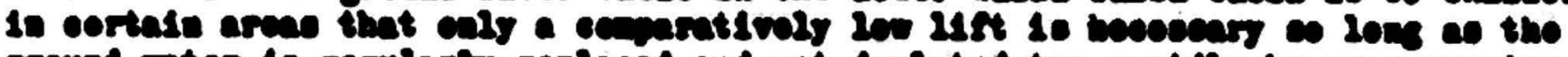

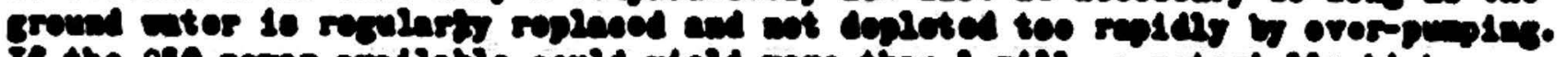

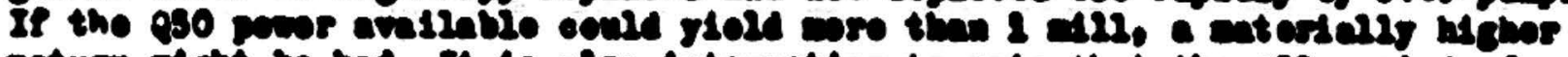

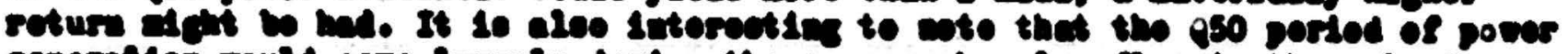

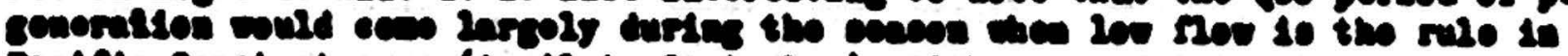

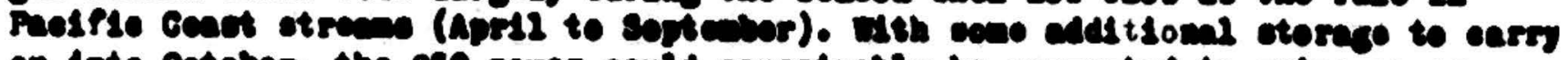

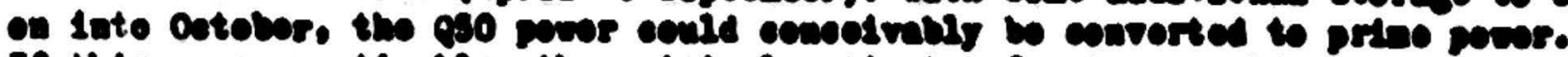

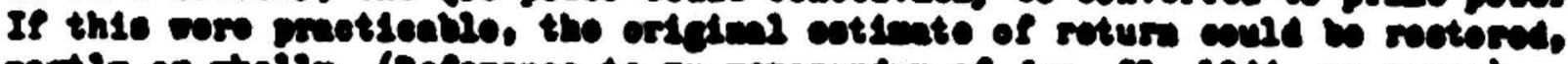

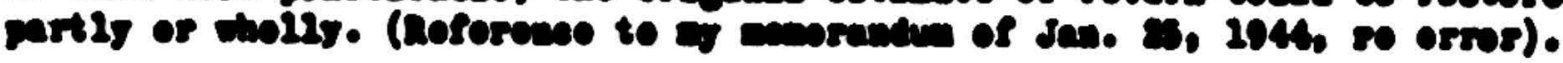

Vory truly reure.

R. O. HoL2end 


\section{Grande Ponde}

\section{UNITED STATES \\ DEPARTMENT OF THE INTERIOR \\ BUREAU OF RECLAMATION}

P. 0. Box 499

Grants Pass, Oregon

lisech 3,1945

Hr. Randolph 0 . Helland, Hydraulic Engineer

Geological Survey

212 Old Court House (U.S.)

Portland, orezon

Doar Lir. Helland:

Your letter of December 26 to kr. C. C. Fisher at Salem regarding the Grande Ronde Project was forwarded to this office for reply. In some manner the letter was misplaced before the requested data were worked up. I am very sorry that the reply was delayed for such a lons time.

No information is uvalable in this office on the Wallova River above Wallowe. I am uncertain as to where these data could be secured. Possibly the Boise Office may have some information with regard to the Wallowa kiver.

With regard to the Grande Ronde River above Elgin, the following data are subritted in response to your request.

(a) The potential Grande Ronde Project developnent would consist of three units: LaGrande, Union and Cove, for which the principal source of supply would respectively be the Grande Ronde River, Catinerine Creek, and Indian Creek. The following storage reservoirs would serve the units:

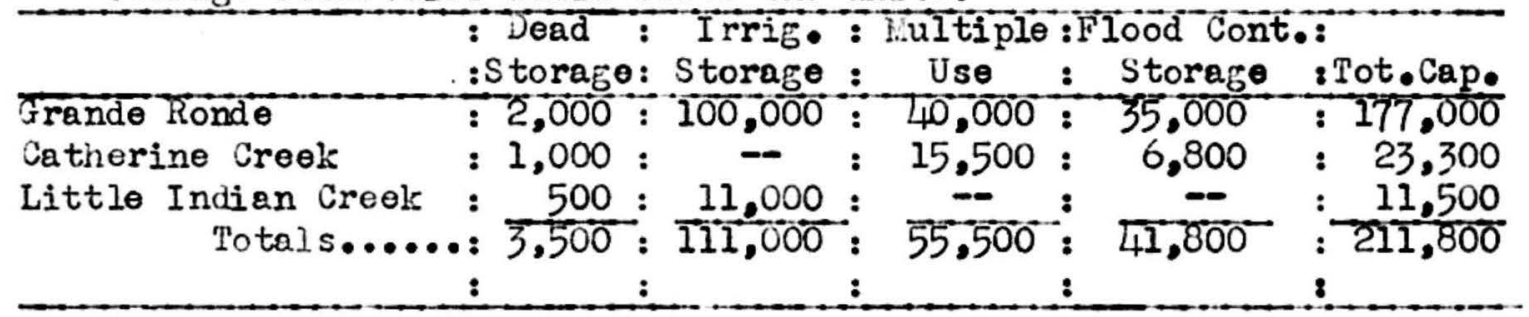

(b) About 26,400 acres of land are now irrigated to some extent within the project area. The distribution of these lands and an estimate of the stream depletion by them is as follows:

Present Irrigation Development

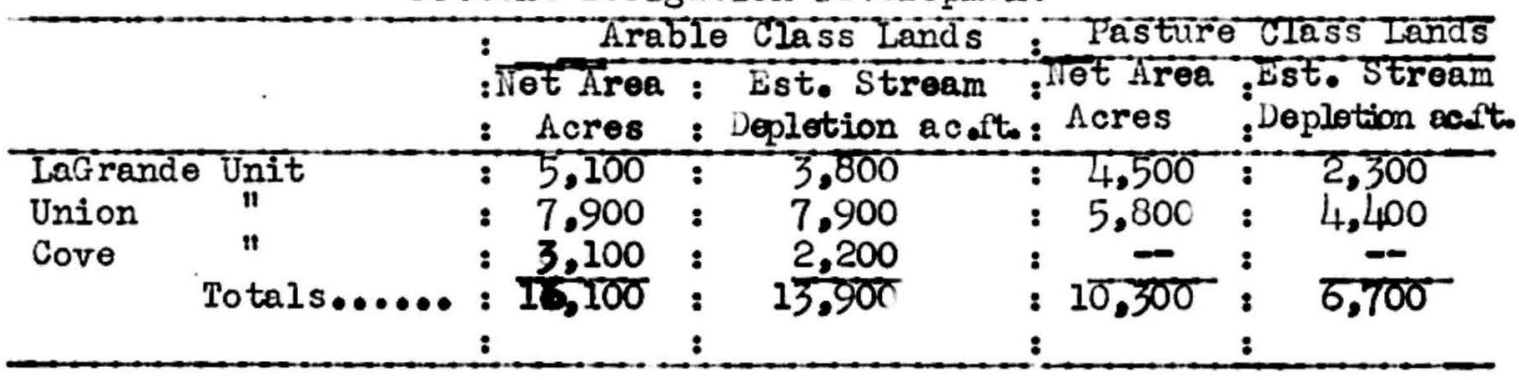


(c) When fully developed, the project will furnish a full water supply to 63.500 acres of a rable class land and surplus and return flow to 32,900 acres of pasture class land. The acreage distribution and estimated stream depletion under ultimate developmont are as follows:

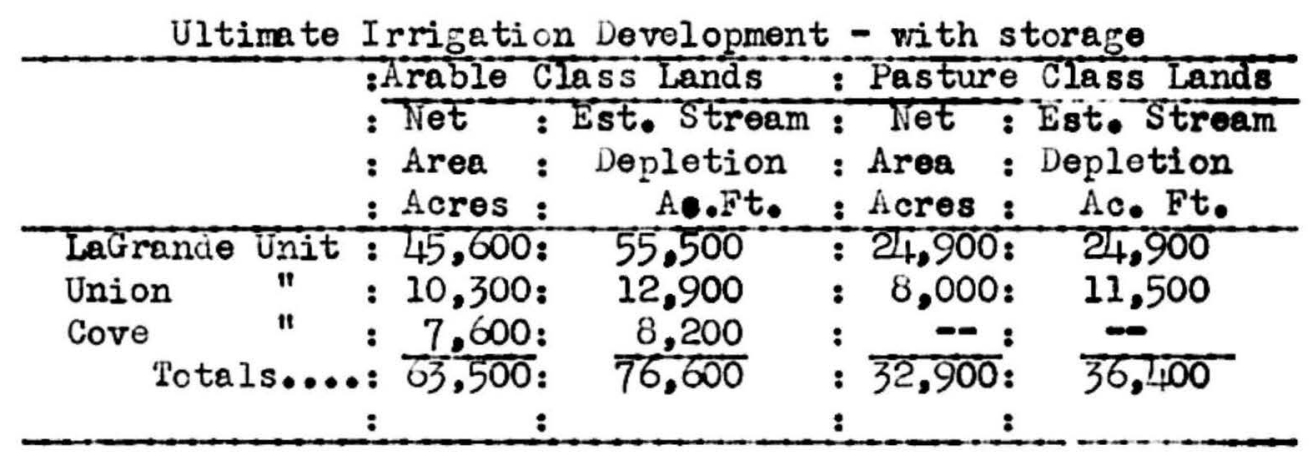

(d) For the ultimate development the stream diversion requirements for the lands are estimated to be as follows:

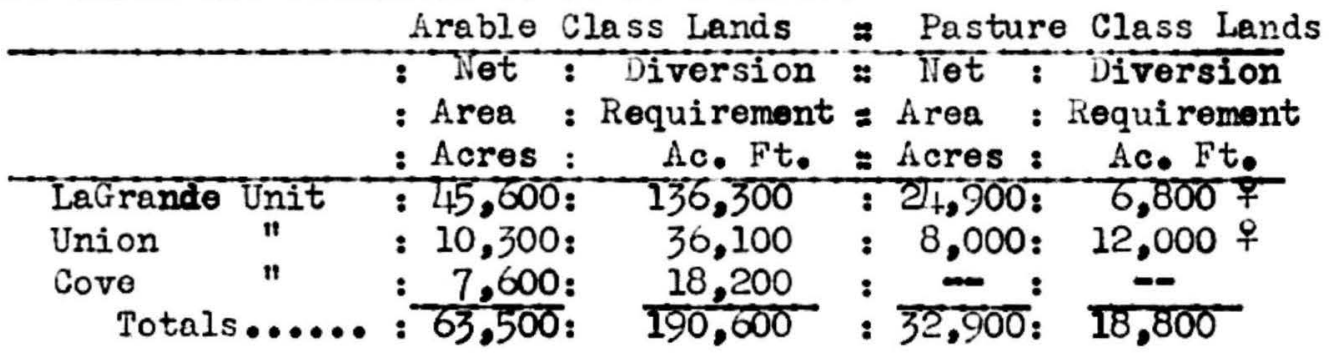

우 Requirement for pesture class lands with prior rights which must be supplied. Diversion for additional pasture class lands vill be dependent upon amount of surplus run-off and return flow avilable.

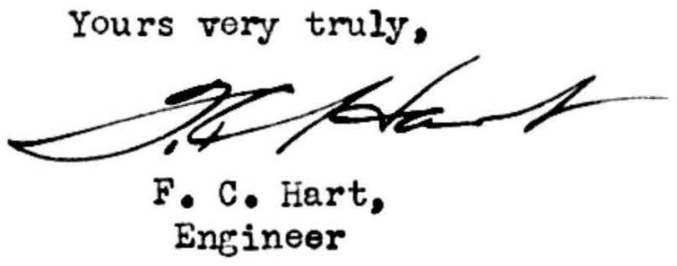

C.C. - C. C. Fisher, Engineer

460 liorth High Street, Salem, Oregon 


\section{A Briof Sumbry of Peots Dalating to the Poodbility of Divorting}

the Grande Roade RIver Into tho Fila Falle RIver for

Pover and Irrigation.

Ne an eltorwative plan for the development of pewer in the Grande Roude RIver bolos Rosdon, and a a couree of eupplementary Eator for Irrication in the walle welle relleg, and poesibly aleo in the Onatille River valley, tho poselbility of diverting the Grande Rosde mear Rosdone eppense to here ouffielont norit to Juotify furthor Inveotigat10a. By conotrueting a das 250 foot hich at the sheop Creok das eite two ailes bolor Rondow, en cotilated etorege eapaefty. of about 150,000 aere foet would be erented. A cenerete 11ned tunad, 11 foet in

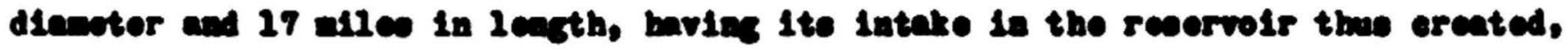
would earry the new of the Grande Rowde to a polnt on tho thing Fort of tho walle walle River in soe 14, T. 4. Mo, R. 37 B., beler whieh lt could be wtillzed through about 1,220 foet of head bofore its divoralon to irrigation canele. In the sollowing pages the profeet lo dicowence brieny as to avallable vetor oupply, poselbilitice for storage, goneral plem, and value for peser and for 1rrifation.

\section{Deter supely.}

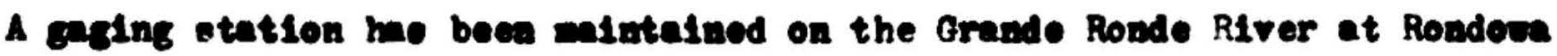
elnee 1926 about 200 foet beles the wouth of the wallow RAver, and about two

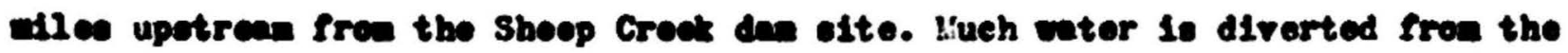
Grande Rowde at pointe upetrcen fron the gaging otation. The reeord indieateo In gemeral a heary runcoff fron Fobruary to Juno, wth a mold doelleo durlag ounere after wheh the river raniso 100 throughout the fall and water. A oumenry of this discharge rocord followe. 


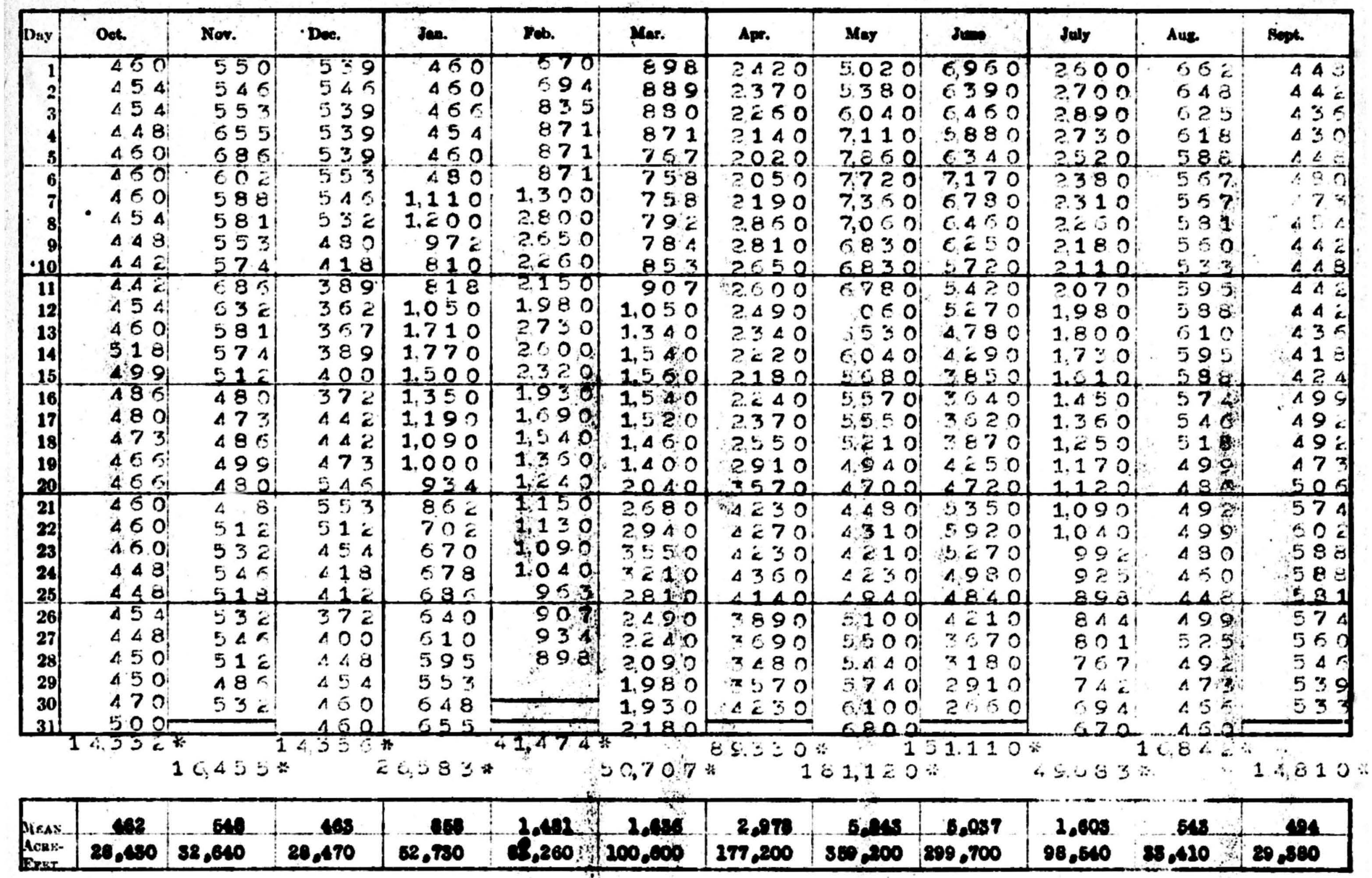




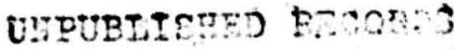

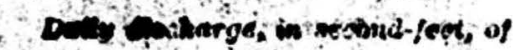

Galterite Greek na:ir. Union, Oreg.

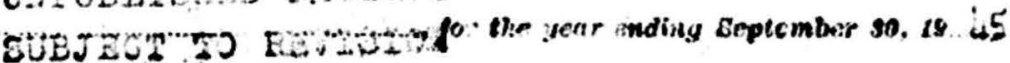

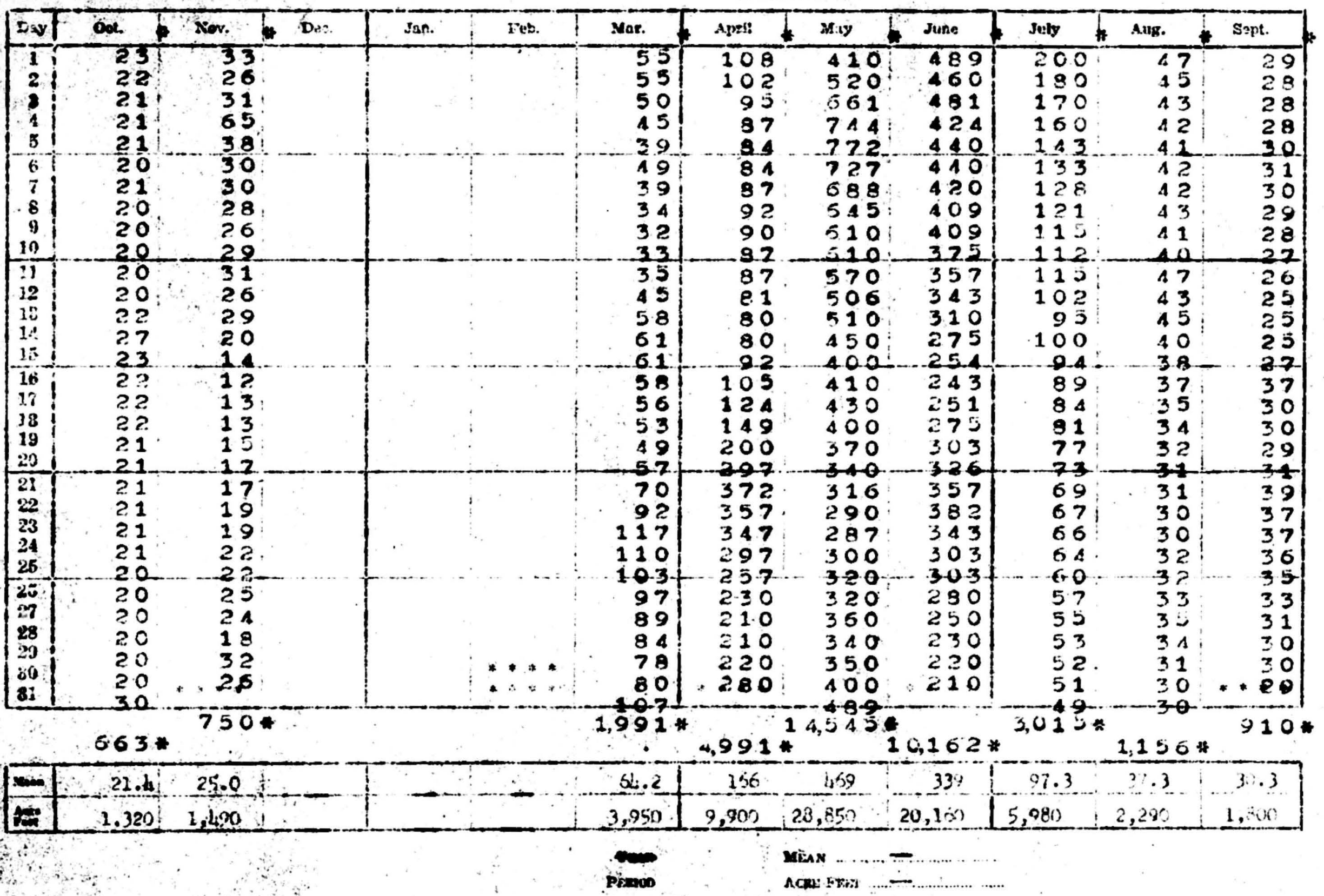




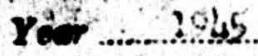

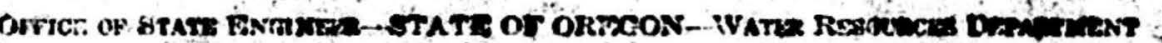

Hilvinber ....2816.

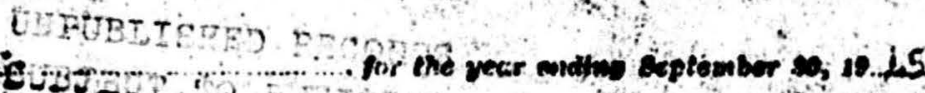

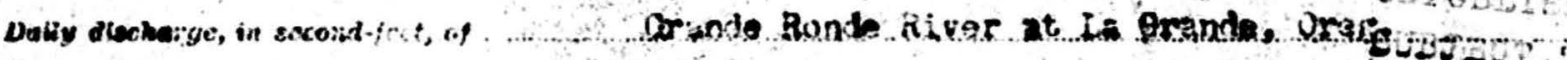

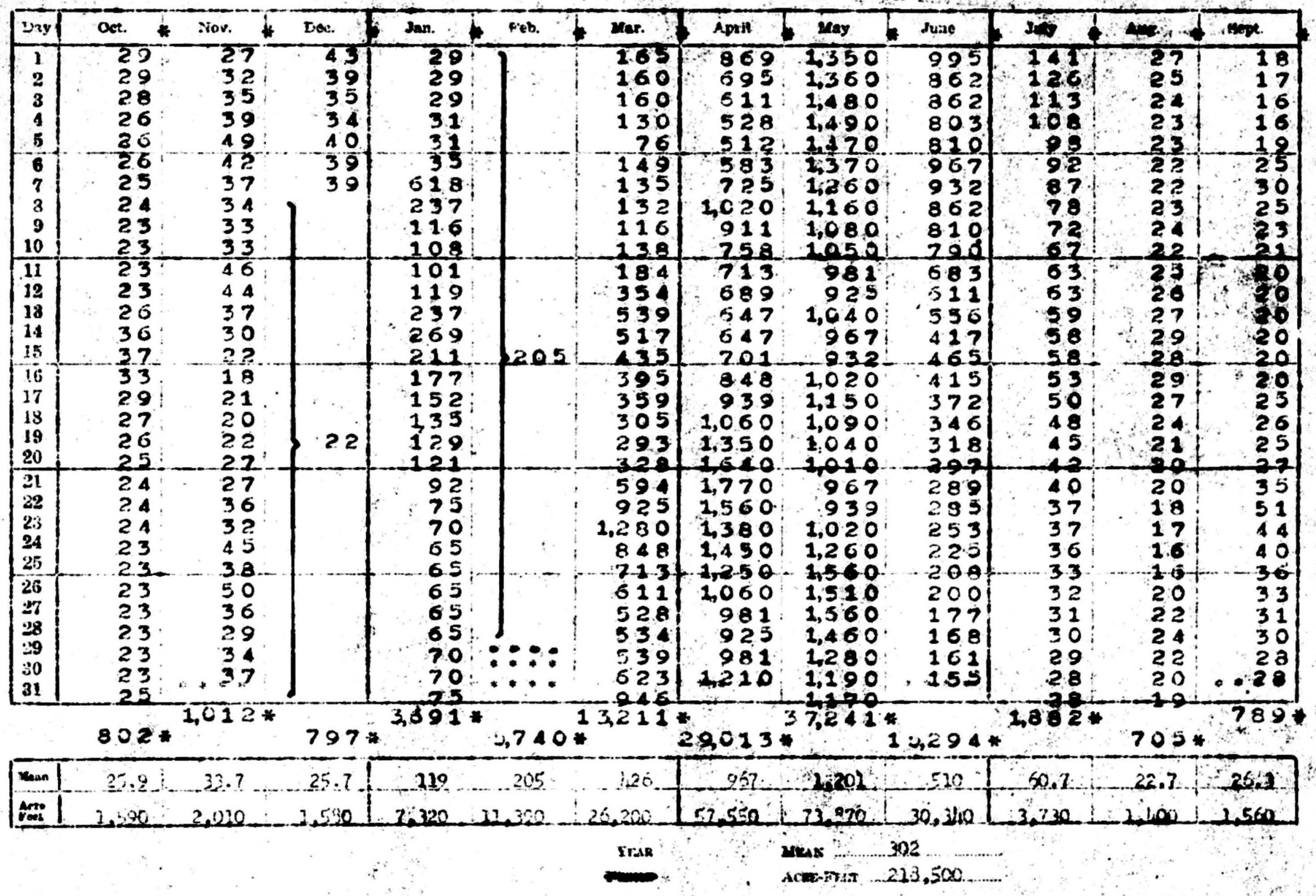


CNDUBIISEED P.SO

Filo Na

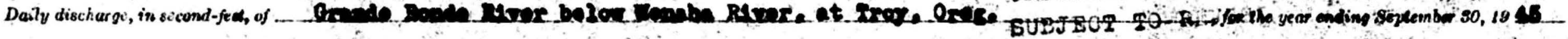

\begin{tabular}{|c|c|c|c|c|c|c|c|c|c|c|c|c|}
\hline Dry & Oet. & Nov. & Doe. & Jan. & Pob. & Mar. & Apr. & May & Juno & July & Aug. & Sept. \\
\hline \begin{tabular}{l|}
1 \\
2 \\
3 \\
4 \\
5
\end{tabular} & $\begin{array}{ccc}6 & 5 & 3 \\
6 & 0 & 5 \\
6 & 0 & 5 \\
5 & 8 & 1 \\
5 & 9 & c\end{array}$ & $\begin{array}{lll}7 & 1 & 5 \\
7 & 7 & 1 \\
7 & 3 & 9 \\
7 & 9 & 5 \\
E & 8 & 0\end{array}$ & $\mid \begin{array}{l}731 \\
731 \\
591 \\
547 \\
731\end{array}$ & $\begin{array}{l}633 \\
533 \\
633 \\
533 \\
533\end{array}$ & \begin{tabular}{rrr|}
9 & 0 & 0 \\
9 & 4 & 0 \\
1.1 & 1 & 0 \\
1.1 & 9 & 0 \\
1.1 & 2 & 0
\end{tabular} & $\begin{array}{llll}1.1 & 5 & 0 \\
1,1 & 8 & 0 \\
1.1 & 6 & 0 \\
1.1 & 5 & 0 \\
1.0 & 5 & 0\end{array}$ & $\begin{array}{r}3660 \\
3520 \\
3160 \\
3090 \\
2950\end{array}$ & $\begin{array}{r}7,130 \\
7,50 \\
8,510 \\
9360 \\
10100\end{array}$ & 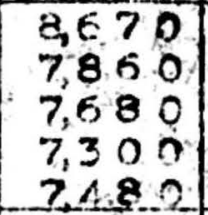 & $\begin{array}{l}3380 \\
3.280 \\
420 \\
3280 \\
3920\end{array}$ & $\begin{array}{l}796 \\
750 \\
720 \\
720 \\
733\end{array}$ & $\begin{array}{l}625 \\
619 \\
609 \\
622 \\
635\end{array}$ \\
\hline $\begin{array}{r}6 \\
7 \\
8 \\
9 \\
10\end{array}$ & $\begin{array}{lll}5 & 9 & 3 \\
5 & 5 & 3 \\
5 & 5 & 7 \\
5 & 0 & 3 \\
5 & 8 & 1\end{array}$ & $\begin{array}{lll}7 & 7 & 1 \\
7 & 3 & 9 \\
7 & 3 & 9 \\
7 & 2 & 3 \\
7 & 0 & 2\end{array}$ & $\begin{array}{l}731 \\
781 \\
747 \\
691 \\
505\end{array}$ & 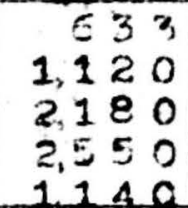 & $\begin{array}{llll}1 & 1 & 8 & 0 \\
1, & 3 & 2 & 0 \\
0 & 2 & 7 & 0 \\
4 & 4 & 1 & 0 \\
3 & 0 & 6 & 0\end{array}$ & $\begin{array}{l}1.030 \\
10=0 \\
1040 \\
10 \approx 0 \\
107\end{array}$ & $\begin{array}{l}2930 \\
3220 \\
5000 \\
4690 \\
1100\end{array}$ & $\begin{array}{llll}9, & 3 & 0 \\
9,1 & 9 & 0 \\
9,0 & 0 & 0 \\
8 & 6 & 1 & 0 \\
8 & 1 & 0\end{array}$ & $\begin{array}{llll}3,3 & 5 & 0 \\
8,6 & 1 & 0 \\
3,1 & 4 & 0 \\
7,4 & 8 & 0 \\
6 & 6 & 9 & 0\end{array}$ & 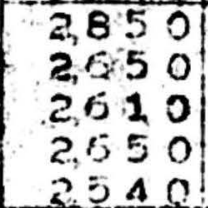 & $\begin{array}{lll}7 & 2 & 0 \\
7 & 3 & 5 \\
7 & 3 & 5 \\
7 & 4 & 8 \\
7 & 4 & 4\end{array}$ & 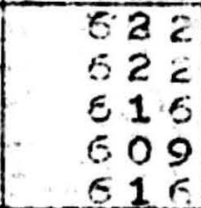 \\
\hline $\begin{array}{l}11 \\
12 \\
13 \\
14 \\
15\end{array}$ & $\begin{array}{lll}5 & 9 & 3 \\
5 & 9 & 9 \\
5 & 9 & 9 \\
5 & 1 & 4 \\
6 & 7\end{array}$ & 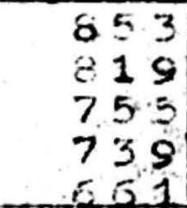 & $\begin{array}{l}518 \\
557 \\
557 \\
581 \\
533\end{array}$ & $\begin{array}{l}1.160 \\
1.410 \\
3090 \\
4090 \\
3090\end{array}$ & $\begin{array}{l}3180 \\
301 \\
340 \\
3700 \\
330\end{array}$ & 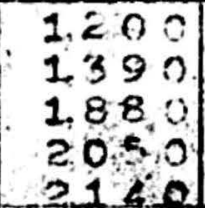 & 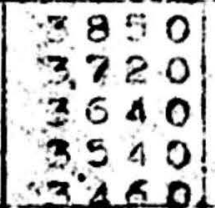 & $\begin{array}{l}8,800 \\
7,860 \\
8,800 \\
81.40 \\
7,50\end{array}$ & $\begin{array}{l}5380 \\
6190 \\
5840 \\
6230 \\
6590\end{array}$ & 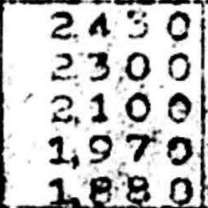 & $\begin{array}{l}750 \\
750 \\
780 \\
780 \\
76\end{array}$ & $\begin{array}{l}616 \\
622 \\
609 \\
615 \\
628\end{array}$ \\
\hline $\begin{array}{l}16 \\
17 \\
18 \\
19 \\
20\end{array}$ & $\begin{array}{lll}5 & 5 & 3 \\
6 & 2 & 5 \\
5 & 1 & 2 \\
5 & 0 & 5 \\
6 & 0 & 2\end{array}$ & $\begin{array}{lll}6 & 1 & 9 \\
6 & 1 & 9 \\
6 & 1 & 9 \\
5 & 9 & 1 \\
3 & 3 & 3\end{array}$ & $\begin{array}{r}691 \\
787 \\
747 \\
747 \\
84 .\end{array}$ & $\begin{array}{l}2,660 \\
2,280 \\
2,000 \\
1,740 \\
1,560\end{array}$ & 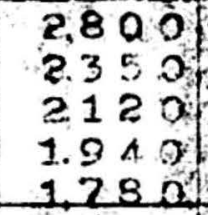 & $\begin{array}{l}2.140 \\
2140 \\
2080 \\
2000 \\
2780\end{array}$ & $\begin{array}{l}3460 \\
3660 \\
3870 \\
4500 \\
5330\end{array}$ & $\begin{array}{r}7,360 \\
7,350 \\
6,140 \\
6380 \\
6500\end{array}$ & 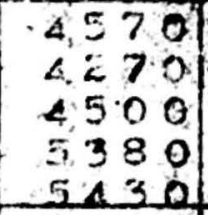 & 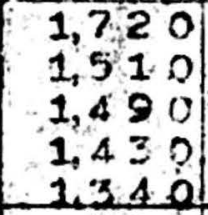 & $\begin{array}{r}750 \\
7 \% 5 \\
705 \\
577 \\
645 \\
\end{array}$ & $\begin{array}{l}663 \\
672 \\
674 \\
735\end{array}$ \\
\hline $\begin{array}{l}21 \\
22 \\
23 \\
24 \\
25 \\
\end{array}$ & $\begin{array}{lll}6 & 0 & 5 \\
5 & 0 & 5 \\
5 & 5 & 3 \\
5 & 9 & 3 \\
5 & 0 & 2\end{array}$ & 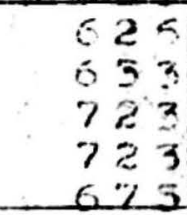 & $\begin{array}{l}827 \\
819 \\
747 \\
561 \\
647 \\
\end{array}$ & $\begin{array}{r}1.420 \\
1,330 \\
1,000 \\
970 \\
950\end{array}$ & 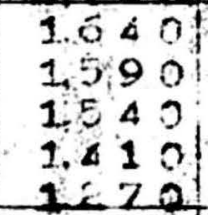 & $\begin{array}{l}4570 \\
4570 \\
5030 \\
4810 \\
430\end{array}$ & $\begin{array}{rrrr}6.8 & 2 & 0 \\
6 & 5 & 7 & 0 \\
6.2 & 7 & 0 \\
6.4 & 9 & 0 \\
6 & 8 & 4\end{array}$ & $\begin{array}{l}5900 \\
5870 \\
5050 \\
5550 \\
6550\end{array}$ & $\begin{array}{llll}5 & 8 & 4 & 0 \\
6 & 8 & 8 & 0 \\
6 & 3 & 2 & 0 \\
6 & 0 & 3 & 0 \\
5 & 6 & 1 & 0\end{array}$ & $\begin{array}{llll}1.2 & 5 & 0 \\
1,1 & 4 & 0 \\
1,1 & 5 & 0 \\
1,1 & 2 & 0 \\
1 & 0 & 3 & 0\end{array}$ & $\begin{array}{l}635 \\
63.5 \\
649 \\
649 \\
635\end{array}$ & $\begin{array}{l}758 \\
780 \\
776 \\
780 \\
765\end{array}$ \\
\hline $\begin{array}{l}28 \\
27 \\
28 \\
29 \\
30\end{array}$ & $\begin{array}{lll}5 & 9 & 7 \\
5 & 9 & 7 \\
5 & 9 & 3 \\
5 & 9 & 3 \\
5 & 9 & 3\end{array}$ & $\begin{array}{lll}7 & 2 & 3 \\
5 & 4 & 0 \\
7 & 1 & 5 \\
5 & 7 & 5 \\
6 & 7 & 3\end{array}$ & $\begin{array}{r}619 \\
615 \\
625 \\
562 \\
660\end{array}$ & $\begin{array}{l}836 \\
828 \\
878 \\
804 \\
859\end{array}$ & 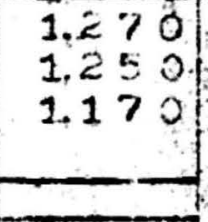 & $\begin{array}{l}7700 \\
3380 \\
3140 \\
2820 \\
3760\end{array}$ & $\begin{array}{llll}5 & 3 & 6 & 0 \\
5 & 2 & 0 & 0 \\
5 & 0 & 3 & 0 \\
5 & 2 & 0 & 0 \\
6 & 3 & 0 & 0\end{array}$ & $\begin{array}{l}6.20 \\
7680 \\
6,520 \\
7,110 \\
8100\end{array}$ & $\begin{array}{l}5060 \\
427 \\
383 \\
370 \\
3320\end{array}$ & 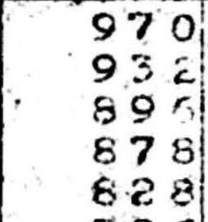 & $\begin{array}{l}649 \\
63 \\
642 \\
64 \\
64\end{array}$ & $\begin{array}{l}765 \\
750 \\
735 \\
735 \\
728\end{array}$ \\
\hline
\end{tabular}

\begin{tabular}{|c|c|c|c|c|c|c|c|c|c|c|c|}
\hline $\begin{array}{l}\text { XEN: } \\
\text { CARE- }\end{array}$ & $\frac{600}{87,110}$ & $\frac{723}{42,440}$ & $-\frac{685}{42,100}$ & $\frac{1,89}{88,510}$ & $\frac{3,206}{137,000}$ & $\frac{2.902^{2}}{146,200}$ & $\frac{1,485}{266,900}$ & $\frac{1.096}{172,000}$ & $\frac{0,050}{860,200}$ & $\frac{1,6 x}{126,500}$ & \begin{tabular}{c|c|c|} 
& 703 \\
18,210 & 0,230
\end{tabular} \\
\hline
\end{tabular}




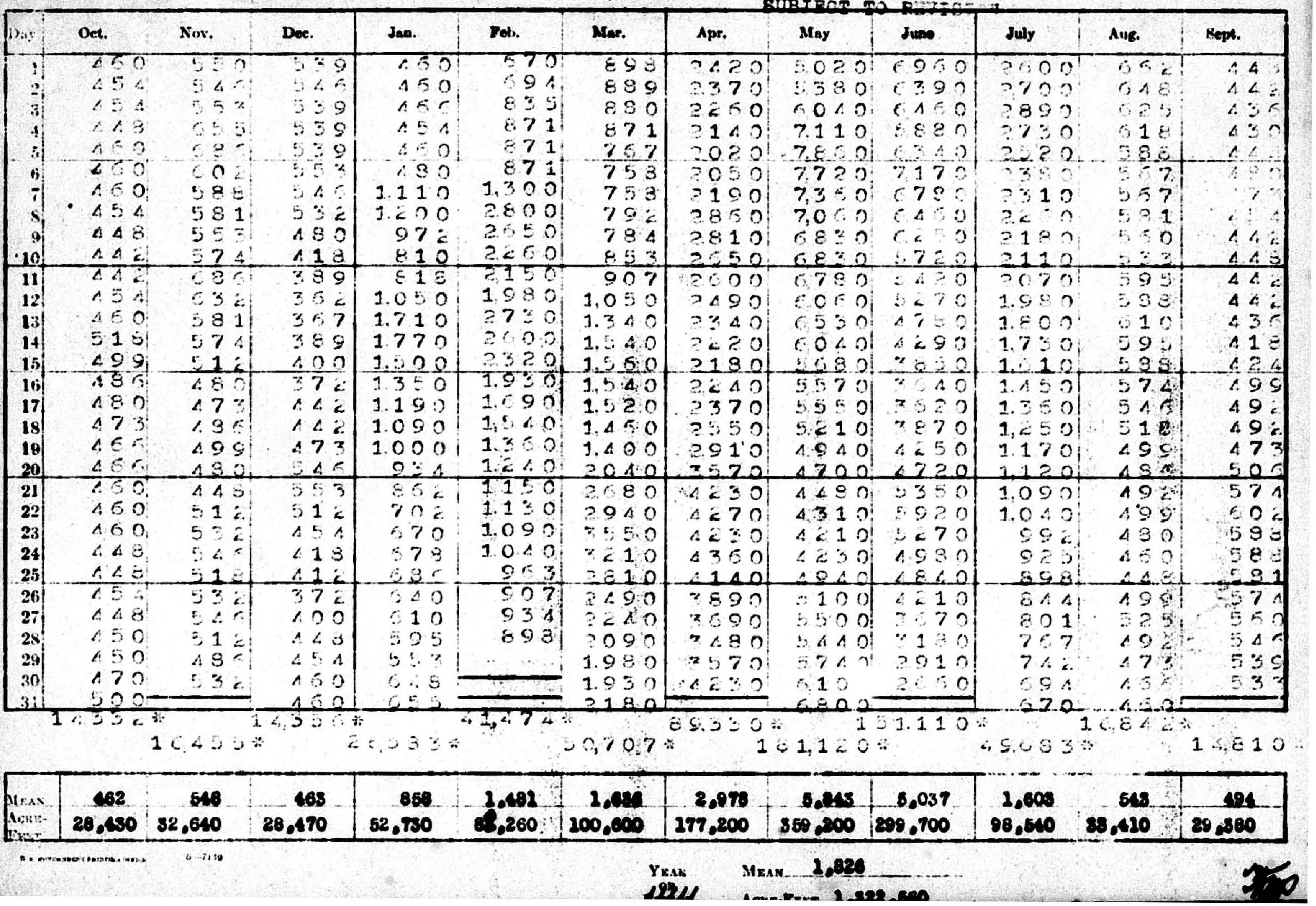




\section{$-2110$}

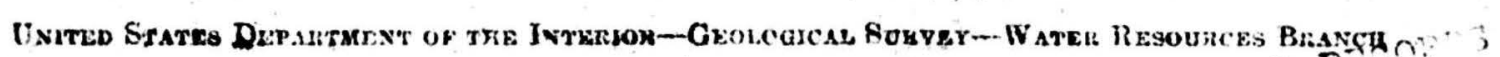

vile No. 2848

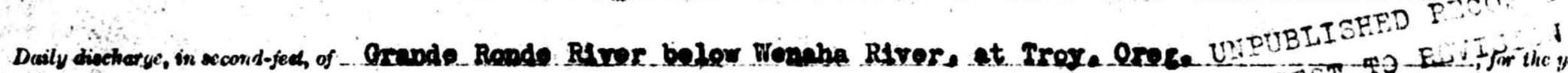

yesor ending Seplembier 50,194

\begin{tabular}{|c|c|c|c|c|c|c|c|c|c|c|c|c|}
\hline Day & - Oct. & Nor. & Doo. & Jan. & leh. & Mar. & Apr. & May & June & Juls & Aug. & Rept. \\
\hline $\begin{array}{l}1 \\
2 \\
3 \\
4 \\
5\end{array}$ & $\begin{array}{l}6 \\
-6\end{array}$ & & $\therefore$ & . & & $\therefore$ & & & & & & $\begin{array}{r}528 \\
523 \\
523 \\
551 \\
529\end{array}$ \\
\hline $\begin{array}{r}0 \\
7 \\
8 \\
0 \\
10\end{array}$ & $\therefore$ & & 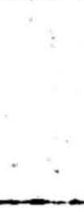 & $\because$ & & & & $\therefore$ & & & & $\begin{array}{ll}5 & 3 \\
51 & 1 \\
5 & 01 \\
5 & 01 \\
4 & 9\end{array}$ \\
\hline $\begin{array}{l}11 \\
12 \\
13 \\
14 \\
15\end{array}$ & . & & & . & & . & & & & & $\begin{array}{l}. \\
. \\
\end{array}$ & $\begin{array}{l}470 \\
405 \\
501 \\
31 \\
224\end{array}$ \\
\hline $\begin{array}{l}16 \\
17 \\
18 \\
19 \\
20 \\
\end{array}$ & $\therefore$ & & $z$ & . & & & & & & . & $\begin{array}{l}50 \\
551 \\
565 \\
55\end{array}$ & $\begin{array}{l}553 \\
612 \\
619 \\
631 \\
52 \\
5\end{array}$ \\
\hline $\begin{array}{l}21 \\
22 \\
23 \\
24 \\
25 \\
\end{array}$ & 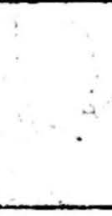 & & & & & . & & & & & $\begin{array}{lll}5 & 0 & 9 \\
5 & 5 & 9 \\
5 & 5 & 7 \\
5 & 5 & 7 \\
1 & 5 & 7\end{array}$ & $\begin{array}{l}557 \\
381 \\
640 \\
537 \\
59\end{array}$ \\
\hline $\begin{array}{l}26 \\
27 \\
28 \\
29 \\
30 \\
31 \\
\end{array}$ & . & & $\because$ & . & 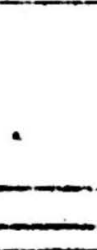 & & . & & & & $\begin{array}{lll}5 & 5 & 7 \\
5 & 5 & 7 \\
5 & 5 & 7 \\
5 & 5 & 1 \\
5 & 3 & 4 \\
5 & 2 & 0\end{array}$ & $\begin{array}{l}575 \\
583 \\
557 \\
553 \\
501\end{array}$ \\
\hline
\end{tabular}

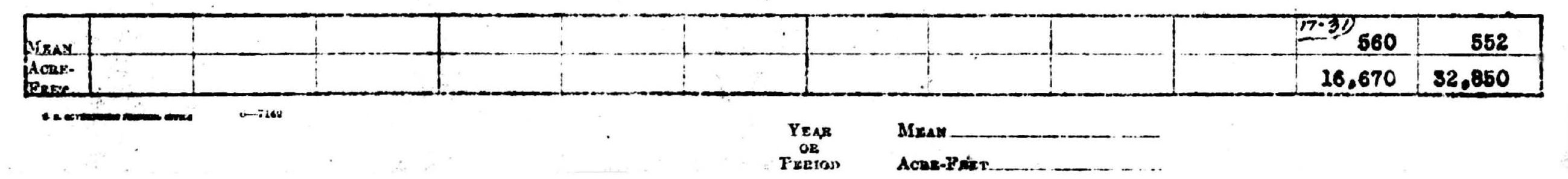




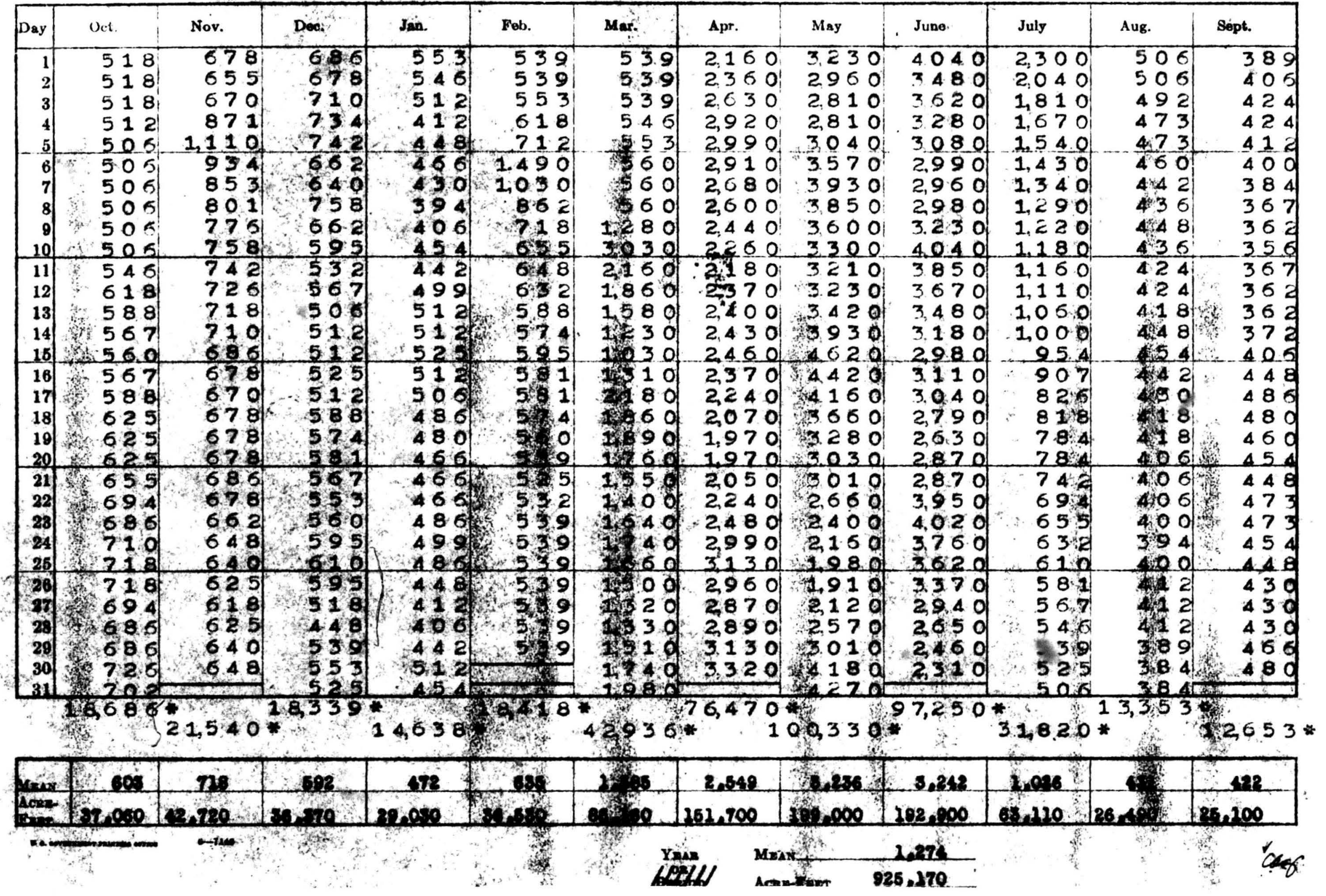


OFFICE OF STATE ENGINEER-STATE OF OREGON-WATER RESOURCES DEPARTMENTJECT TO REITSE File Number ...223. Daily discharge; in second-jeet, of ............................tilia River et Pendleton, Oreg. , for the year ending September 30, $19 . .44$

\begin{tabular}{|c|c|c|c|c|c|c|c|c|c|c|c|c|}
\hline Day & Oct. & Nos. & ec. & an. & Feb. & Mar. & April & May & June & July & Lus. & Sept. \\
\hline $\begin{array}{r}1 \\
2 \\
3 \\
4 \\
5 \\
6 \\
7 \\
8 \\
9 \\
10\end{array}$ & $\begin{array}{l}39 \\
40 \\
30 \\
41 \\
42 \\
44 \\
44 \\
40 \\
41 \\
42\end{array}$ & $\begin{array}{rll}9 & 6 \\
9 & 1 \\
8 & 8 \\
1 & 0 & 7 \\
1 & 7 & 0 \\
1 & 6 & 3 \\
1 & 4 & 2 \\
1 & 3 & 2 \\
1 & 2 & 0 \\
1 & 1 & 3\end{array}$ & $\begin{array}{lll}7 & 8 \\
& 8 & 3 \\
1 & 4 & 3 \\
2 & 0 & 0 \\
2 & 2 & 8 \\
2 & 2 & 8 \\
2 & 1 & 6 \\
2 & 1 & 3 \\
2 & 2 & 5 \\
2 & 1 & 9\end{array}$ & $\begin{array}{lll}1 & 0 & 9 \\
1 & 1 & 1 \\
1 & 0 & 7 \\
1 & 0 & 6 \\
1 & 0 & 2 \\
1 & 0 & 2 \\
9 & 9 \\
9 & 4 \\
9 & 2 \\
9 & 1\end{array}$ & $\begin{array}{lll}1 & 0 & 2 \\
1 & 0 & 6 \\
1 & 2 & 2 \\
1 & 7 & 9 \\
2 & 2 & 2 \\
5 & 5 & 0 \\
8 & 7 & 6 \\
7 & 4 & 3 \\
5 & 8 & 0 \\
4 & 5 & 0\end{array}$ & $\begin{array}{rrr}2 & 9 & 7 \\
2 & 3 & 1 \\
3 & 1 & 3 \\
3 & 5 & 6 \\
3 & 9 & 0 \\
3 & 8 & 5 \\
4 & 1 & 0 \\
5 & 5 & 8 \\
2.3 & 9 & 0 \\
4,4 & 7 & 0\end{array}$ & 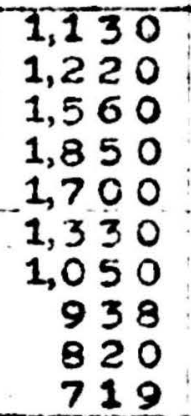 & $\begin{array}{r}1,130 \\
934 \\
806 \\
758 \\
758 \\
822 \\
798 \\
736 \\
587 \\
617\end{array}$ & $\begin{array}{lll}2 & 7 & 1 \\
2 & 7 & 5 \\
2 & 9 & 1 \\
2 & 8 & 8 \\
2 & 5 & 4 \\
2 & 3 & 1 \\
2 & 0 & 7 \\
2 & 0 & 2 \\
2 & 0 & 4 \\
1 & 9 & 2\end{array}$ & $\begin{array}{ll}6 & 2 \\
6 & 1 \\
5 & 3 \\
6 & 0 \\
6 & 0 \\
5 & 5 \\
5 & 1 \\
5 & 0\end{array}$ & $\begin{array}{ll}2 & 6 \\
2 & 6 \\
2 & 6 \\
2 & 7 \\
2 & 7 \\
2 & 5 \\
2 & 4 \\
2 & 8 \\
2 & 9\end{array}$ & $\begin{array}{ll}2 & 4 \\
3 & 0 \\
3 & 1 \\
3 & 1 \\
3 & 0 \\
2 & 8 \\
2 & 7 \\
2 & 7 \\
2 & 7\end{array}$ \\
\hline $\begin{array}{l}11 \\
12 \\
13 \\
14 \\
15 \\
16 \\
17 \\
13 \\
19 \\
20\end{array}$ & 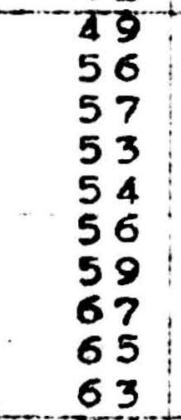 & $\begin{array}{r}104 \\
97 \\
94 \\
91 \\
89 \\
88 \\
85 \\
83 \\
81\end{array}$ & $\begin{array}{lll}2 & 0 & 5 \\
1 & 8 & 9 \\
1 & 7 & 5 \\
1 & 6 & 1 \\
1 & 5 & 3 \\
1 & 4 & 2 \\
1 & 3 & 4 \\
1 & 2 & 6 \\
1 & 2 & 2 \\
1 & 2 & 2\end{array}$ & 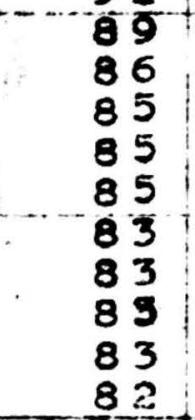 & $\begin{array}{lll}3 & 8 & 5 \\
3 & 4 & 8 \\
3 & 1 & 7 \\
3 & 1 & 3 \\
2 & 8 & 1 \\
2 & 8 & 5 \\
3 & 0 & 9 \\
2 & 9 & 7 \\
2 & 8 & 9 \\
2 & 7 & 3\end{array}$ & $\begin{array}{r}2,0 \\
1,2 \\
8 \\
5 \\
5 \\
4 \\
5 \\
1,2 \\
1,2 \\
1,0\end{array}$ & $\begin{array}{r}583 \\
827 \\
986 \\
1,140 \\
1,180 \\
1,180 \\
1,050 \\
990 \\
807 \\
855\end{array}$ & $\begin{array}{l}562 \\
503 \\
490 \\
508 \\
526 \\
502 \\
470 \\
425 \\
386 \\
350\end{array}$ & $\begin{array}{lll}1 & & 6 \\
1 & 6 & 9 \\
1 & 5 & 4 \\
1 & 4 & 5 \\
1 & 3 & 7 \\
1 & 2 & 6 \\
1 & 2 & 4 \\
1 & 3 & 9 \\
1 & 3 & 5 \\
1 & 2 & 6 \\
1 & 1 & 5\end{array}$ & $\begin{array}{ll}4 & \\
4 & 4 \\
42 \\
41 \\
41 \\
40 \\
37 \\
37 \\
36\end{array}$ & $\begin{array}{l}5 \\
2 \\
2 \\
2 \\
2 \\
3\end{array}$ & $\begin{array}{ll}2 & 5 \\
2 & 6 \\
2 & 5 \\
2 & 6 \\
2 & 7 \\
3 & 4 \\
3 & 9 \\
4 & 2 \\
4 & 4 \\
4 & 0\end{array}$ \\
\hline $\begin{array}{l}21 \\
22 \\
23 \\
24 \\
25 \\
20 \\
27 \\
28 \\
29 \\
30 \\
31\end{array}$ & $\begin{array}{r}76 \\
88 \\
83 \\
81 \\
81 \\
80 \\
77 \\
73 \\
74 \\
89 \\
100 \\
\end{array}$ & $\begin{array}{l}81 \\
80 \\
80 \\
80 \\
78 \\
77 \\
76 \\
76 \\
76 \\
77 \\
\end{array}$ & $\begin{array}{lll}1 & 1 & 5 \\
1 & 1 & 1 \\
1 & 0 & 9 \\
1 & 0 & 7 \\
1 & 1 & 1 \\
1 & 1 & 3 \\
1 & 1 & 3 \\
1 & 1 & 1 \\
1 & 1 & 1 \\
1 & 0 & 9 \\
1 & 0 & 7\end{array}$ & $\begin{array}{r}82 \\
82 \\
86 \\
102 \\
104 \\
106 \\
102 \\
97 \\
102 \\
102 \\
102 \\
\end{array}$ & $\begin{array}{l}269 \\
265 \\
249 \\
265 \\
293 \\
309 \\
309 \\
289 \\
305 \\
. \\
\end{array}$ & $\begin{array}{lll}8 & 2 & 7 \\
6 & 9 & 5 \\
6 & 9 & 5 \\
8 & 7 & 6 \\
8 & 4 & 8 \\
7 & 1 & 9 \\
7 & 9 & 6 \\
5 & 2 & 0 \\
5 & 3 & 6 \\
7 & 0 & 1 \\
9 & 7 & 8 \\
\end{array}$ & $\begin{array}{l}1,090 \\
1,790 \\
2,1600 \\
2,3000 \\
2,1330 \\
1,5990 \\
1,4400 \\
1,3500 \\
1,350 \\
1,300 \\
1 .\end{array}$ & $\begin{array}{lll}3 & 1 & 3 \\
2 & 9 & 1 \\
2 & 8 & 4 \\
2 & 6 & 7 \\
2 & 1 & 9 \\
2 & 3 & 4 \\
2 & 1 & 9 \\
2 & 1 & 2 \\
2 & 2 & 3 \\
2 & 3 & 9 \\
2 & 5 & 4\end{array}$ & $\begin{array}{r}106 \\
113 \\
104 \\
93 \\
37 \\
34 \\
80 \\
77 \\
72 \\
65 \\
\end{array}$ & $\begin{array}{r}31 \\
31 \\
31 \\
30 \\
28 \\
27 \\
24 \\
22 \\
24\end{array}$ & $\begin{array}{ll}2 & 7 \\
2 & 7 \\
2 & 7 \\
2 & 5 \\
2 & 5 \\
2 & 7 \\
2 & 7 \\
2 & 5 \\
2 & 4 \\
2 & 4 \\
2 & 4\end{array}$ & $\begin{array}{r}48 \\
44 \\
46 \\
14 \\
41 \\
40 \\
39 \\
38 \\
41 \\
46 \\
\end{array}$ \\
\hline & 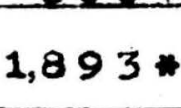 & 9224 & 5 & $5 *$ & 9 & $y 10$ & & $5 \frac{20}{50}$ & & 2.4 & $2 *$ & 763 \\
\hline a* & 61.1 & 97.4 & 148 & & & 80 & 1,284 & & 156 & 40.7 & 26.2 & 34.5 \\
\hline & 3750 & 5800 & 9090 & 3800 & 19,000 & 55420 & 76,990 & 30,860 & 9250 & 2510 & $6 / 0$ & 2050 \\
\hline
\end{tabular}




\section{BUBJBCE TO BSVIJIOS Year...2944 \\ OFFICE OF STATE ENGINEER-STATE OF OREGON-WATER RESOURCES DEPARTMLENT}

File Number 2236

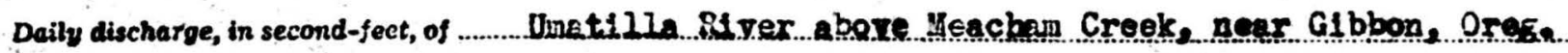

for the vear ending September 30, 1944

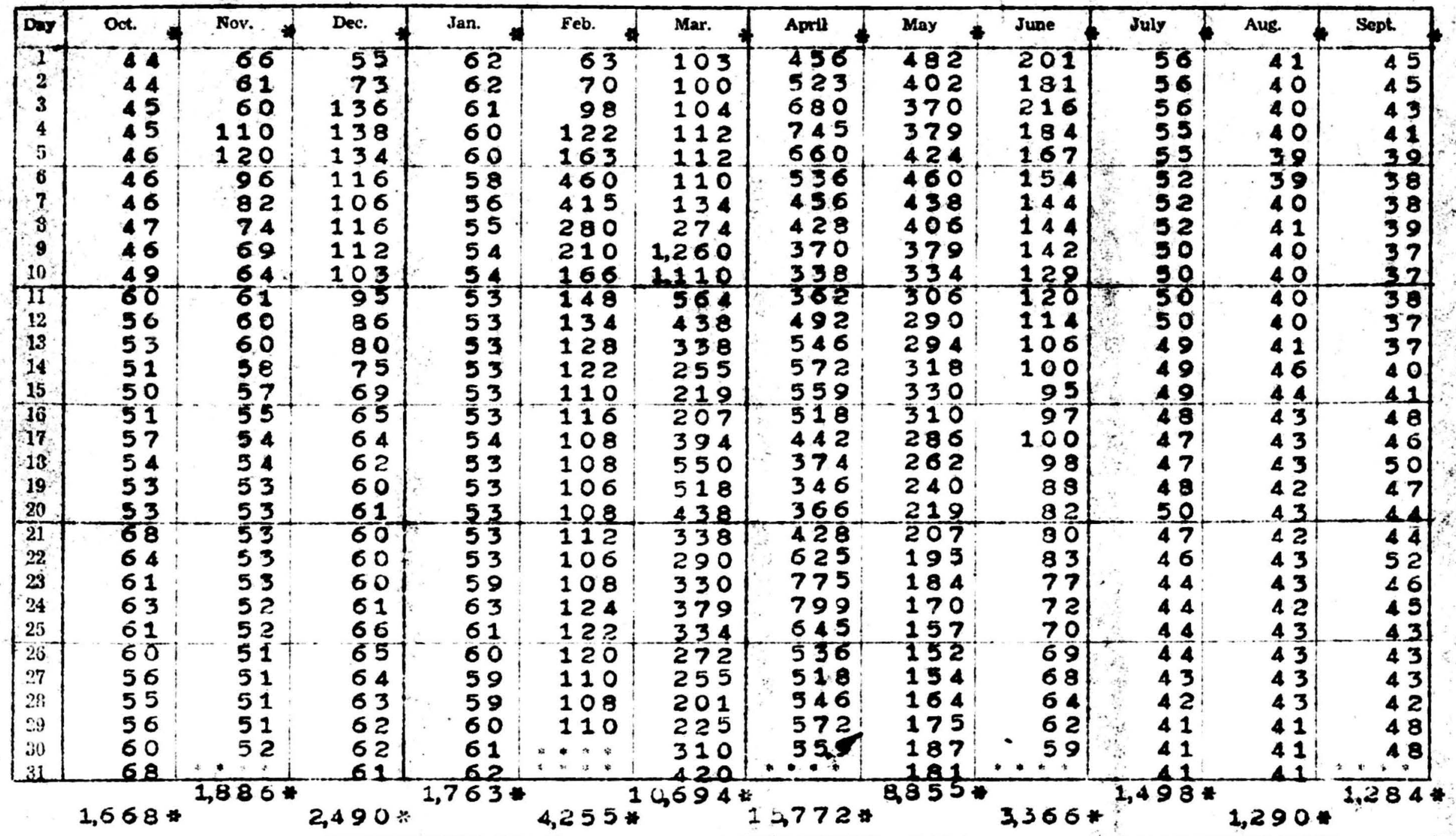

\begin{tabular}{|c|c|c|c|c|c|c|c|c|c|c|c|c|c|c|}
\hline mean & 538 & 629 & 803 & 569 & 147 & 345 & 526 & 286 & 112 & 483 & 416 & 42.8 \\
\hline $\operatorname{sen}$ & 3310 & 3240 & 4940 & 3500 & 8440 & 21210 & 31,280 & 17560 & 6680 & 2970 & 2560 & 2550 \\
\hline
\end{tabular}

Year

150
Acrean $. . .108,700$




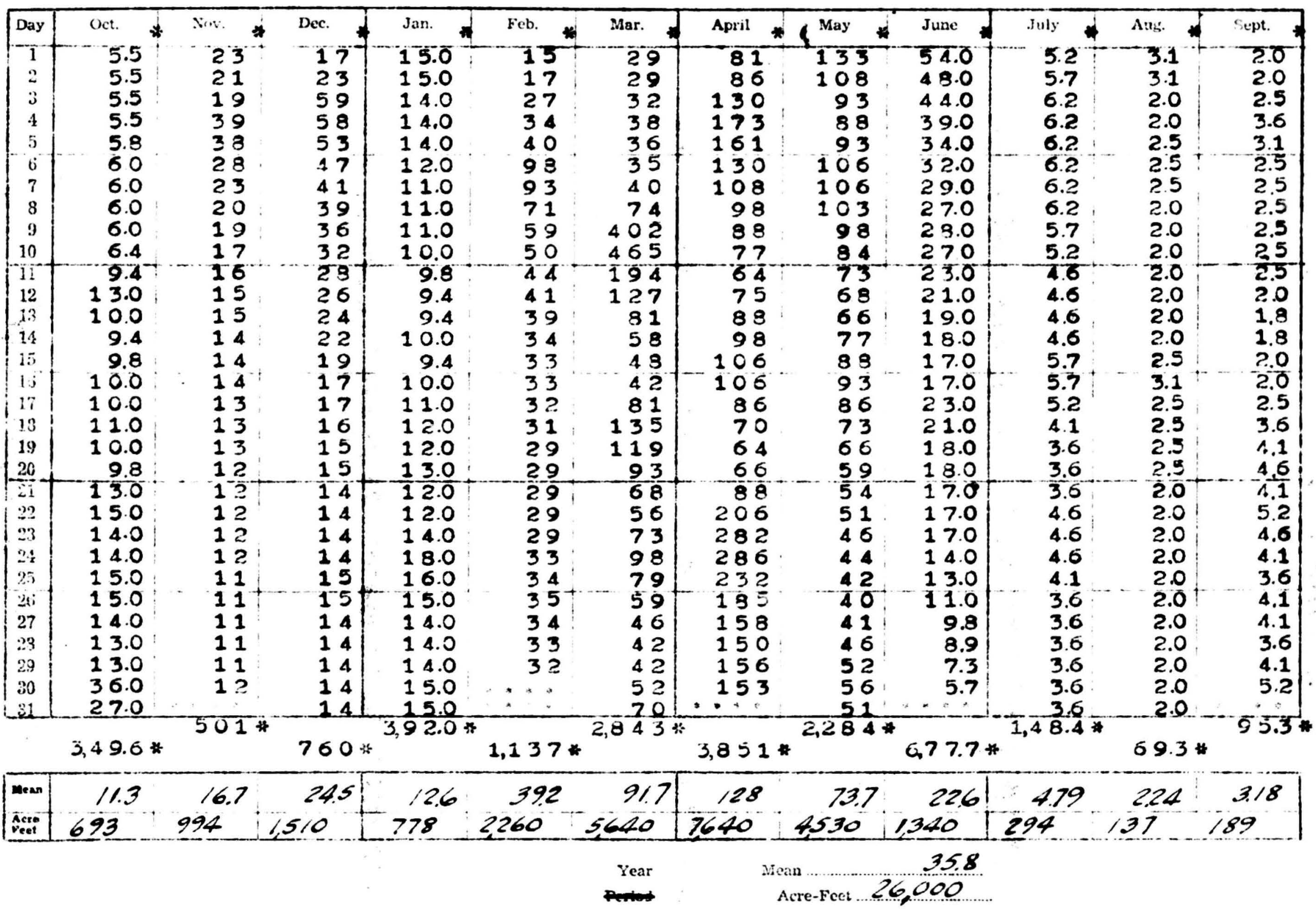




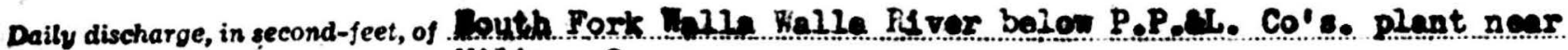
uilton, Ores.

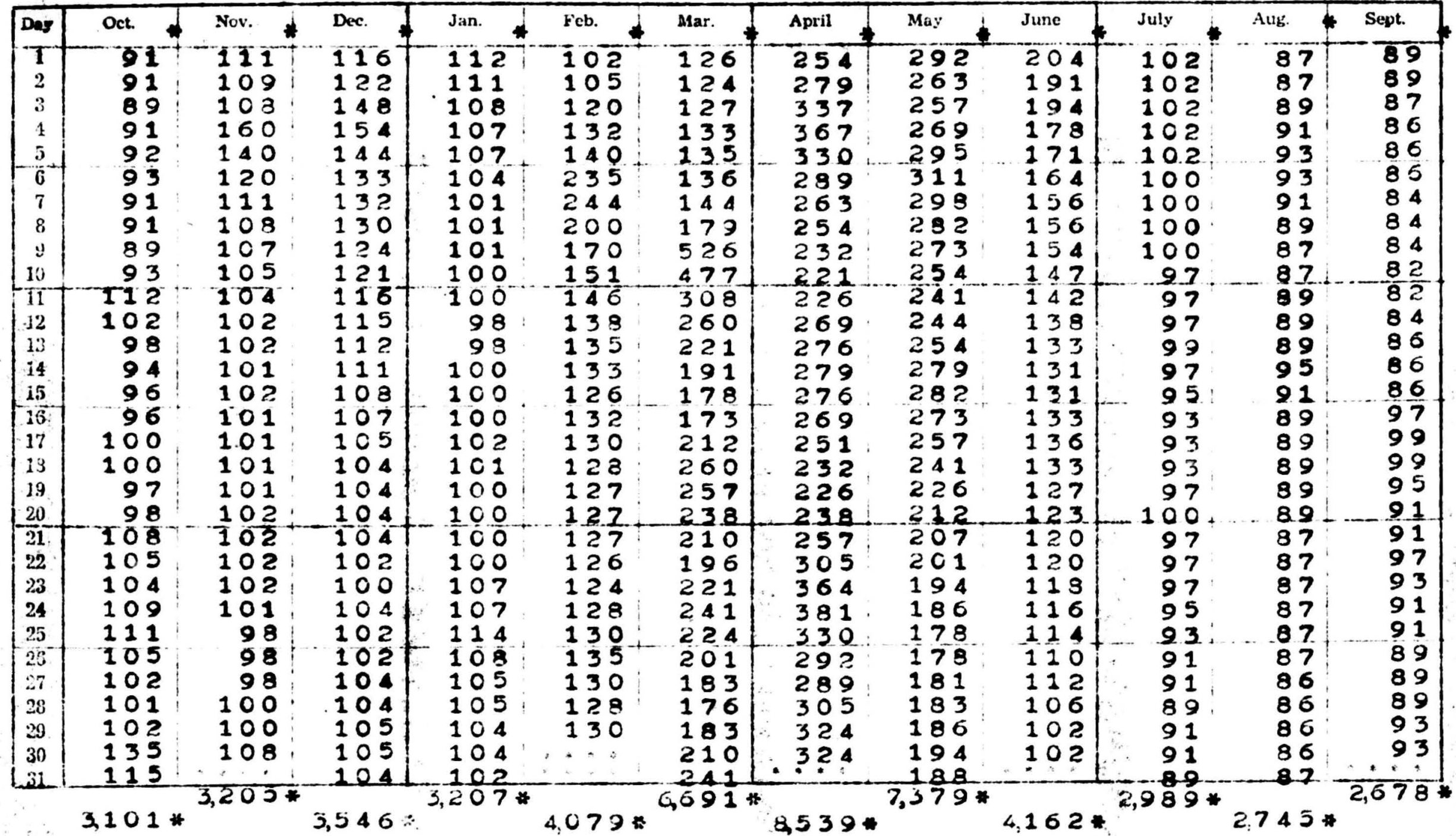

\begin{tabular}{|c|c|c|c|c|c|c|c|c|c|c|c|c|}
\hline mean & 100 & 107 & $1 / 4$ & 103 & 141 & 216 & 285 & 238 & 139 & 964 & 88.5 & 893 \\
\hline ice & $6 / 50$ & 6,360 & 72030 & 6,360 & 8,090 & 13270 & 16990 & 14600 & 8260 & 5,930 & 5440 & 5310 \\
\hline
\end{tabular}


Daily discharge, in second-feet, of ..... South Fork Valla Walle RAver near Mllton, Oreg. , for the yeer ending September 30, 1944

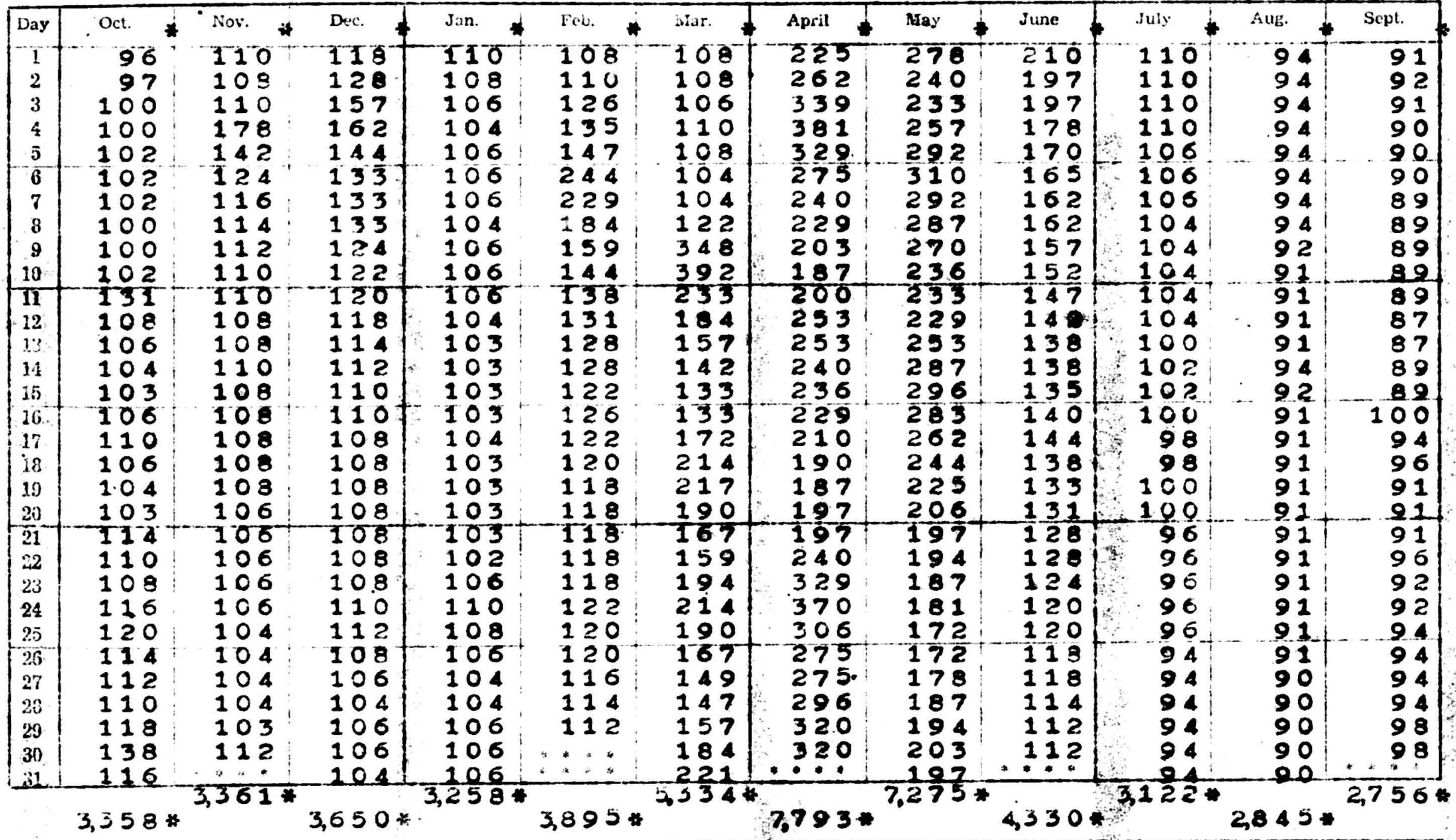

\begin{tabular}{|c|c|c|c|c|c|c|c|c|c|c|c|c|}
\hline & & 112 & 18 & 103 & 124 & 172 & 260 & 235 & 144 & 101 & 918 & 91.9 \\
\hline & 6660 & 6670 & 7240 & 6460 & 7730 & 10580 & 15460 & $14 \angle 30$ & 8590 & 6190 & 5620 & $54 \geq 0$ \\
\hline
\end{tabular}




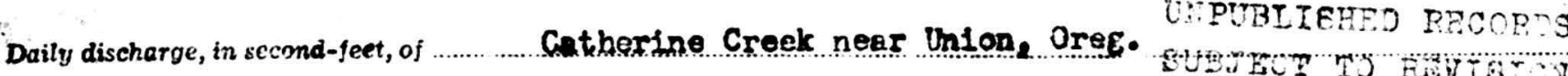

for tise year endizg Senturnit. 20,1944

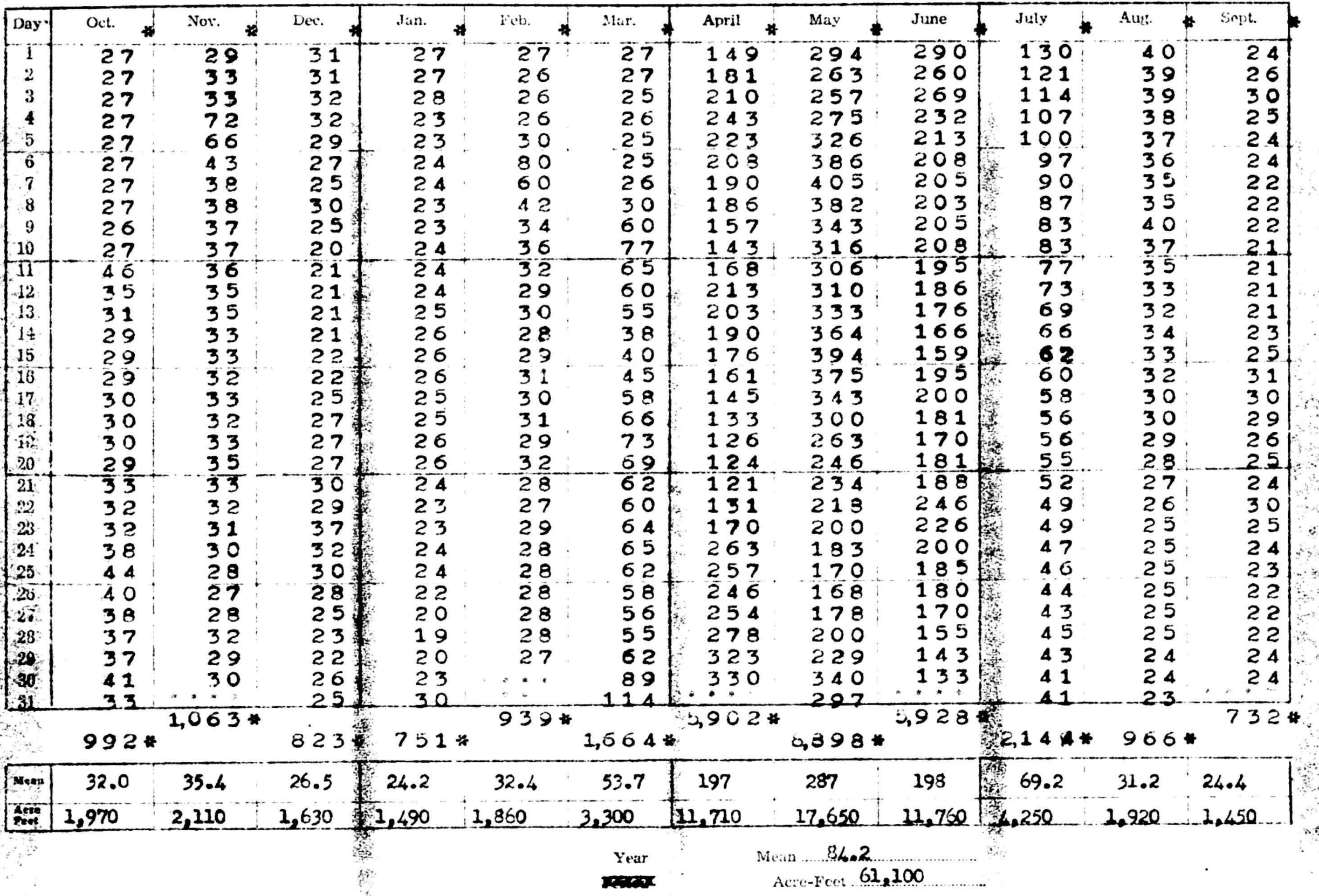




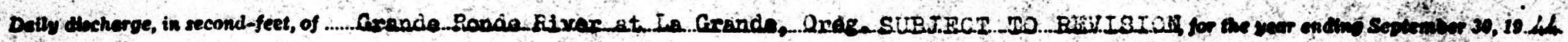

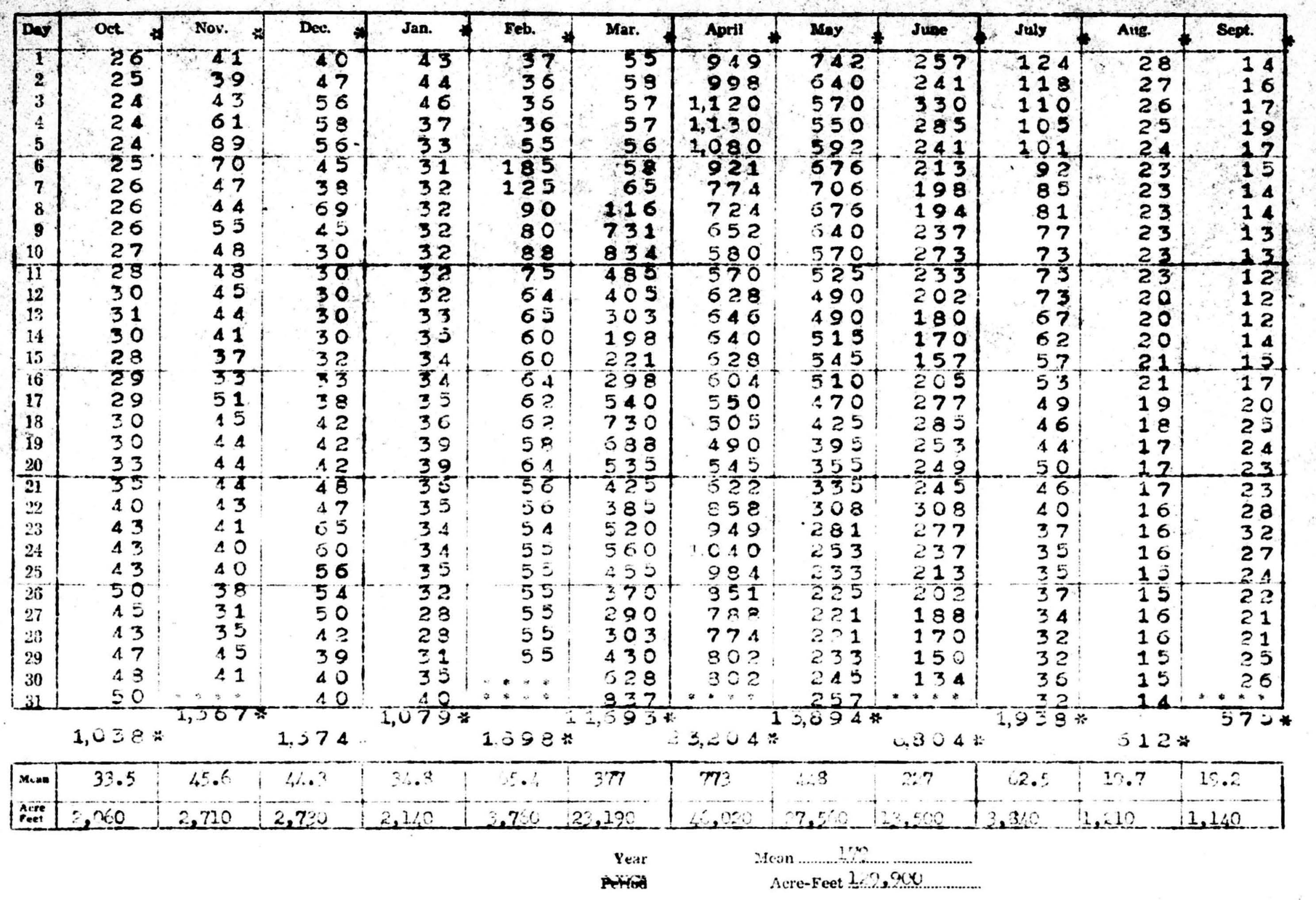




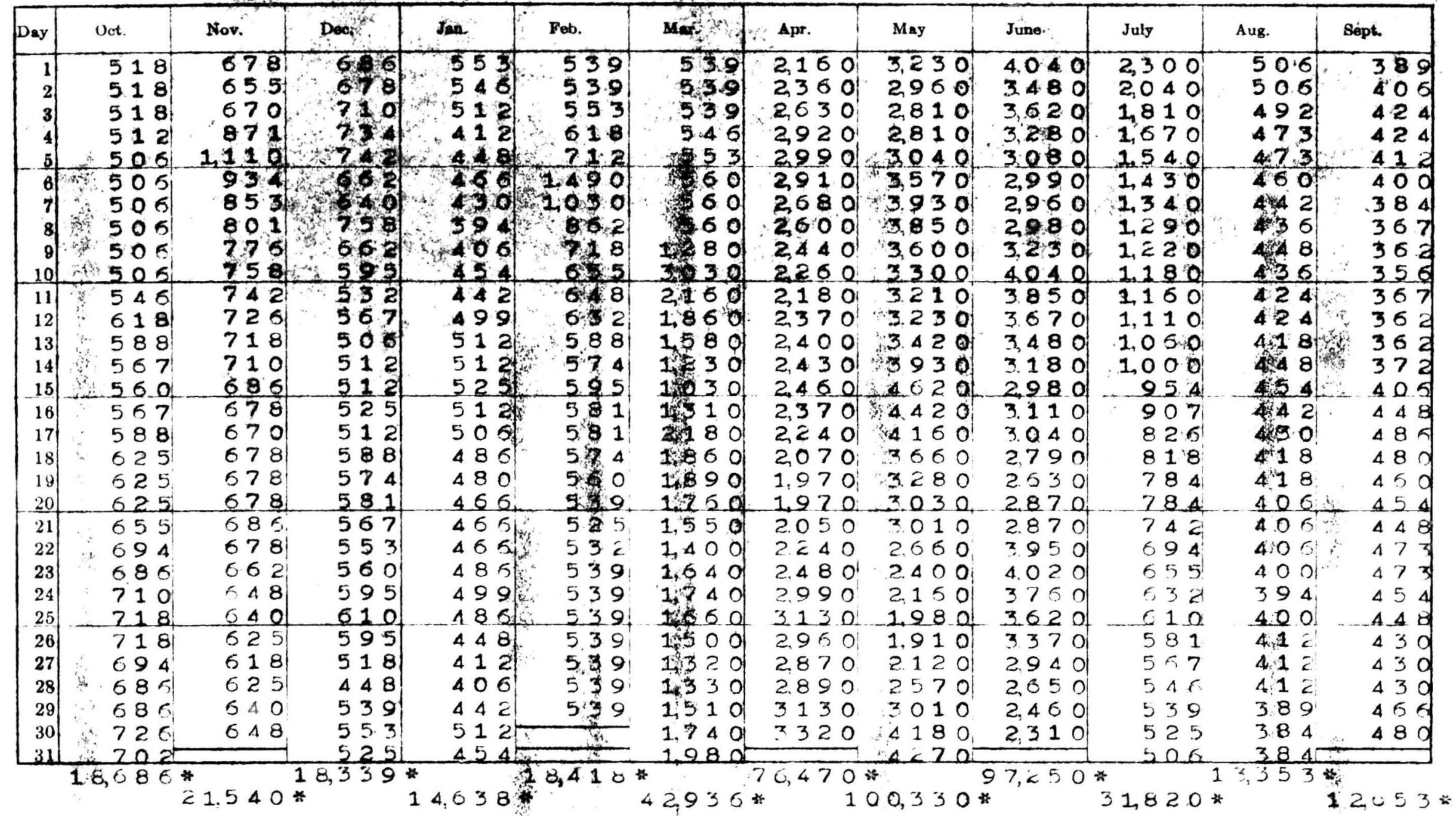

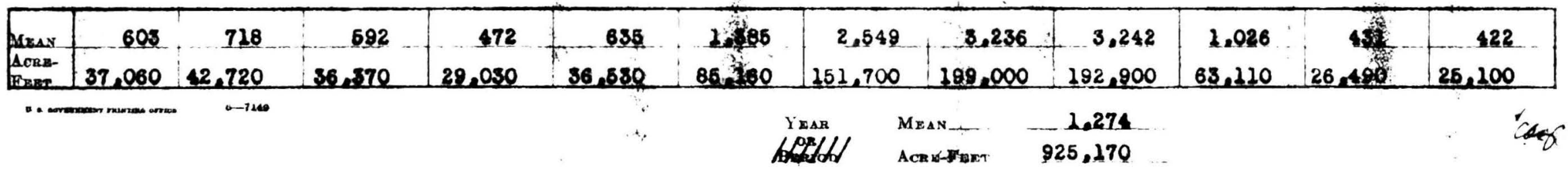




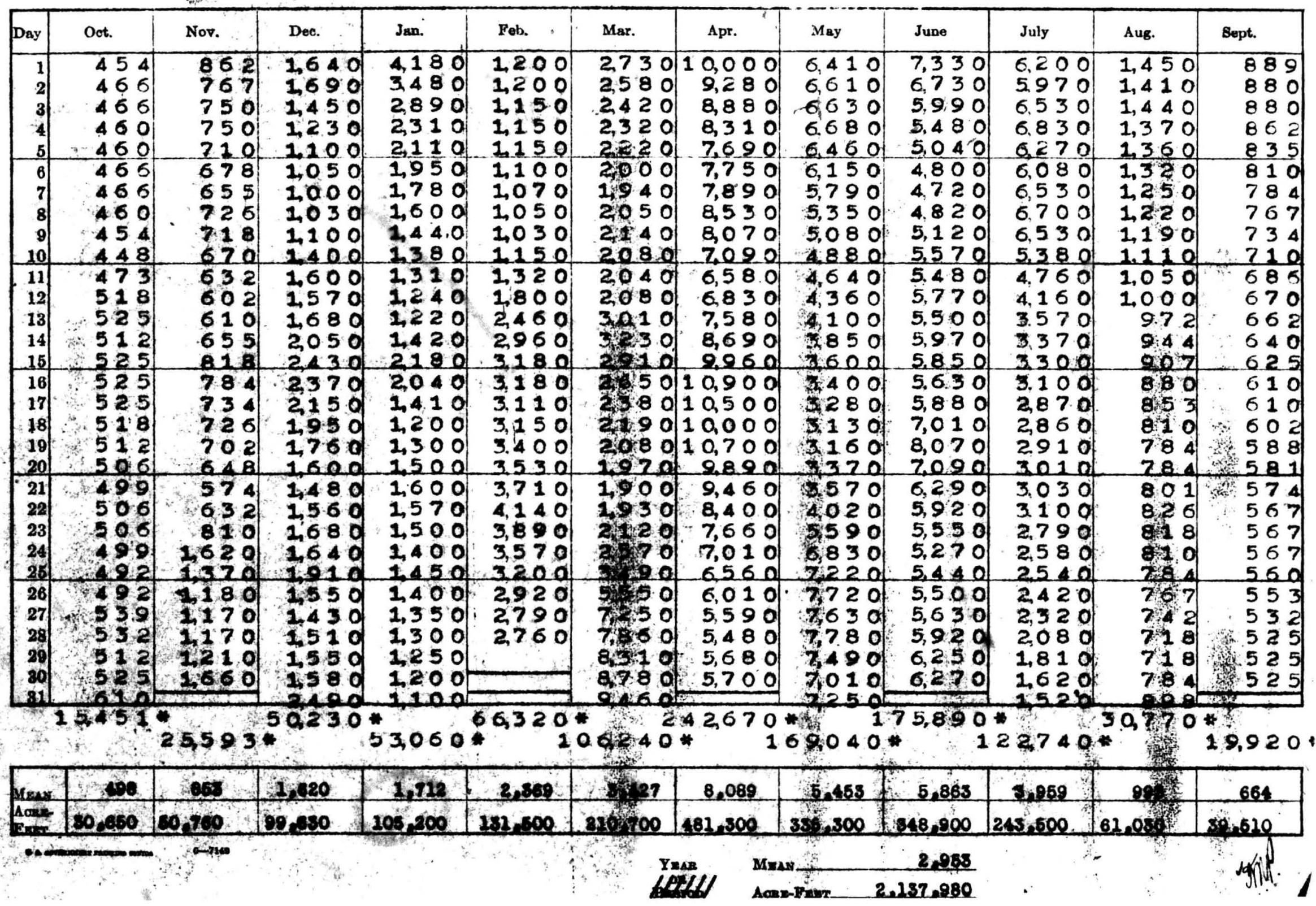




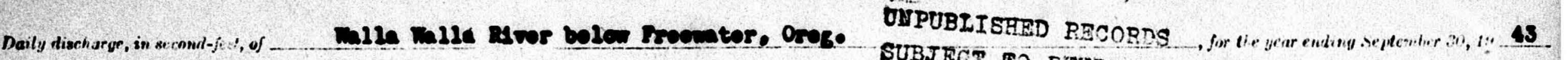

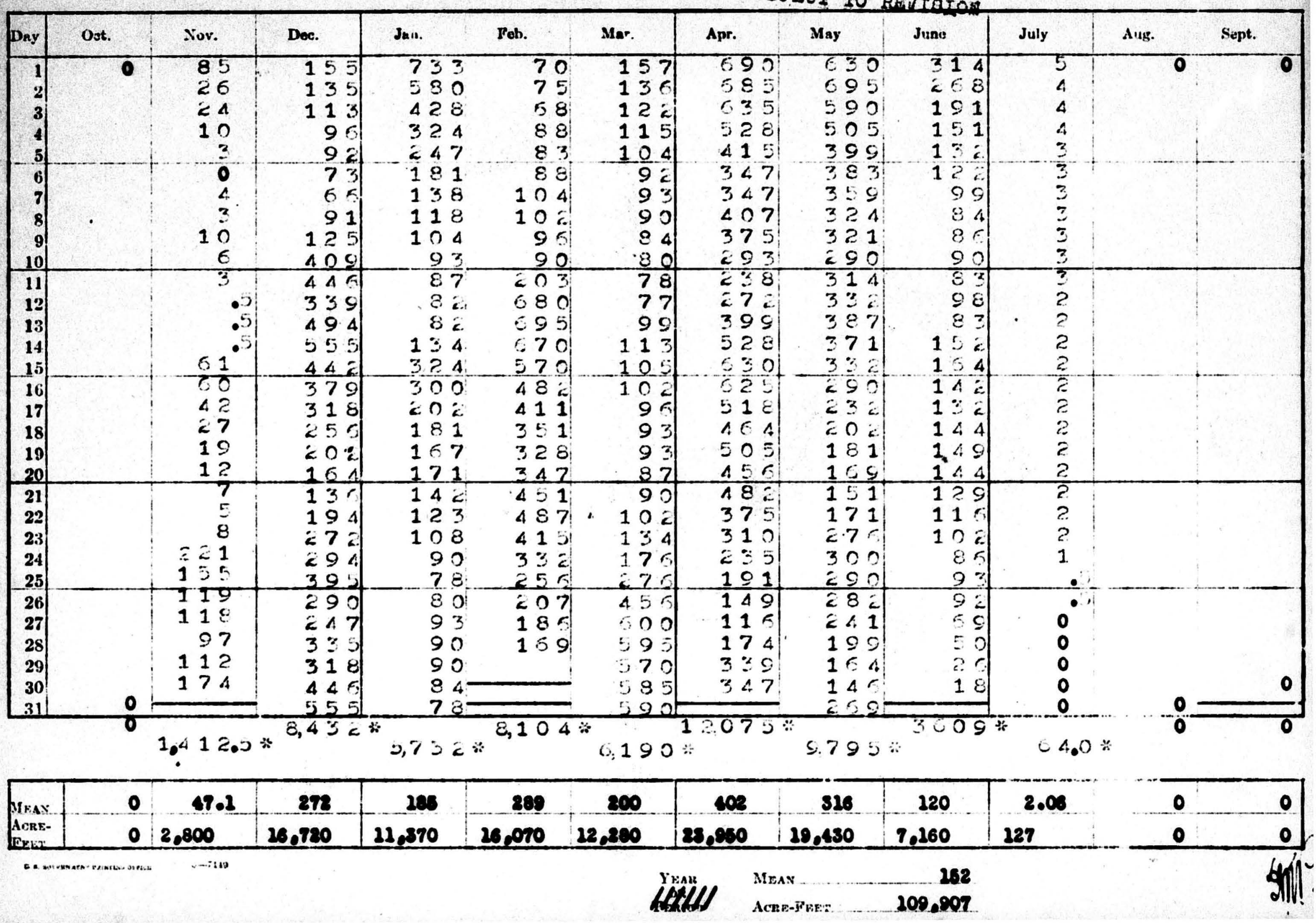


Inneose in Aore Bnet (therende)

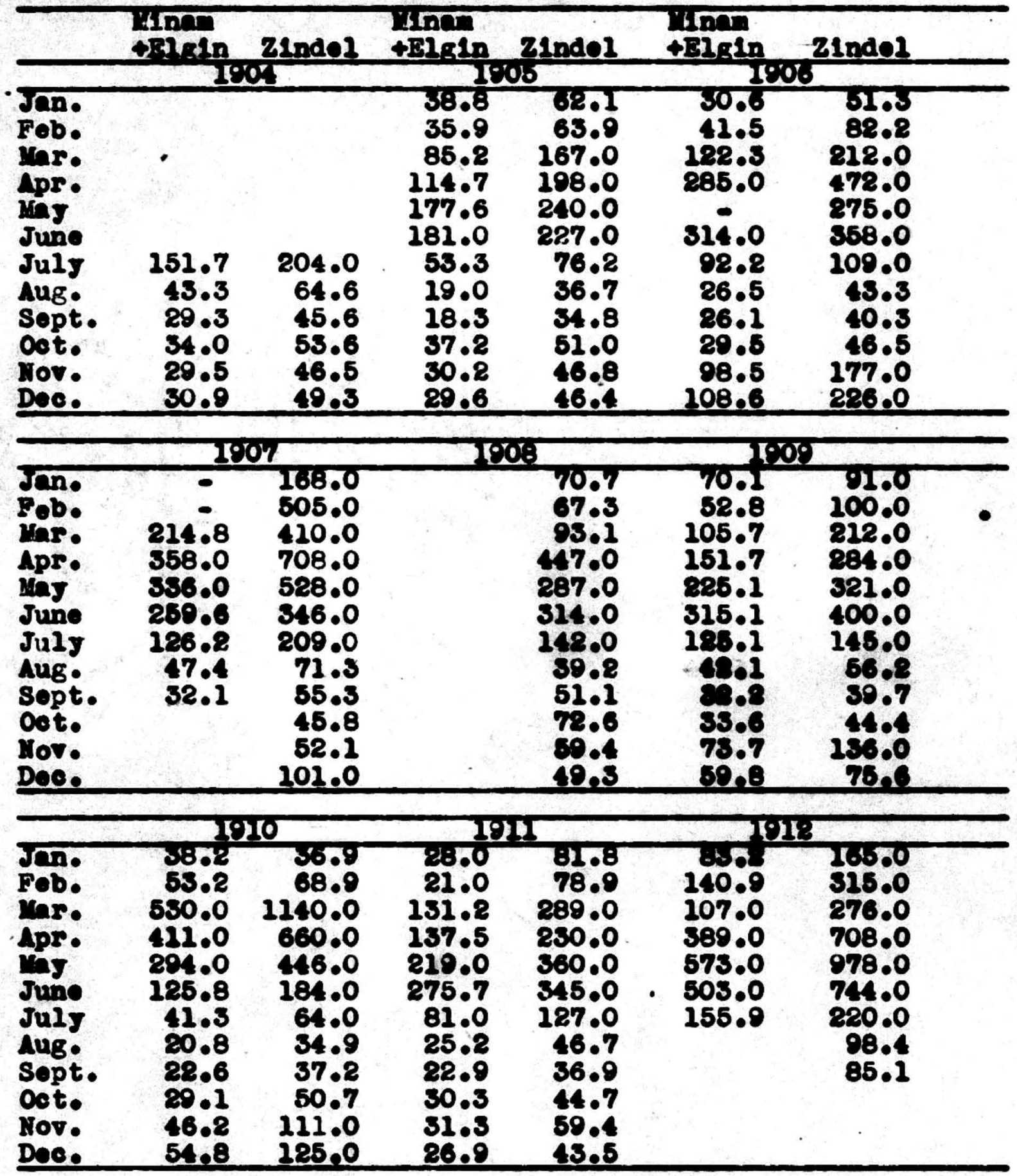




\section{IBUTARIES}

Sheep Pr dom rite

SHEET D
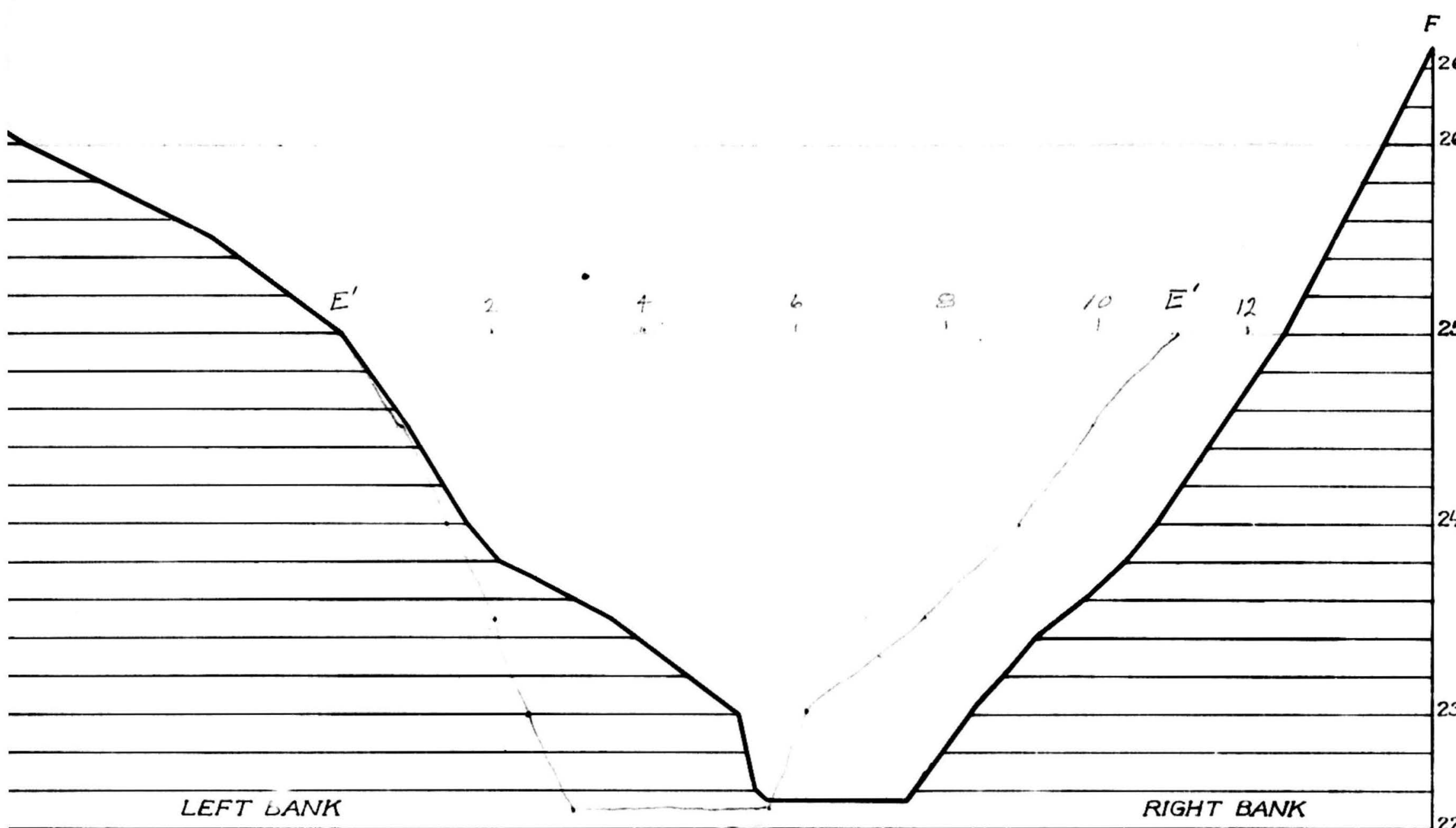

2640

20

2600

80

60

40

20

2500

80

60

40

20

2400

80

60

40

20

2300

80

60

2240

CROSS SECTION (.9.5 M.) 
Federal Power Commiseion fixed charges.

Interest percent

Imort 1

Replacement 0.17

Payments In lieu of taxes $\ldots \ldots \ldots .00$

Total-o-os $\frac{1.50}{5.50}$ percent

In comparison with the above, the following charges are used by the USED in 1ts computations 8

Interest $\ldots \ldots \ldots \ldots$

Amortizetion

Replacement:

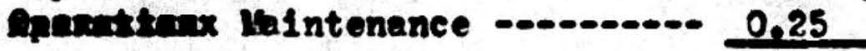

Hosume 30-year I1fe on small conerete iteme. A good carthen dam is assumed to have no depreciation. (No data on conerete dam depreciation)

Add to costs above shown an estimate of operation costs. In the case of one

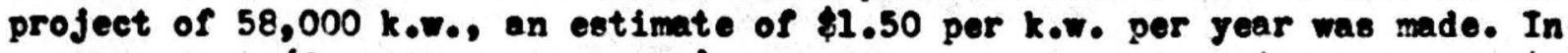
another case (Capacity not steted) operation was charged at $\$ 10,000$ plus $\$ 0,50$ per k.W. per year.

One project figured on basis of above totalled 5.04 percent annual charge to overall operation, maintenance, and replacemente.

\section{CONDUIT cosT (Illuetrative ceses)}

Food ateve pipe (Includes cost, erection, freight for 400 miles)

10-foot pipe, $10 \mathrm{w}$ pressure, $\$ 20$ per 1 ineal foot.

7-foot pipe, 20-foot heed, \$10 per Iineal foot.

7-foot pipe, 200-foot head, \$32 per Iineal foot.

The above costs are as of 1940(?). They do not include costs of excavation for footing or the costs of tresties.

GFNERATOR AND TURBINJ COSTS (as of 1942) (Deduct $10 \%$ for normal times!

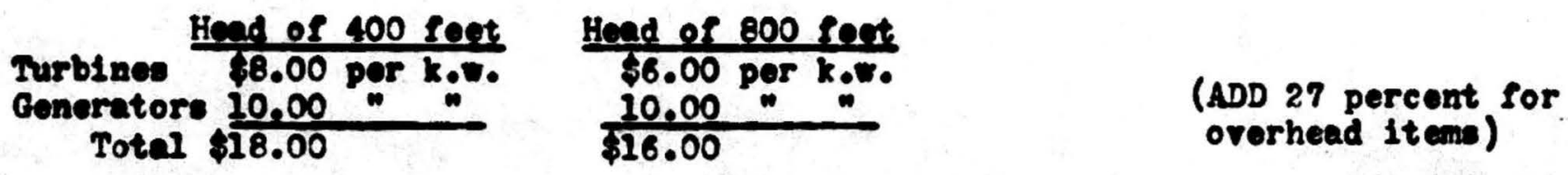

The above costs include installetion. Note that cost of turbines decreases with head. The cost of generatore my decrease elightly with head. Negligible

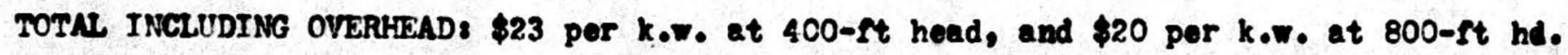




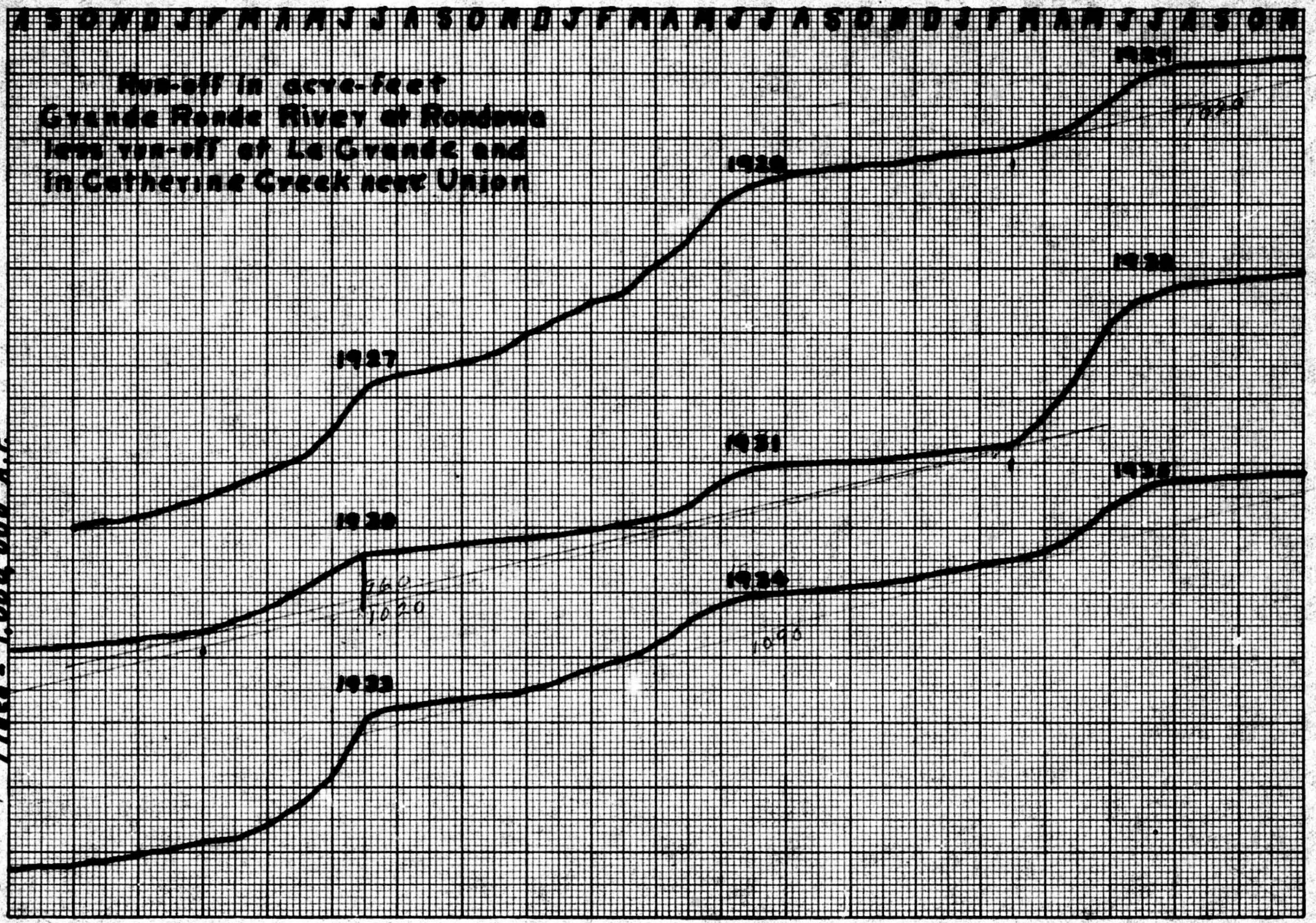



(1)

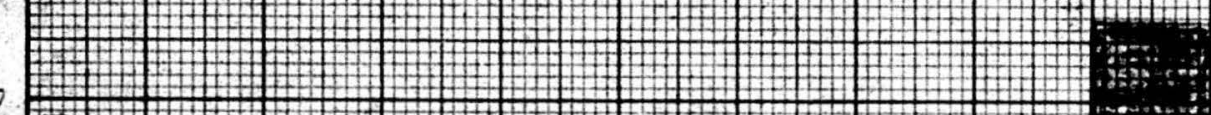

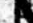

\#.

(1) (1)

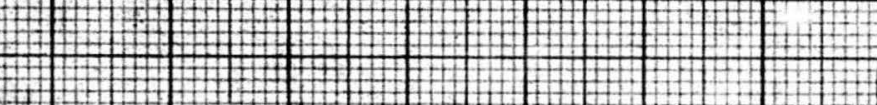

$+\cdots$ \#

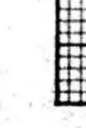

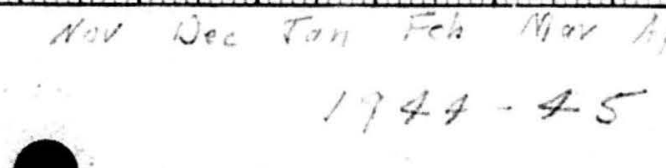


Grande Roude

Pandara

1

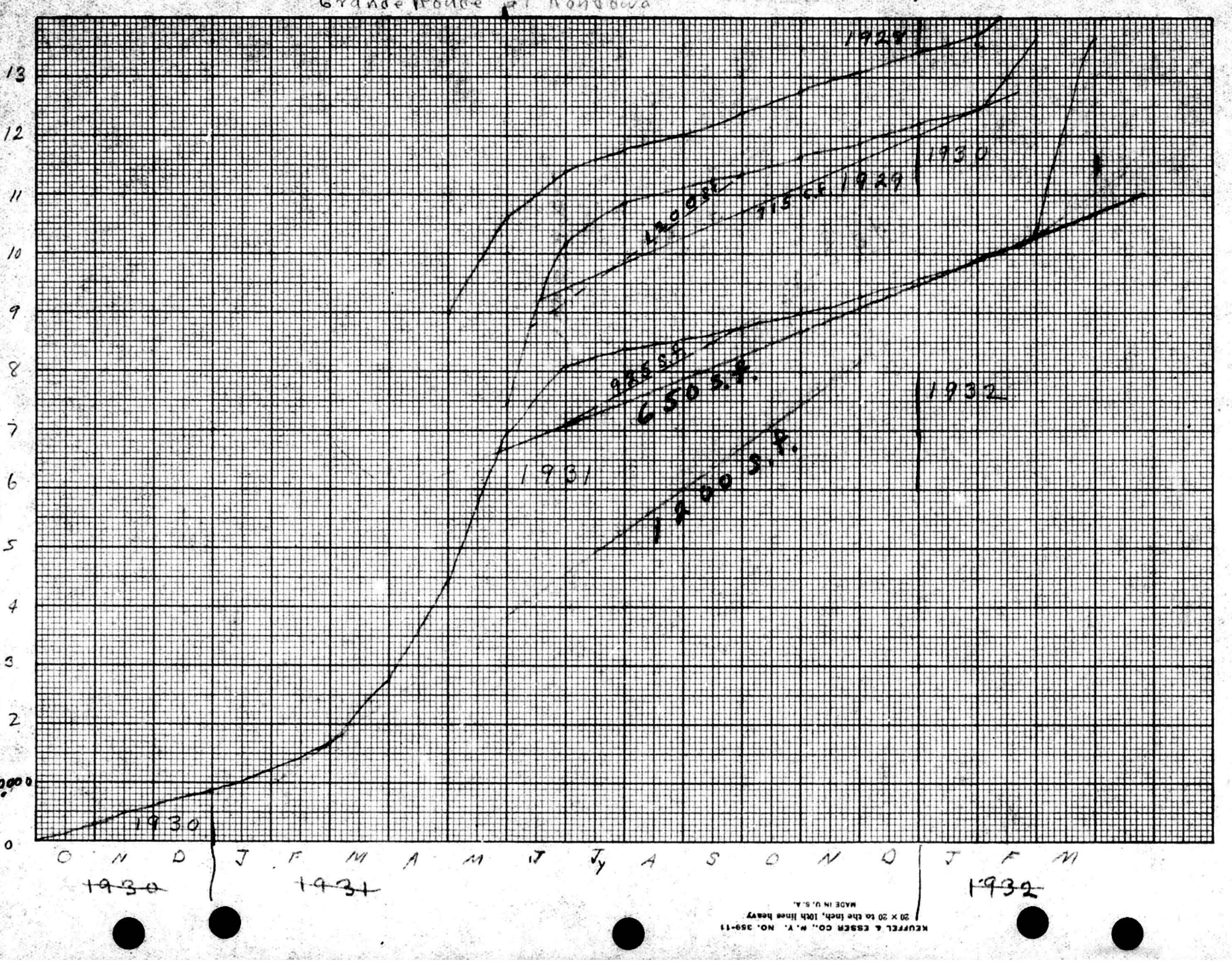




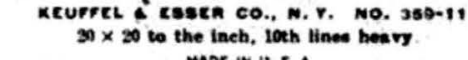

Presidval

0

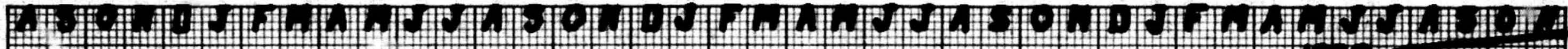

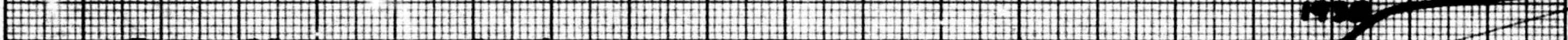
\#

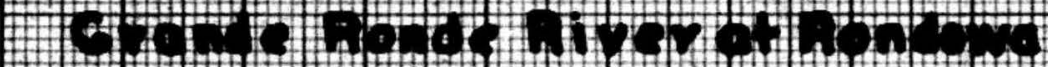

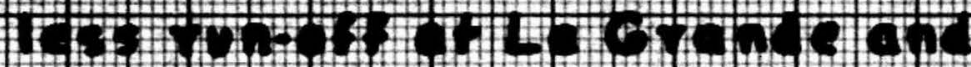

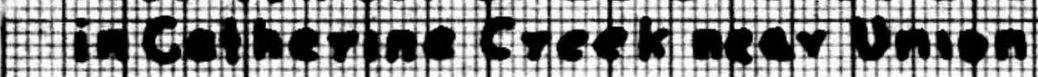

\section{$+$}

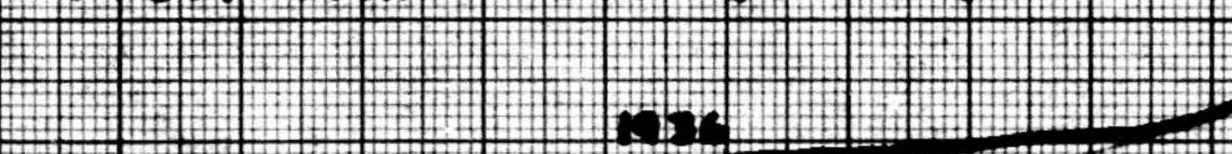

n.

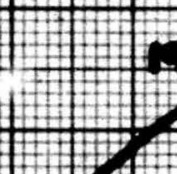

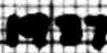

$+1$
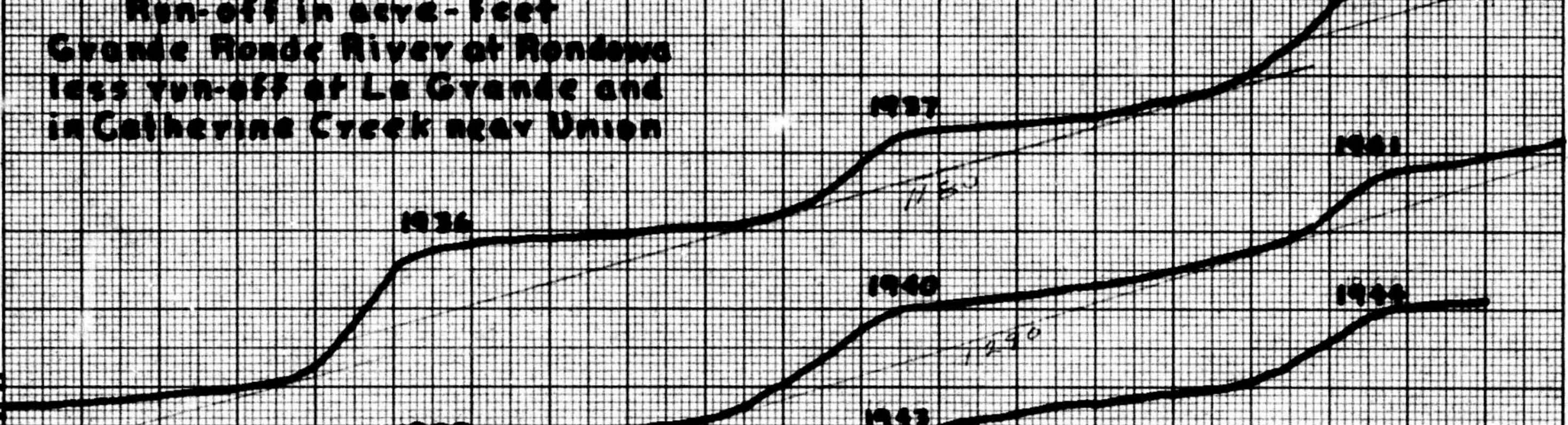

c.

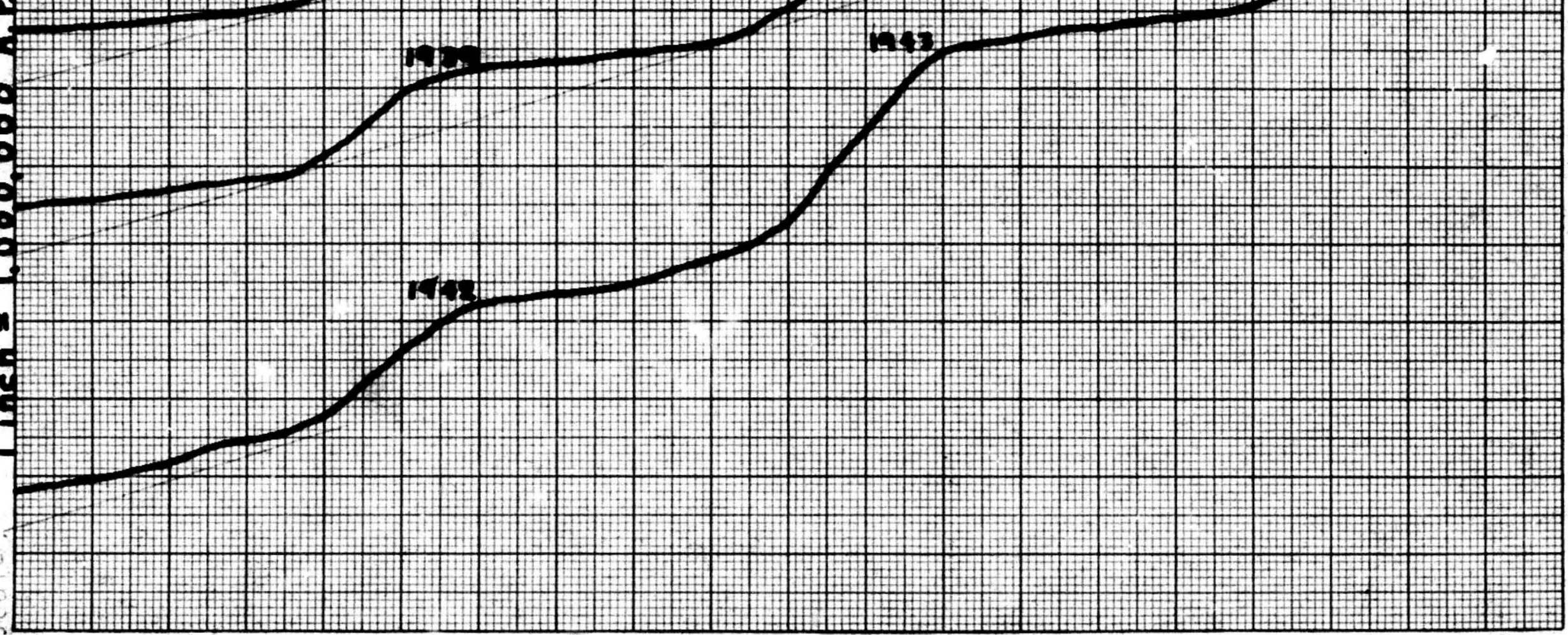




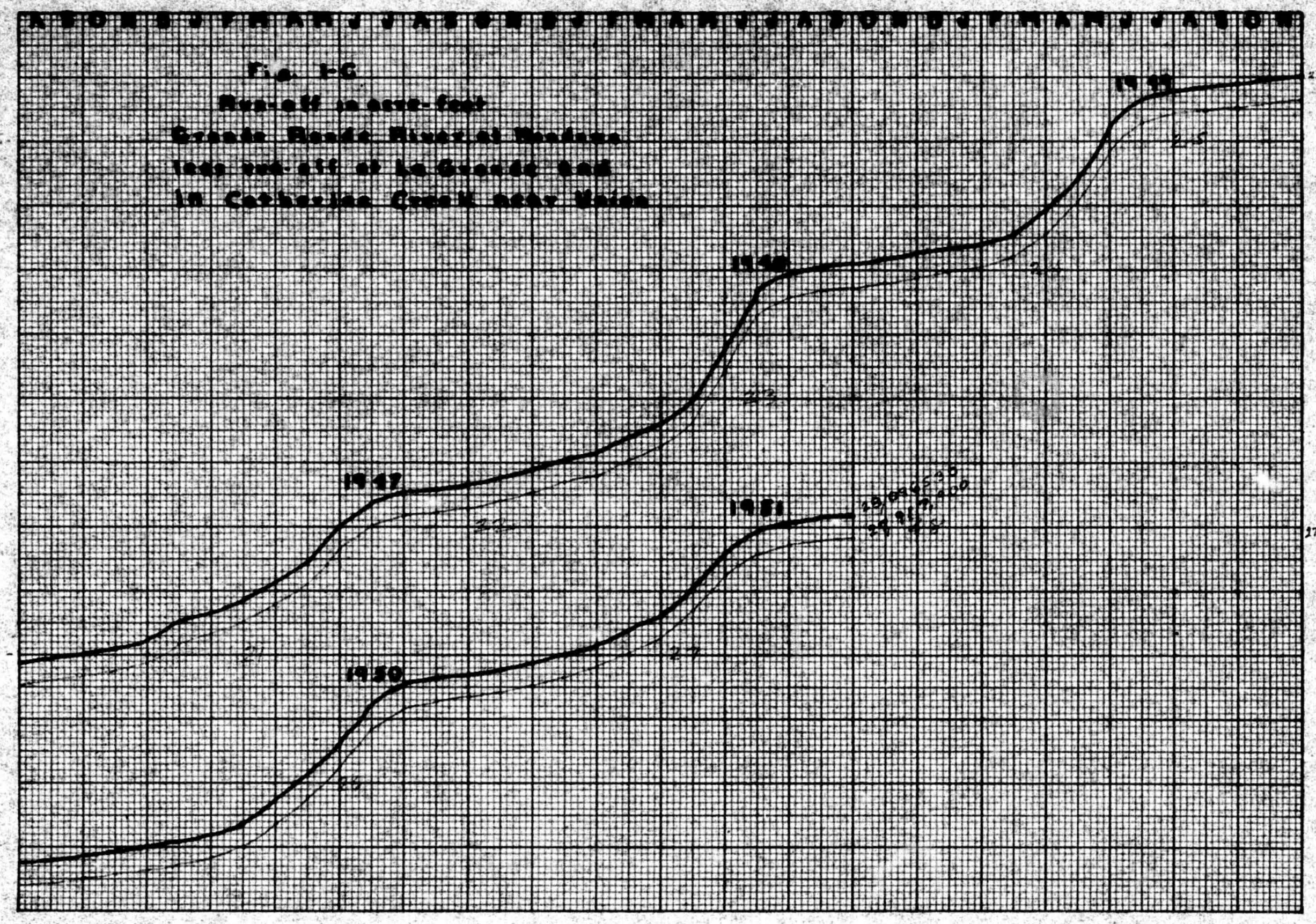



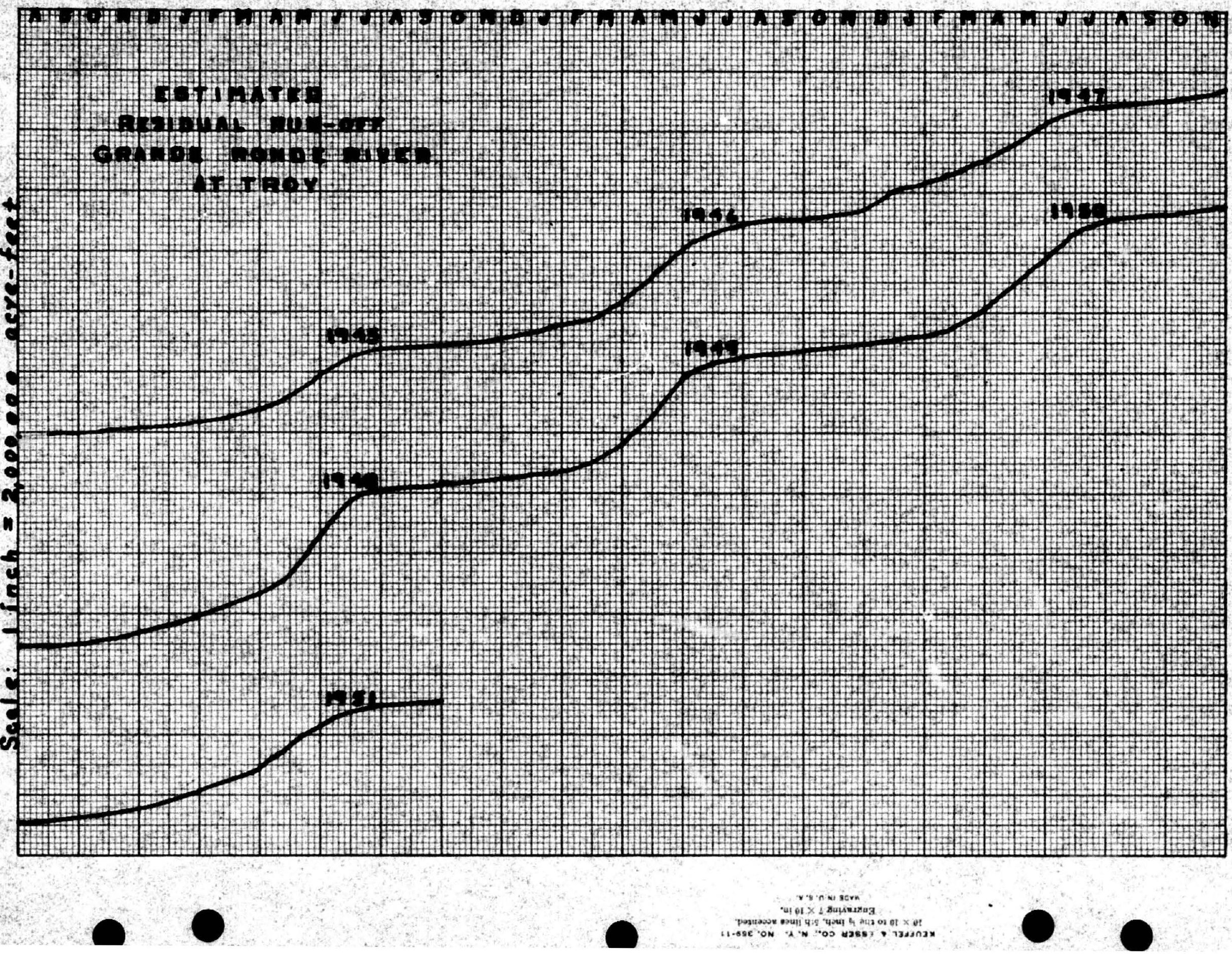


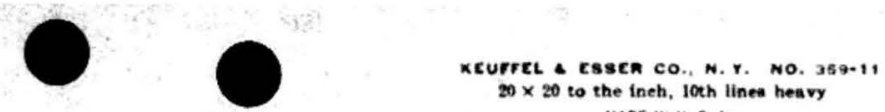
unoe in u. s.e.

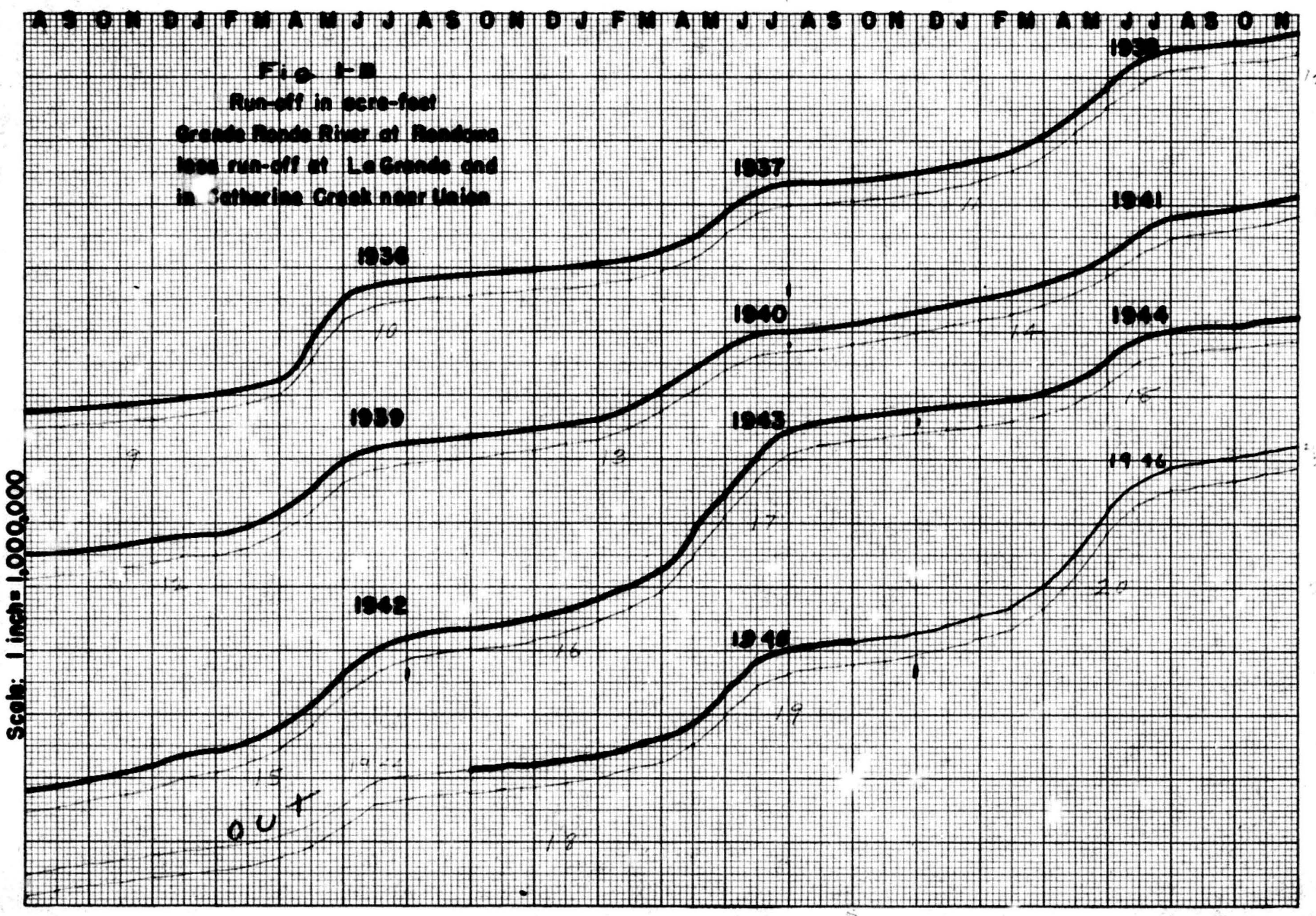


$S O N D J F M A M J J A S O N D J F M A M J J A S O N D J F M A M J J A S O N D$

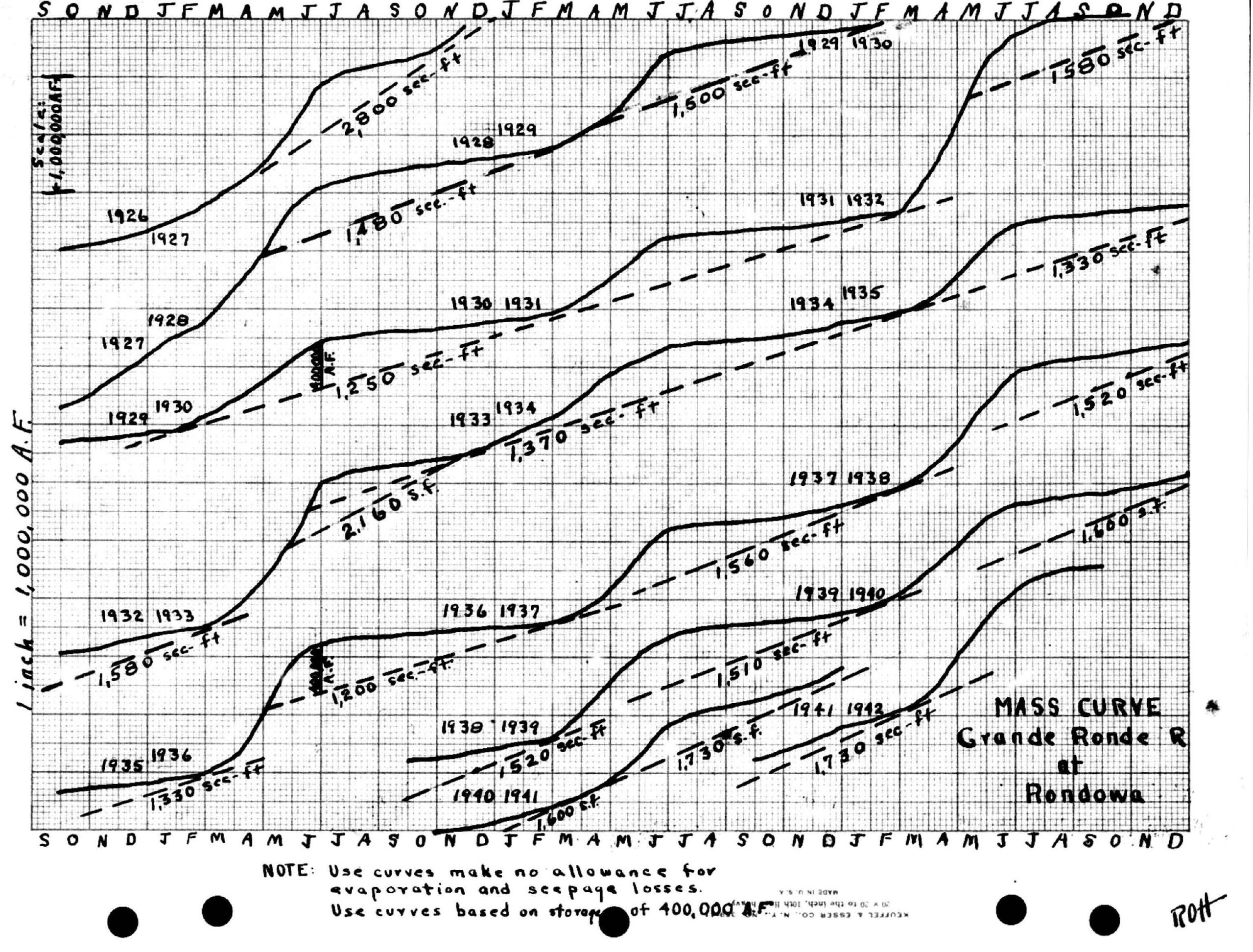




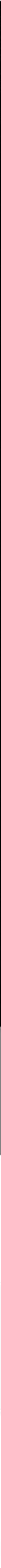





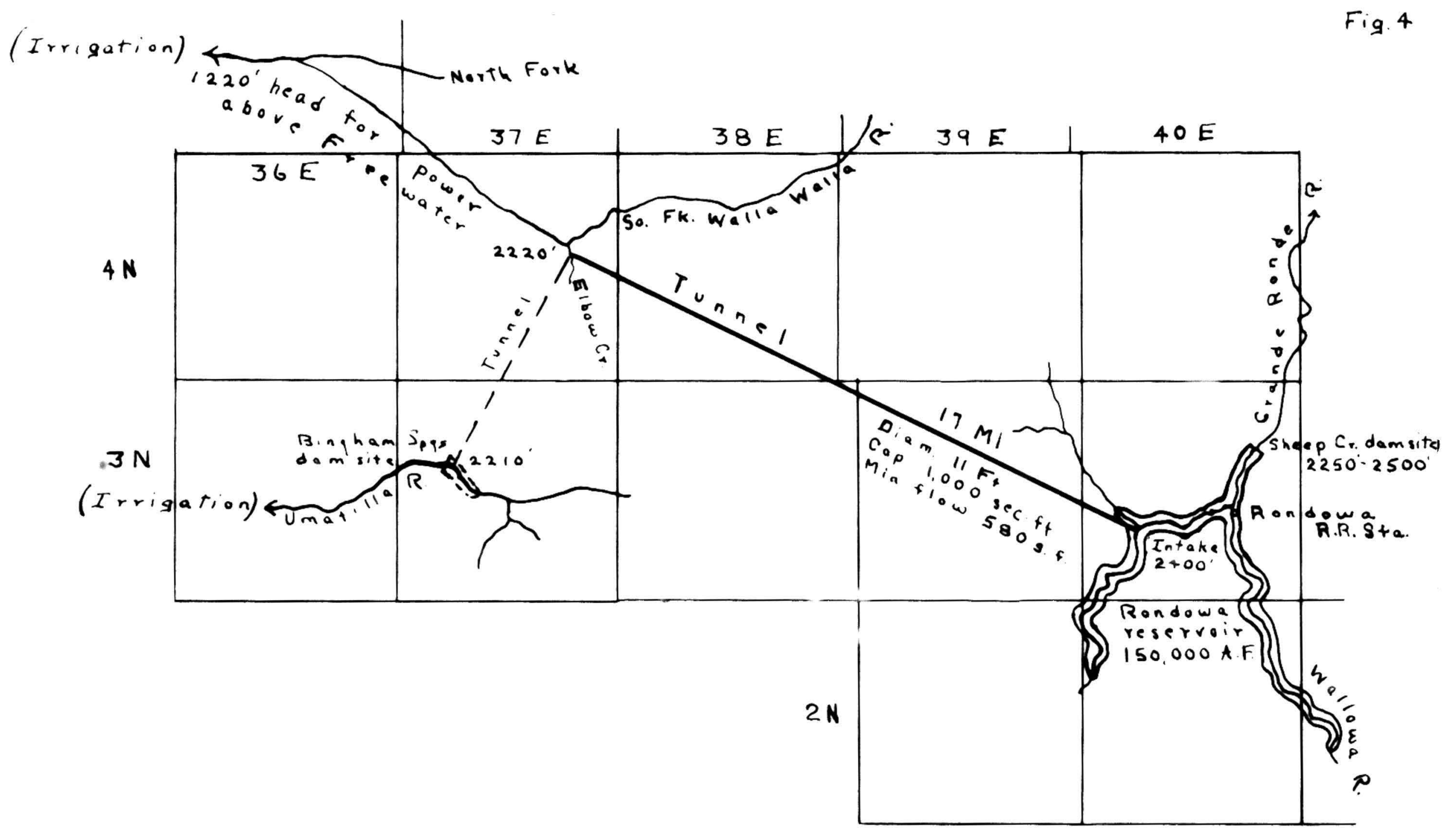

MAP OF SECTIONS OF GRANDE RONDE WALLA WALLA AND UMATILLA RIVERS SHOWING A PLAN FOR DIVERSION FOR POWER AND IRRIGATION 


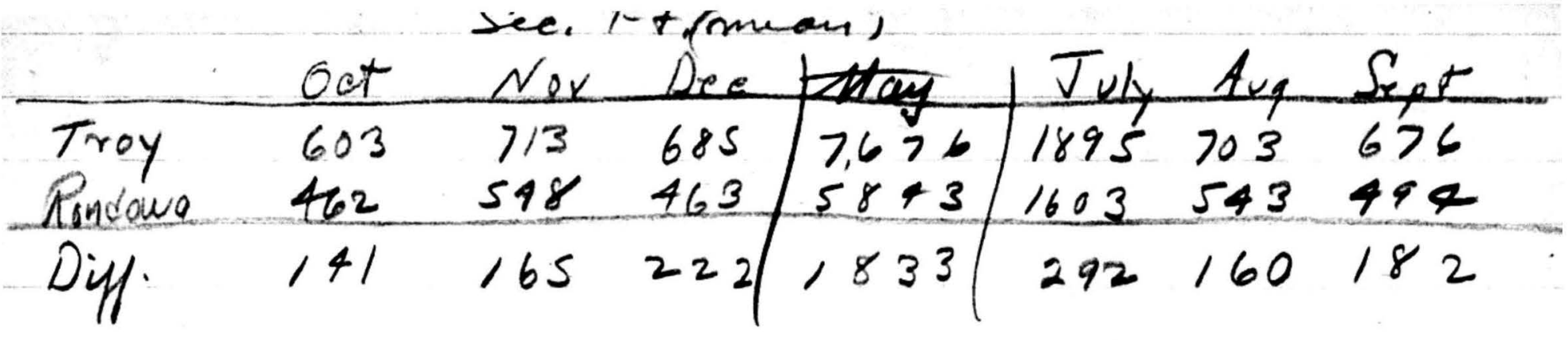

Gr Ponde ai Rourowy Unuba $R$

$$
\begin{array}{ccc}
1960 & 305 & \text { fuh } 51928 \\
1500 & 268 & 11 \\
732 & 206 & 29 \\
1740 & 318 & \text { maveh } 11,1930
\end{array}
$$




$$
\text { Comments }\left[\begin{array}{c}
\text { COMGERVATION DIVISION } \\
\text { GEOLOGICAL SURVY } \\
\text { OEC } 211953 \\
\text { PORTUND, OREGON } \\
\text { BECEIVED. NOTED, }
\end{array}\right]
$$

Thare nad the report, muir comments:

1. Cu pages 1 and 5-- and a crapee rithe pores ane refouces te the jeans in the Wallowa

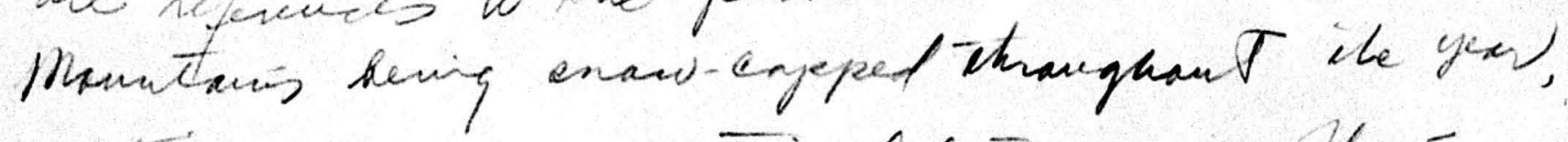
nevating in a move sastaine late-surnos Wallahar thin than in thande Mrade thin atone the mount of the Wallowa P. \& hinel in the Walloura Prie calley for many years, and as 2 reacl, the

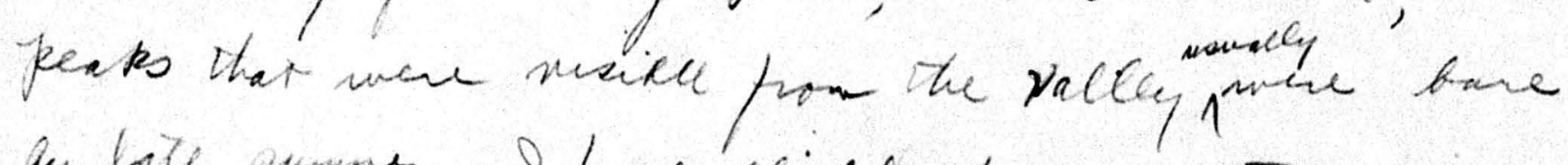

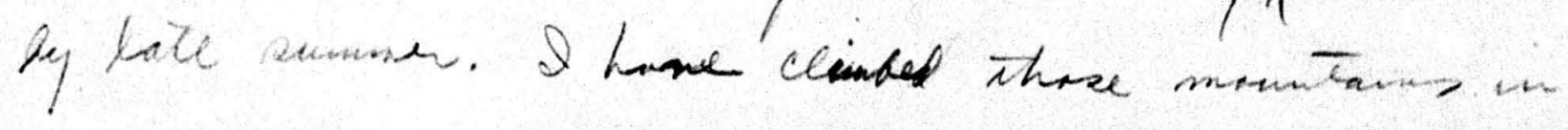
raning glare

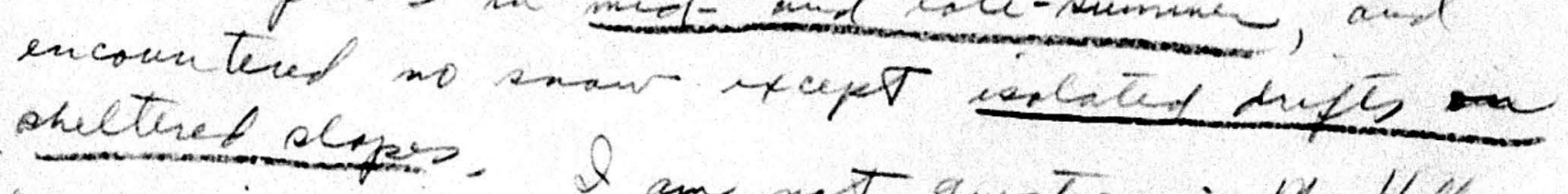
pot conparion \& whe it am nat quation; M. Helland's

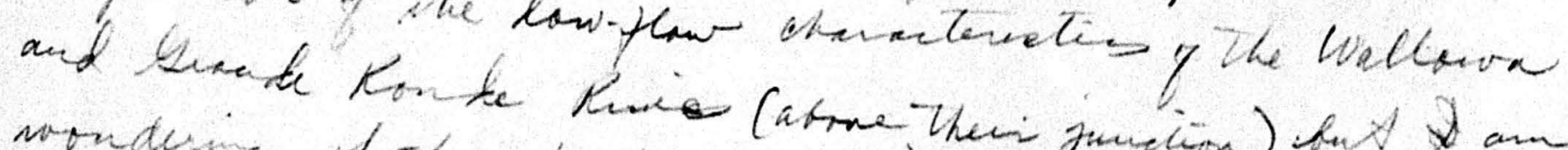

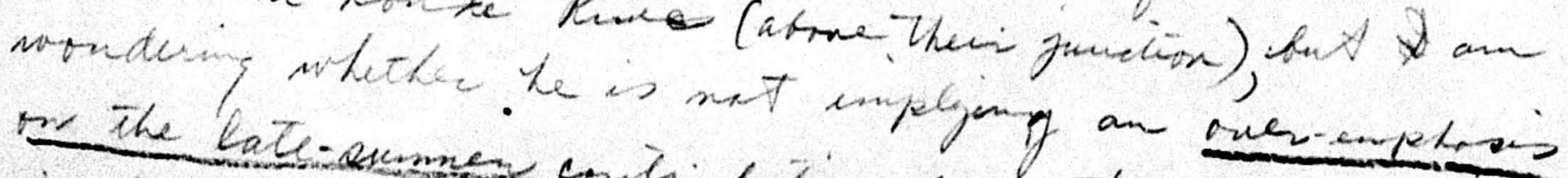

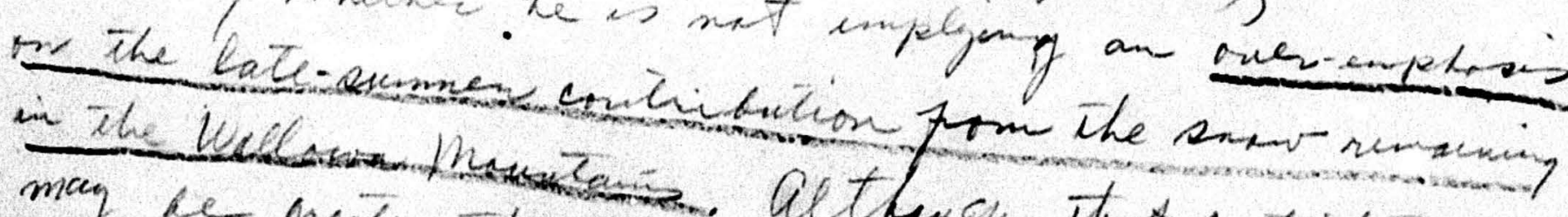

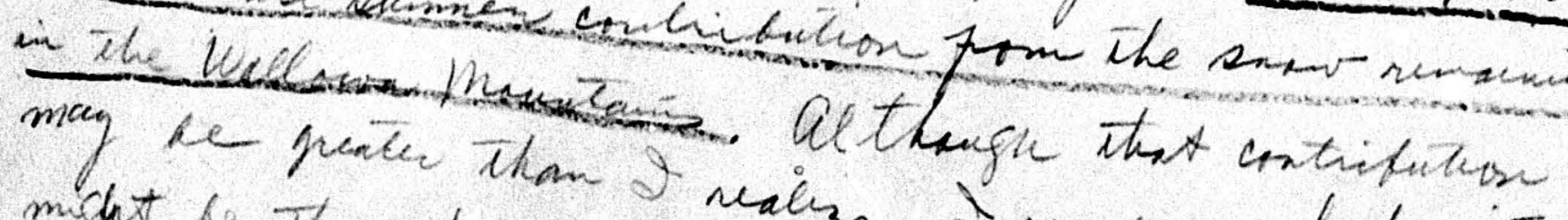
may be prenter than of naize, of wower whether it might be that the Wulawa Rine hain s more aropptine

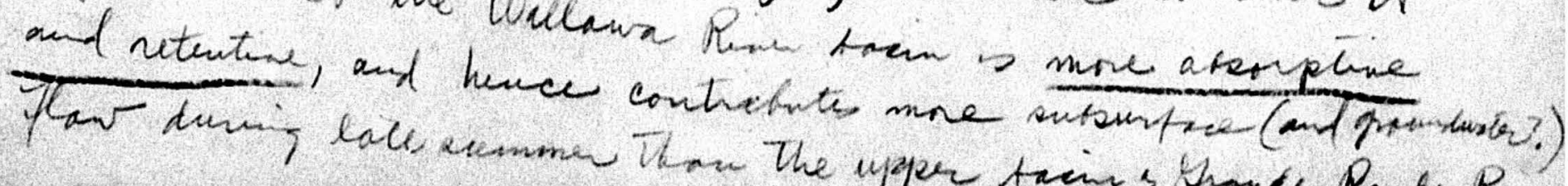
Thar dumi, lale aremmer than the upper tacing thande Rorste Riar. 
2. Wruedut it be an abvantare to plat on the map the gaging stations hided on page 7 , at leat the ackie stacions. If bath active and inache stakoss whe plattel, a kitingurehing reymbal caned ac weel.

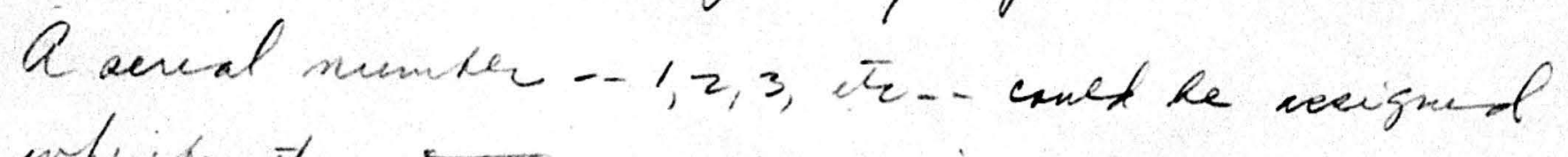
whinity the staterns caned he identified on the map. 3. L the miktley yeges a statementis make to the effert that sare land "may be recivin, too much wateo for eptimund reakts, and that a emaller smpply for there lants would gine better neults." What is meant, ipename, is that there is penty y wete and the irigators suijoly apply too murch." That caned ac concited by the exervice of tetler juggment on the pats of the famer, withent any elepes

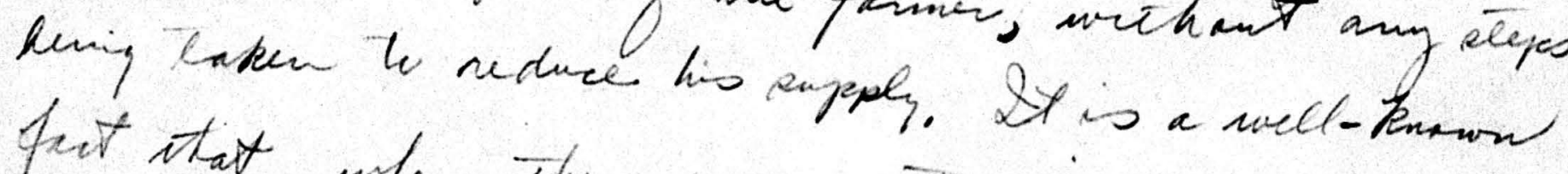
fort Ntat, when there is no sioniction on the wee 8 water, the famen tends to apply more than he nuss, flentions to the ditriment is tis land,

$*$ Preceisily
RoHt

C.N. Bue

$12-1-53$ 
commiesionens

T. H. DANFIELO, CMAIMMAN Fontlano

AnTHUN $w$. schaupr. Mannen KLAMATH FALL

MERLE R. CHESSMAN, MEmBEn Astomia

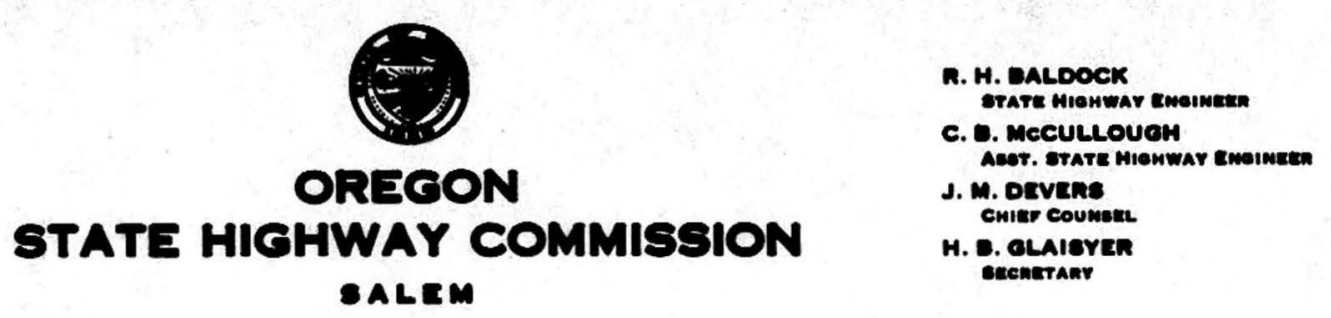

Apr11 13, 1946

D. S. Departinent of the Interror

Ceological Surver

214a 01d U. S. Courthouse

520 S. N. Morricon Street

Portland 4, Cregon

\section{Attent10n: Mr. R. O. Helland}

Dear Mr, Helland:

Complyins with your request of April 11 for plan and prof12 of the hichwar botwecn Milton and Athena, wo axe nallIns you today, under separate cover, prints of our wap fron Athena to Washington State IIne, scale $1^{\circ}=400^{\circ}$, and two proIles corering this section.

The propile arawing No. 4C-20-1 has not been serdsed to show the new work in the south iriten section. The profl1e drawing No. 9 -13-13 1 the profile of tho pevised scotion from Station $4^{+22.80}$.

There fll be nd hinge to you Nre these maps.

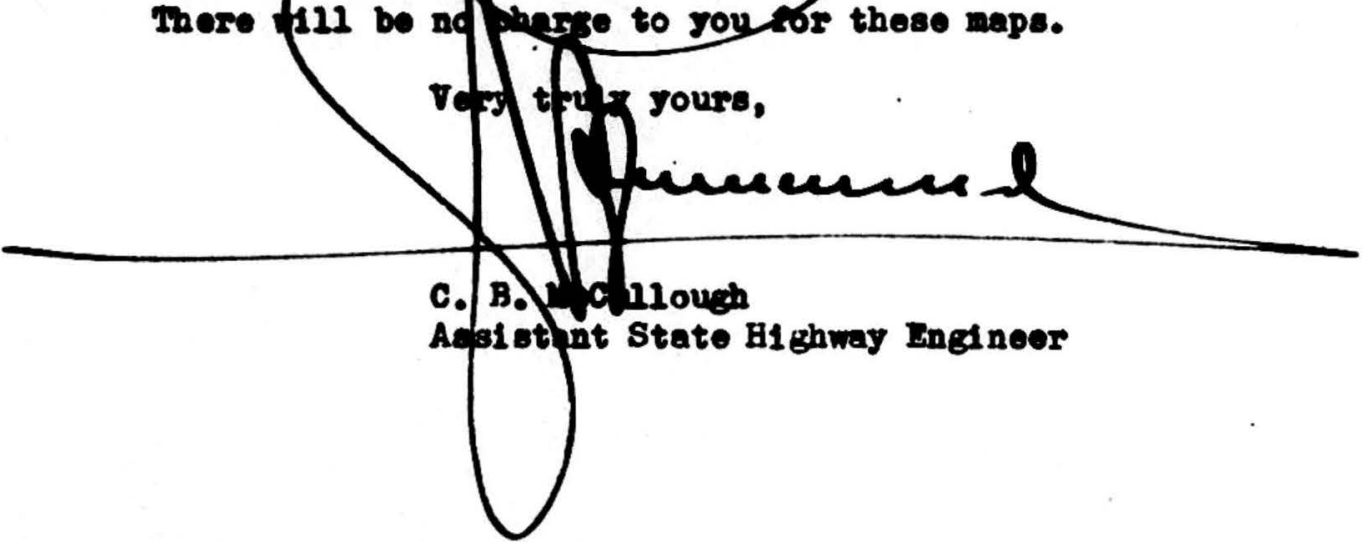




\section{2 old V. S. Courthove. \\ Portlend 4, Oregon \\ Harch 5,1945}

Mr. F. C. Hert, Englneer,

Bureau of Reclamation,

P.0. Box 499 .

Grants Pass, Oregon.

Dear Mr. Harts

Thank you for your letter of March 3, 1945, releting to proposed diversions from Grande Ronde RIver for 1 rri gation: Your letter arrives in sufficient time so that rull use can be made of the Information therein, which is much ep preclated.

Very truly yours,

R. O. HELLAND, Hydraulic Eng Ineer. 


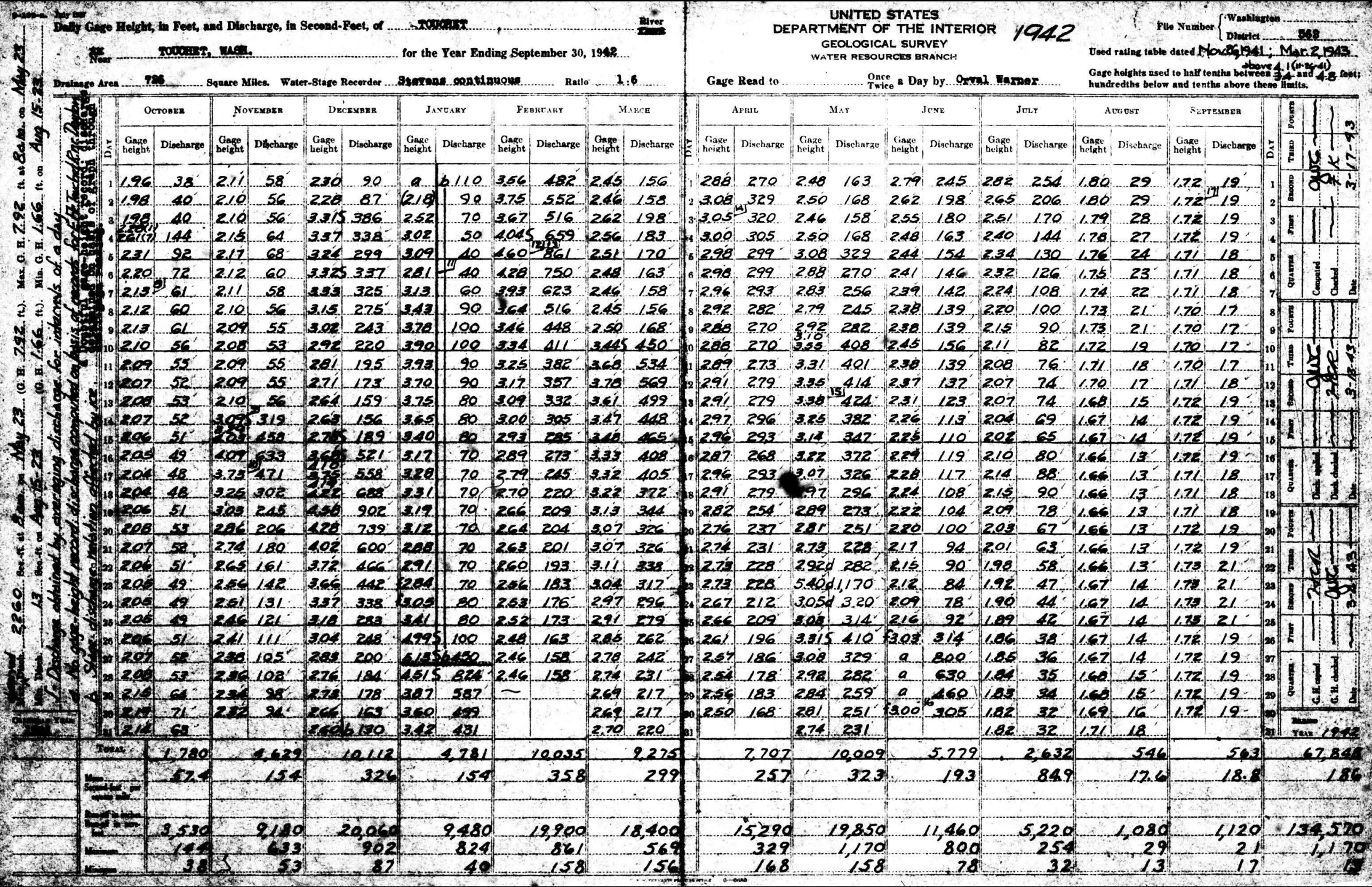




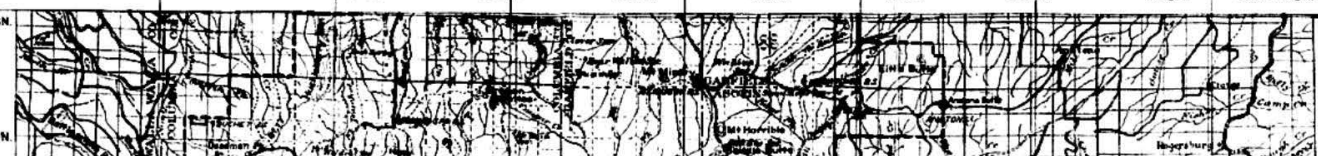

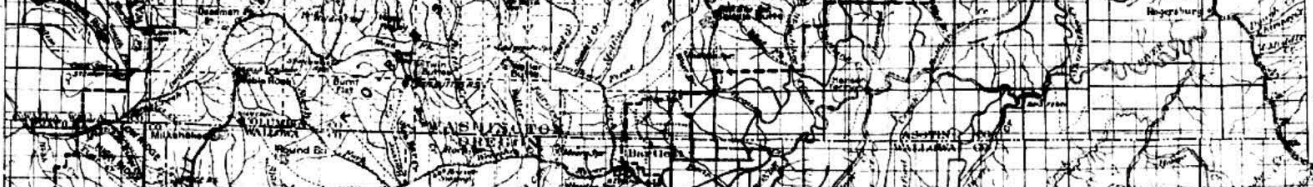

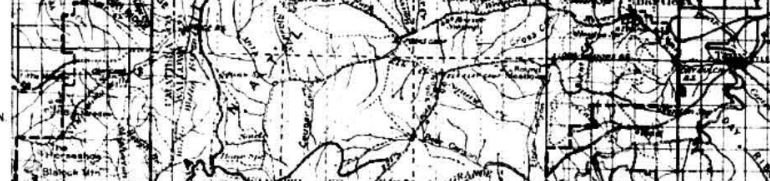

$-4,2$

4 s.

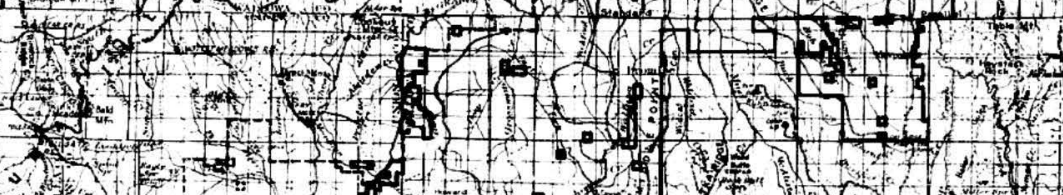

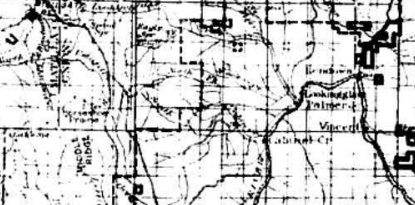

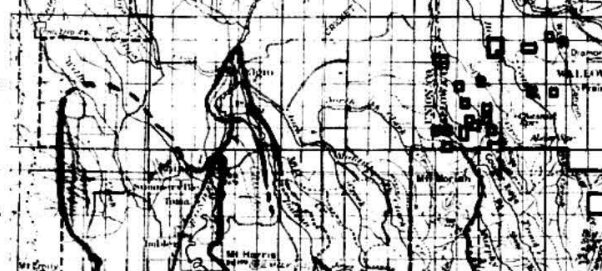

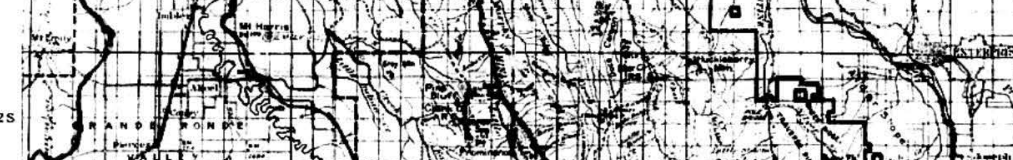
4
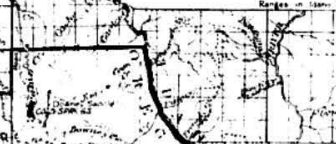

iog 100
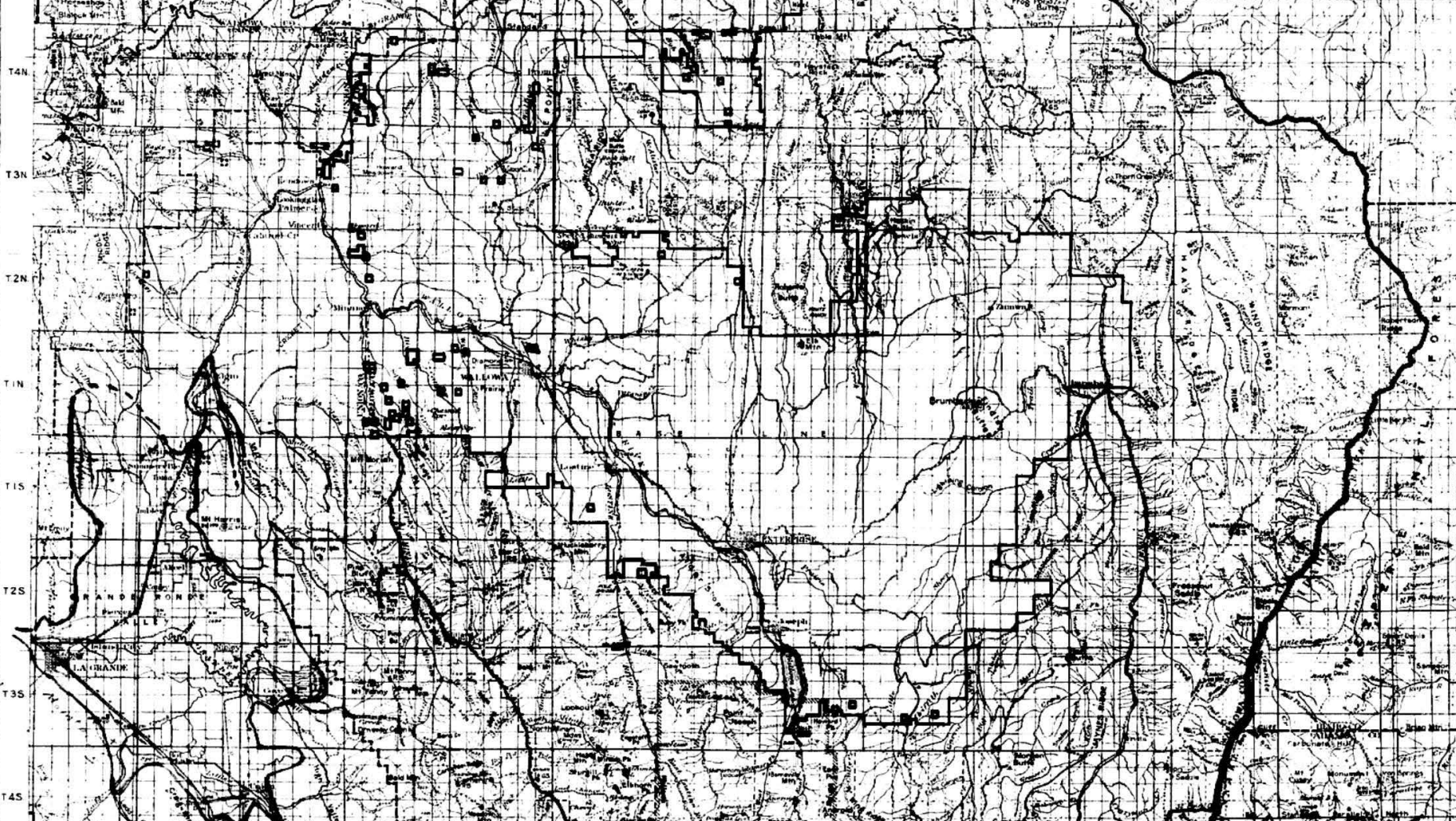

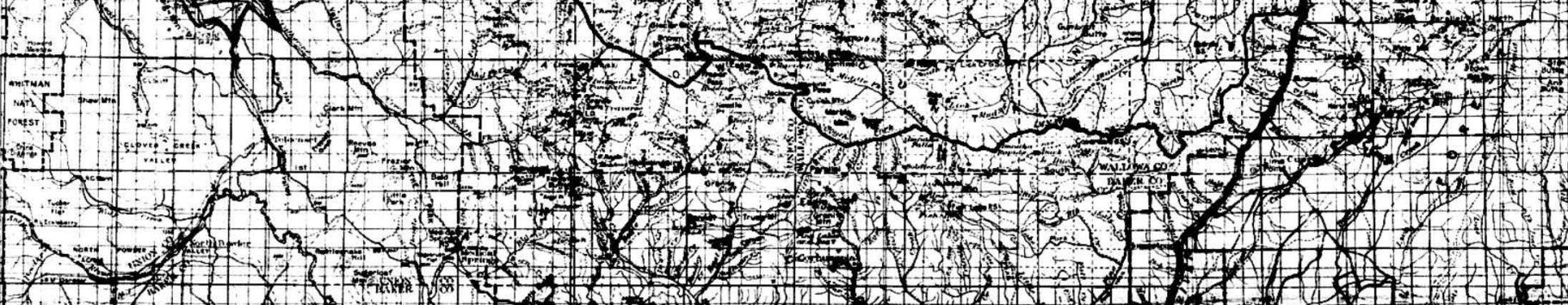

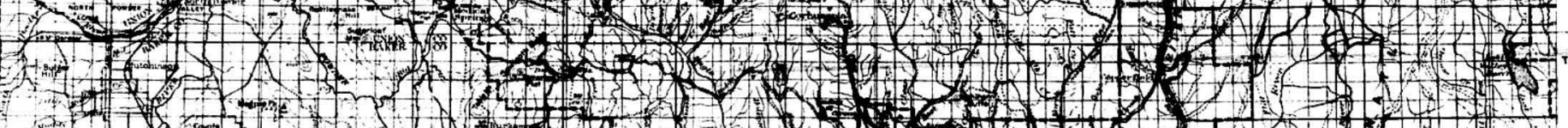

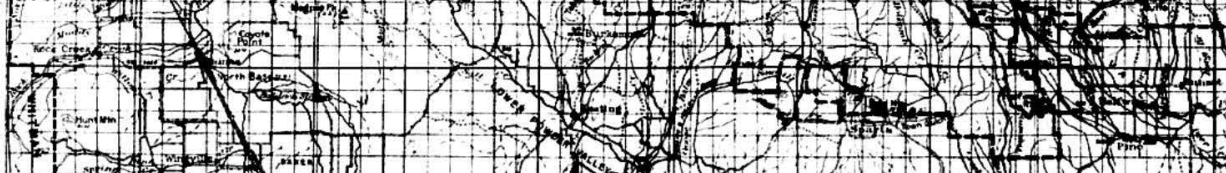

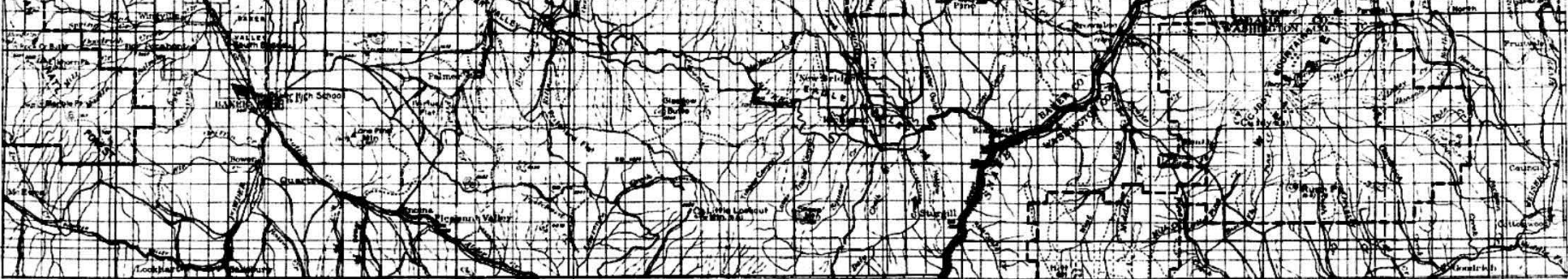




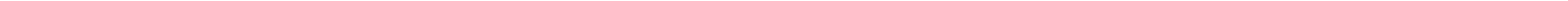




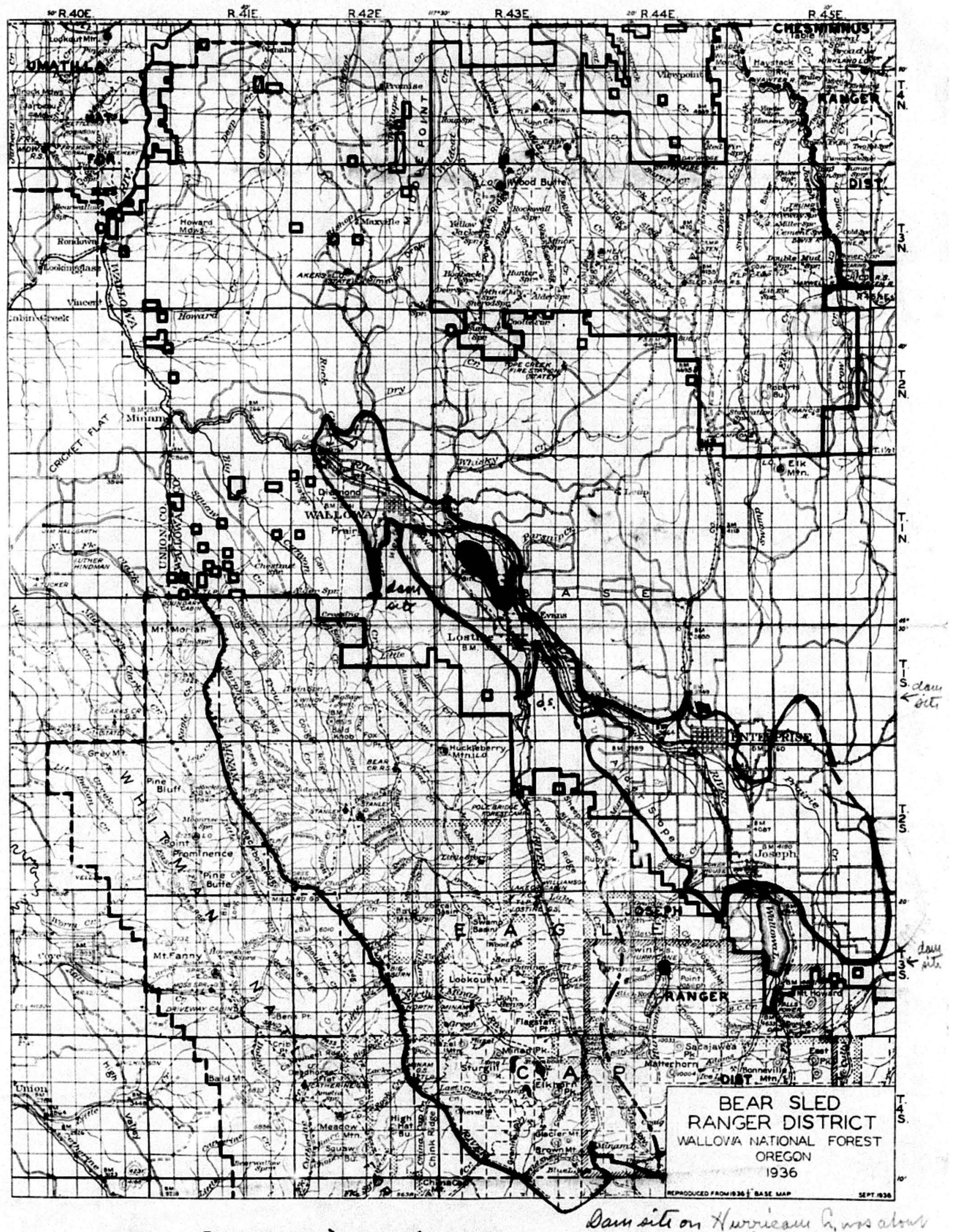

1 mile klow Thorte $h$, ans / mil dom

7 avio $a$, a $100-b$ ea

10 to is lherurases $A$ F 


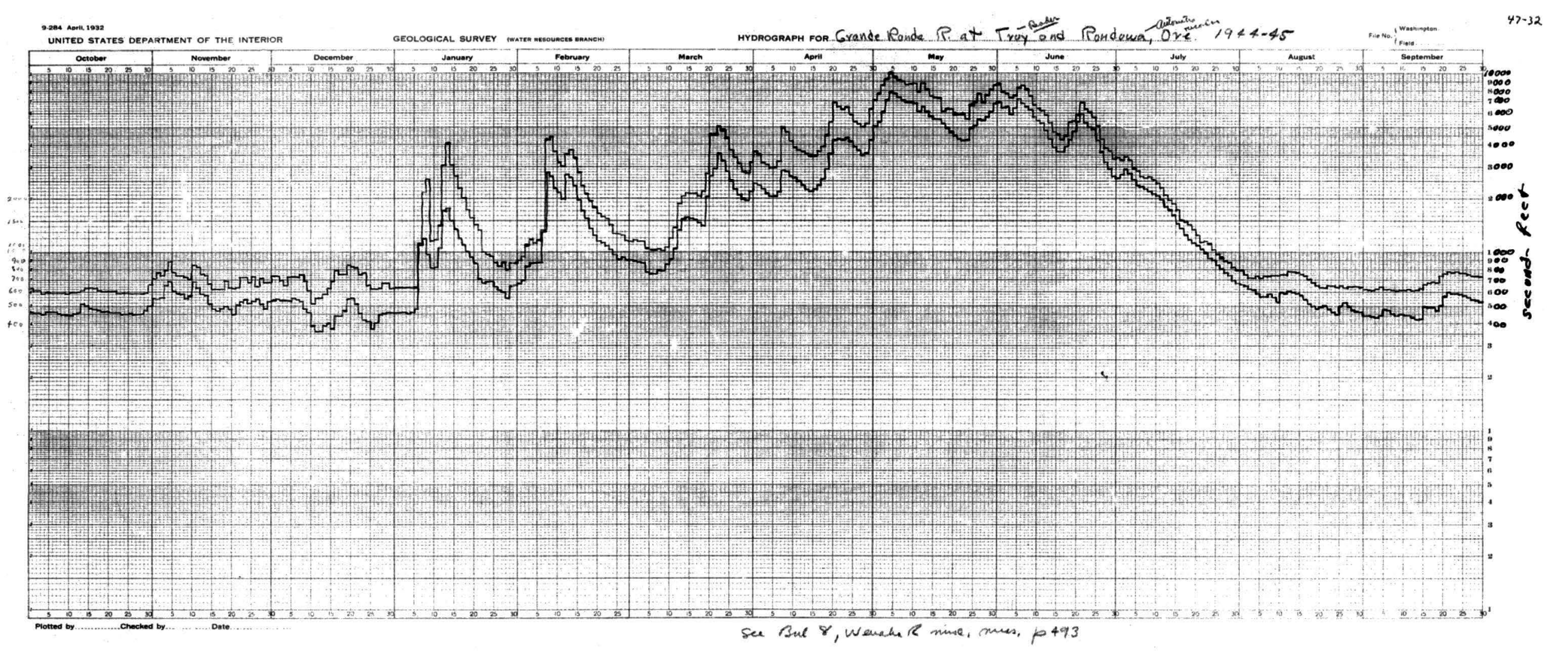

